\title{
O SOFRIMENTO NO TRABALHO ENTRE SERVIDORES PÚBLICOS: UMA ANÁLISE PSICOSSOCIAL DO CONTEXTO DE TRABALHO EM UM TRIBUNAL JUDICIÁRIO FEDERAL
}

DANIELA SANCHES TAVARES

Dissertação de Mestrado apresentada ao

Departamento de Saúde Ambiental da Faculdade de Saúde Pública da Universidade de São Paulo para obtenção do grau de Mestre.

Área de concentração:

Saúde Ambiental

Orientadora: Profa. Dra. ANA ISABEL B.B.

PARAGUAY

São Paulo

2003 
Autorizo, exclusivamente para fins acadêmicos e científicos, a reprodução total ou parcial desta dissertação, por processos fotocopiadores.

Assinatura:

Data: 


\section{RESUMO}

\section{Tavares DS. O sofrimento no trabalho entre servidores públicos: uma análise} psicossocial do contexto de trabalho em um Tribunal Judiciário Federal. São Paulo; 2003. [Dissertação de mestrado - Faculdade de Saúde Pública da Universidade de São Paulo].

Objetivo. Descrever e analisar a representação social do sofrimento no trabalho entre um grupo de servidores de um Tribunal Judiciário Federal.

Metodologia. Com base em estudo exploratório, construiu-se o roteiro de entrevista semi-estruturada, abordando os seguintes principais tópicos: a) caracterização profissional; b) descrição do trabalho; c) sofrimento no trabalho - como o define, explica e sente; d) expectativas profissionais. Foram entrevistadas 37 pessoas, dentre as quais dirigentes e servidores de 15 setores.

Resultados. A representação social do sofrimento no trabalho foi organizada em 3 agrupamentos de sentido: 1) Elementos constitutivos: injustiça no ambiente de trabalho, volume cumulativo de trabalho, não reconhecimento pelo trabalho, falta de autonomia, estagnação profissional (angústia da “estaca-zero”), opressão por parte de superiores; 2) Elementos moderadores: critérios explícitos de concessão de gratificações, relações sociais positivas no ambiente de trabalho, aprendizado no trabalho, gerenciamento adequado do volume de trabalho por parte de dirigentes, estratégias de enfrentamento (distanciamento afetivo das causas dos processos, descomprometimento com o trabalho, busca de outras oportunidades dentro da instituição por meio de contatos pessoais, estudar para ingressar em carreiras jurídicas como a magistratura, investir afetiva e intelectualmente em dimensões da vida extra-trabalho); 3) Expressões do sofrimento: medo, sentimento de auto-desvalorização, desesperança e desalento, contaminação do pensamento e do sono por conteúdos do trabalho, adoecimentos somato-psicológicos.

Considerações finais. Os resultados deste estudo evidenciam que as categorias do sofrimento no trabalho mantêm relação com a frustração das necessidades humanas e das expectativas profissionais dos servidores. Foi enfatizada a importância do conhecimento prático para as ações de promoção de saúde no trabalho.

Descritores: Saúde do Trabalhador. Sofrimento no trabalho. Representações Sociais. Psicologia Social. Saúde Mental e Trabalho. Saúde Ocupacional. Serviço Público. 


\section{SUMMARY}

\section{Tavares DS. Suffering at work among public workers: a psychosocial analysis of the}

labor context in a Federal Judicial Court. São Paulo; 2003. [Master’s Dissertation -

Public Health Faculty (Faculdade de Saúde Pública) of the Universidade de São Paulo].

Objective. To describe and analyze the social representation of suffering at work among a group of employees at a Federal Judicial court.

Methodology. Based on an exploratory survey, a semi-structured interview script was drafted so as to broach the following key issues: a) professional description; b) job description; c) suffering at work - how does the worker define it, explain it and feel it; d) professional expectations. A total of 37 people were interviewed, including managers and workers from 15 sectors.

Results. The social representation of suffering at work was organized into 3 meaning clusters: 1) Defining features: unfairness in the workplace, cumulative workload, lack of recognition for work performed, lack of autonomy, professional stagnation ("square one” anguish), overbearing bosses; 2) Mitigating features: explicit criteria for awarding gratifications, positive social relations in the workplace, learning on the job, adequate workload management by bosses, coping strategies (affective distancing from the causes of the processes, lack of commitment to the work, pursuit of other opportunities within the institution through personal contacts, studying so as to embark on legal careers such becoming a judge, affective and intellectual engagement in outside-work dimensions of life); 3) Expressions of suffering: fear, low feeling of self-worth, despair and hopelessness, contamination of thoughts and sleep by work contents, psychosomatic ailments.

Final comments. The results of this study show that the categories of suffering at work are related to frustration of human needs and workers' professional expectations. Emphasis is given to the importance of practical knowledge for carrying out healthpromotion actions in the workplace.

Descriptors: Workers' Health. Suffering at Work. Social Representations. Social Psychology. Psychosocial Environment. Mental Health and Work. Occupational Health. Public Service. 


\section{ÍNDICE}

1. INTRODUÇÃO

1.1. Funcionalismo público, modos de gestão e a saúde dos trabalhadores 8

1.2. Processo saúde-doença e o sofrimento no trabalho 13

1.3. O conhecimento prático do trabalho 19

1.4 A Teoria das Representações Sociais na Psicologia Social: considerações teóricometodológicas 20

1.5. A constituição do Judiciário como ambiente de trabalho e a saúde de seus servidores: análise da literatura judiciária e da saúde $\quad 24$

1.6. Uma breve história do Poder Judiciário Brasileiro 31

1.7. O Tribunal Regional Federal da $3^{\text {a }}$ Região 37

1.8. Alguns aspectos do regime jurídico dos servidores públicos civis $\quad 40$

1.9. A assistência à saúde dos servidores do Poder Judiciário 41

2. OBJETIVO 43

3. METODOLOGIA 44

3.1. Delineamento do projeto de pesquisa 44

3.1.1. A etapa exploratória $\quad 47$

3.2 . Composição do grupo de estudo 49

3.3. A coleta de dados 51

3.4. A análise dos dados 52

3.5. A devolutiva de resultados para os entrevistados 56

4. RESULTADOS E DISCUSSÃO 57

4.1. Caracterização da população de servidores da Instituição 57

4.2. Caracterização do grupo de estudo 60

4.3. Processo de trabalho nos setores: gabinetes e subsecretarias 66

4.3.1. Os gabinetes 66

4.3.2. As subsecretarias $\quad 70$

4.4. A Representação Social do Sofrimento no Trabalho 70

- Elementos Constitutivos do Sofrimento no Trabalho 77

- A injustiça no ambiente de trabalho 78 
- Volume cumulativo de trabalho 83

- O não reconhecimento pelo trabalho 87

- Falta de autonomia no trabalho 91

• Estagnação profissional - A “angústia da estaca zero” 98

- Opressão por parte dos superiores 99

- Elementos Moderadores do Sofrimento no Trabalho 102

- Critérios explícitos para concessão de gratificações e comissões103

- Relações sociais positivas no trabalho 105

- Aprendizado no trabalho 108

- Gerenciamento adequado do volume de trabalho por parte do desembargador e/ou dirigente

- Estratégias de enfrentamento

- Distanciamento afetivo das causas dos processos 113

- Desinvestimento no trabalho/ Descomprometimento 114

- Busca de outras oportunidades dentro da Tribunal "articular", "circular", "ser político" 116

- Estudar para prestar concursos para carreiras jurídicas (Magistratura, Promotoria, Procuradoria)

- Investir afetiva e intelectualmente em atividades extra-trabalho 118

- Expressões do Sofrimento do Trabalho 119

Medo 119

- Sentimentos de auto-desvalorização 120

- Desesperança, desalento, sentimentos negativos 121

- Contaminação do pensamento/sono por conteúdos do trabalho 122

- Adoecimentos somato-psicológicos 122

4.5. Consolidação dos resultados

4.6. A Representação Social do Sofrimento no Trabalho à luz das Necessidades Humanas e das expectativas profissionais

4.7. O conhecimento do senso comum como um sistema de pensamento formador de significados em Saúde do Trabalhador 
5. CONSIDERAÇÕES FINAIS 136

6. REFERÊNCIAS BIBLIOGRÁFICAS 138

\title{
FIGURAS
}

Figura 1 - Organização do Poder Judiciário Brasileiro 35

Figura 2 - Organograma do TRF - 3 ${ }^{\text {a }}$ Região $\quad 39$

Figura 3 - Número de servidores admitidos em cada ano de existência do TRF - $3^{\text {a }}$

Região 57

Figura 4 - População total de servidores segundo tempo de serviço 58

Figura 5 - População total de servidores segundo escolaridade 59

Figura 6 - População total de servidores segundo gênero 59

Figura 7 - Grupo de estudo segundo gênero $\quad 60$

Figura 8 - Grupo de estudo segundo escolaridade 61

Figura 9 - Presença de curso superior em técnicos e analistas 62

Figura 10 - Grupo de estudo segundo cargo de concurso 62

Figura 11 - Grupo de estudo segundo tempo de trabalho 63

Figura 12 - Grupo de estudo segundo setor de trabalho 63

Figura 13 - Grupo de estudo segundo cargo por nomeação 64

Figura 14 - Grupo de estudo segundo função gratificada 64

Figura 15 - Ocupações anteriores citadas pelos entrevistados 65

Figura 16 -Esquema sintético da Representação Social do Sofrimento noTrabalho 76

\begin{abstract}
ANEXOS
Anexo 1 - Roteiro da entrevista individual da etapa exploratória

Anexo 2 - Termo de consentimento referente à observação no local de trabalho A2

Anexo 3 - Mapa de associação - Sofrimento no Trabalho - Etapa exploratória A3

Anexo 4 - Dados de caracterização dos setores de estudo coletados na visita inicialA4

Anexo 5 - Roteiro da entrevista individual




\section{INTRODUÇÃO}

\subsection{Funcionalismo Público, modos de gestão e a saúde dos trabalhadores}

Ao definir e delimitar o termo Funcionário Público, dificuldades são encontradas. Podendo englobar grande variedade de categorias profissionais e formas diversas de afiliação e vínculo empregatício, tal termo teve seu uso formal substituído por servidor público civil, a partir da Constituição de 1988 e, depois, simplesmente por servidor público, pela Emenda Constitucional nº19, de 1998. No entanto, ambos os termos continuam a ser utilizados paralelamente a outros ainda e nem sempre se faz clara a diferença entre eles. Do concursado ao prestador de serviço ao Estado, passando pelo ocupante de cargo de confiança, todos podem ser considerados indiferenciadamente funcionários públicos ou não, a depender do critério utilizado (DALLARI, 1989; FRANÇA, 1993).

Enquanto categoria, a indefinição também existe (FRANÇA, 1993), podendo ser atribuída a definição de funcionário ou servidor público ao juiz, ao escriturário de fórum, ao Ministro, ao auxiliar técnico administrativo de um Ministério ou Secretaria. Desta forma, dentre outras questões, FRANÇA (1993) nos fala do equívoco de considerar os funcionários públicos como um grupo homogêneo pertencente à determinada classe social, comumente à classe média, estando, na verdade, também o Estado formado por diferentes classes sociais, representadas diferenciadamente no interior deste. 
Neste estudo, será considerada a conceituação apresentada por DALLARI (1989), segundo a qual, o termo mais amplo seria agente público, que é todo aquele que exerce uma função de natureza pública, mediante investidura legal. Complementa o autor que agentes públicos são todas as pessoas legalmente autorizadas a agir em nome do Poder Público, nas mais diversas situações e exercendo as mais diversas atribuições (DALLARI, 1989, p. 15). O grupo dos agentes públicos comportaria: a) o agente político (os que exercem mandatos eletivos ou que participam das decisões mais importantes e fundamentais do governo - como senadores, vereadores, presidente da República, secretários, ministros do Estado, secretários de Estado entre outros); b) os particulares que colaboram com o serviço público (aqueles que, sem fazer parte das estruturas do governo, exercem funções de natureza pública - como empreiteiras ou empresas particulares, concessionárias de transporte coletivo); c) os servidores públicos (quem trabalha para a administração pública em caráter profissional, não eventual, sob vínculo de subordinação e dependência, recebendo remuneração paga diretamente pelos cofres públicos) (DALLARI, 1989, p. 15, 16 e 17). Ainda dentro deste último grupo, o dos servidores públicos, o autor diferencia aqueles que são concursados e efetivos, dos contratados sem concurso em caráter emergencial. Segundo o autor, apenas os primeiros deveriam ser chamados de funcionários públicos, enquanto os segundos seriam servidores temporários.

Dentro desta perspectiva, onde estariam os diferentes atores sociais do Poder Judiciário? A resposta restringe-se aos magistrados; aos servidores de nível médio e superior não-magistrados; e aos servidores que ocupam cargos de confiança; sendo todos eles do âmbito federal. Os magistrados são concursados, não dependem dos resultados 
das eleições para a manutenção de seus cargos e não são temporários. Portanto, podem ser considerados servidores públicos. No entanto, a ascensão para níveis mais altos de suas carreiras depende de nomeação do Presidente da República (ver artigos 101, 104, 107, 111, 119 e123, do capítulo III da Constituição Federal) e, além disso, os magistrados detém ainda a prerrogativa de nomear e exonerar pessoas para cargos de confiança, por seus próprios critérios. Então, serão considerados como servidores públicos que gozam de especialíssimas condições e respondem por diferenciadas responsabilidades. Aqueles que ocupam cargos de confiança e não são concursados, tem seu vínculo de emprego vinculado à pessoa do juiz e não à administração pública. Ainda que haja dependência de outros para a manutenção de seus cargos, não dependem de eleições, então também são considerados servidores públicos. Já aqueles que são concursados são mais facilmente categorizados como servidores públicos. Os dois últimos têm sua relação de trabalho regulamentada pela lei nº 8112, de institui o Regime Jurídico Único dos Servidores Públicos Civis da União, das autarquias e das fundações públicas federais.

Ressalta-se ainda que o tema do funcionalismo público aparece em várias discussões, no entanto, sem o tratamento adequado e cuidadoso que mereceriam os elementos por ele envolvidos (FRANÇA, 1993).

Desde a década de 80, com o avanço da crise fiscal do Estado (ALONSO, 1999) e a preocupação de cortar gastos, o funcionalismo público vem ocupando papel de destaque entre as causas das crises do Estado no discurso neoliberal, como destaca FRANÇA (1994). Nesta direção, são precipitadamente justificadas as ações de enxugamento do quadro de pessoal no serviço público. 
No imaginário social, os funcionários públicos, as vezes, aparecem ligados a qualificativos pouco dignos de parasitismo, acomodação, oportunismo e ineficiência, tal como mostram VENEU (1990) e FRANÇA (1993). A idéia de que se oneram as contas públicas com um número excessivo de servidores também é marcante, sobretudo com contratos temporários sem concurso (DALLARI, 1989).

Por outro lado, DURAND e BELTRÃO (1994), tendo verificado que pouco se sabe a respeito da composição nacional desta categoria, mesmo em número absoluto total, apontam ser mais adequado situar este aspecto do problema da administração dos serviços públicos na má alocação de funcionários do que num suposto excesso de funcionários. Para os autores, a deficiência em dados censitários do funcionário público mantém relação com interesses na ocultação de problemas, contradições e desequilíbrios na gestão pública. Para estes autores, parece evoluir paralelamente o desmantelamento de setores da administração pública, os quais envolvem um grande contingente de funcionários, admitidos por concurso, ligados a atividades-fins e mal-pagos, e a utilização de contratações por meios de recrutamento e seleção mais flexíveis, maiores ganhos e mais sujeitas a arbitrariedades (DURAND e BELTRÃO, 1994). Este e outros aspectos decorrem do modo de gestão de órgãos públicos.

Por modo de gestão adota-se a definição de CHANLAT (1996): conjunto de práticas administrativas colocadas em execução pela direção de uma empresa para atingir os objetivos que ela tenha se fixado, compreendendo a organização do trabalho, a natureza das relações hierárquicas, o tipo de estrutura organizacional, o sistema de avaliação e controle dos resultados, as políticas de gestão de pessoal e os objetivos, valores e filosofia da gestão. 
Para CHANLAT (1996), o serviço público, sobretudo aquele relacionado aos serviços sociais, à saúde e à educação, poderiam ser classificados no modo de gestão tecnoburocrático, no qual se encontra: forte hierarquia, divisão do trabalho parcelada, presença de normas e padrões formais, grande importância atribuída aos especialistas, controles sofisticados, canais de comunicação entre os diferentes níveis hierárquicos inexistentes ou precários, centralização do poder, fraca autonomia para os cargos hierarquicamente inferiores, limitação na expressão. A ação humana neste tipo de organização é bastante limitada pelas normas existentes, ficando o trabalhador impedido, muitas vezes de responder às demandas ou situações inesperadas, que não foram previstas na concepção. CHANLAT (1996) sintetiza esta questão na seguinte idéia: “fazer bem o que se tem que fazer ainda que impedido de fazê-lo”.

Algumas questões já foram levantadas a respeito das formas de repercussão do trabalho nas instituições públicas na saúde de seus agentes. A rigidez normativa, as pressões e a desvalorização do funcionário público podem formar um conjunto propiciador de problemas de saúde nos funcionários, tais como problemas cardiovasculares, fadiga crônica, insônia e úlceras (CHANLAT, 1996).

A seguir explicita-se qual a concepção de saúde que é ponto de partida deste estudo, bem como o referencial teórico que o suporta. 


\subsection{Processo saúde-doença e o sofrimento no trabalho}

Como alicerce teórico sobre o processo saúde-doença, utiliza-se elementos da concepção do processo saúde-doença da Medicina Social, representada por LAURELL e NORIEGA (1989); elementos da discussão sobre o conceito de saúde promovida por DEJOURS (1986) e a concepção de saúde e de sofrimento de SAWAIA (1994 a,b,c).

O homem é um ser histórico-social, que constrói, transforma a sociedade em que vive e é moldado por ela, num movimento dinâmico e indivisível. Assim, nosso objeto de estudo é antes a inter-relação entre ambos do que a influência de um sobre o outro. Isto implica em recusar a dissociação entre indivíduo e sociedade na explicação de fenômenos ocorridos na vida das pessoas.

A saúde é um dos produtos deste movimento dinâmico e indivisível homemrealidade exterior. O homem, enquanto unidade biopsicossocial, responde globalmente aos acontecimentos em sua vida. Estes acontecimentos são dependentes, fundamentalmente, do modo de vida numa determinada época, sociedade, grupo e comunidade. Os modos de vida são determinados socialmente e o homem vai se adaptando plasticamente por meio de mudanças nos processos biológicos e psíquicos. Na concepção de LAURELL e NORIEGA (1989), não se trata de uma adaptação na concepção fisiológica, em que o organismo retorna ao estado normal após adaptar-se, mas trata-se de uma adaptação para permitir a sobrevivência, com conseqüências muitas vezes inespecíficas, insidiosas e imensuráveis na totalidade que representa o homem. 
Tal processo de adaptação, segundo LAURELL e NORIEGA (1989), converte-se em padrões de desgaste determinados pelas condições de vida do grupo social de pertença, não negando, entretanto, a possibilidade de respostas adaptativas atípicas, sobretudo no âmbito psíquico, em que a diversidade constitutiva é anterior.

Neste momento, retoma-se a discussão promovida por DEJOURS (1986) sobre o conceito de saúde, segundo o qual um conceito único e estático para o que seja a saúde, tal como o adotado pela Organização Mundial da Saúde ${ }^{1}$ não encontra correspondência na realidade, constituindo-se mais como um objetivo a ser buscado do que a um estado real. Com isso, destaca o autor a dinamicidade da saúde enquanto processo e não estado fixo, idéia segundo a qual a saúde de uma pessoa se forma e se transforma continuamente, num processo dinâmico de interação circunstancial entre aspectos biológicos, psíquicos, sociais e culturais.

Salienta-se a seguir algumas premissas a respeito da dimensão psicossocial do processo saúde-doença, tal como apresentadas na Psicologia Social por SAWAIA (1994 a,b,c) e adotadas neste estudo.

SAWAIA (1994c) salienta a característica de mediação de aspectos psicossociais em contraposição a visões reducionistas sobre uma relação causal entre o organismo e fatores externos ao mesmo (seja numa doença infecciosa, seja no adoecimento mental).

O homem é um animal simbólico que reage frente aos significados que ele próprio constrói historicamente, e não às coisas em si. Estes símbolos mudam o

\footnotetext{
${ }^{1}$ Saúde é o estado de completo bem-estar, físico, mental e social, e não somente a ausência de doença ou enfermidade (Hogarth, 1975).
} 
ambiente, a natureza, a sociedade e inscrevem-se no biológico (SAWAIA, 1994c, p. 106).

Os significados atribuídos em decorrência de valores culturais, familiares, pessoais cumprem papel de mediadores, pois atuam na determinação das necessidades, desejos, expectativas das pessoas e, portanto, na determinação do que é saúde e das práticas desenvolvidas pelas pessoas no seu cotidiano com vista à promoção dela, a saúde. A saúde estaria condicionada à necessidade humana de transformar continuamente o mundo à sua volta, imprimindo-lhe significados particulares, construídos social e individualmente.

Nesta concepção, a saúde é uma questão eminentemente sócio-histórica e, portanto, ética, pois é um processo da ordem da convivência social e da vivência pessoal (SAWAIA, 1994 b, p. 157), deixando de ser não doença ou estado de pleno bem-estar, para tornar-se possibilidade objetiva e subjetiva de estar sempre buscando este estado, $e$ o direito à saúde se revela como direito de ter essa possibilidade SAWAIA (1994c, p. 109 e 110).

Este direito pressupõe as diferenças entre grupos e indivíduos, que determinam a saúde e o bem-estar procurados por grupos ou indivíduos.

Saúde é a possibilidade de ter esperança e potencializar esta esperança em ação. Promover a saúde equivale a lutar contra todas as formas históricas de violência do corpo e da alma, geradoras de servidão e heteronomia. (SAWAIA, 1994b, P. 157).

O trabalho, enquanto necessidade humana, aparece como um dos elementos mediadores desta relação entre homem e sociedade, por meio do qual este homem realiza ações sociais, regulando-as de acordo com possibilidades e necessidades percebidas nele 
próprio e em seu ambiente, ou é impedido de tal feito, em decorrência de uma organização do trabalho rígida e hetero-determinada.

MORIN (2001) constata que a organização do trabalho deve oferecer aos trabalhadores a possibilidade de realizar algo que tenha sentido, de praticar e de desenvolver suas competências, de exercer seus julgamentos e seu livre-arbítrio, de conhecer a evolução de seus desempenhos e de se ajustar.

Sobre este último aspecto, o ajustamento, é preciso lembrar que o trabalhador precisa não só ajustar-se, mas também ajustar a tarefa e as condições de realização da mesma às suas necessidades, seus desejos, suas capacidades e seu modo de ser (SATO, 1991).

Toma-se por ética algo que se define no interior das relações sociais historicamente dadas (HELLER, 1972). Isto significa dizer que alguém ou algo só é ético em relação ao outro, em relação à sociedade e que, esta, sendo transformada continuamente, transforma também os parâmetros do que é ser ético. Tendo como centro a esfera das ciências, não se pensa ética enquanto elemento externo a ser introduzido na pesquisa, mas se considera que a ética se apresenta na própria concepção do sujeito de estudo, o homem, enquanto ser de relação, portador de uma história, de vontades, desejos, necessidades, os quais devem ser respeitados. A ética está presente na intencionalidade da construção teórica.

A atividade científica não é neutra, mas sim determinada por injunções históricosociais e inevitavelmente permeada por sistemas de crenças e valores socialmente partilhados em seus pressupostos, escolhas de objetos e temas, não só atribuíveis ao 
pesquisador e sua história individual, mas à época histórica em que se situa a pesquisa e o pesquisador (SOUSA SANTOS, 2001).

Mesmo acordado de que a intencionalidade que deve suportar toda construção teórica das ciências humanas é a emancipação do homem das condições objetivas que o subjugam e a felicidade do homem, sabe-se que não é consenso a forma pela qual esta emancipação pode se dar (CARONE, 1994)

Adota-se a posição de HELLER (1998), segundo a qual a emancipação do homem só pode se dar de maneira gradual, sendo seu espaço vital o cotidiano. O cotidiano é o espaço privilegiado das possibilidades de cada homem, porque nele a subjetividade se faz marcadamente presente.

A vida cotidiana é a vida do homem inteiro; ou seja, o homem participa na vida cotidiana com todos os aspectos de sua individualidade, de sua personalidade. Nela, colocam-se "em funcionamento" todos os seus sentidos, todas as suas capacidades intelectuais, suas habilidades manipulativas, seus sentimentos, paixões, idéias, ideologias (HELLER, 1972, p.17)

É na vivência cotidiana que o homem se apropria dos instrumentos, da linguagem e dos costumes que serão indispensáveis a sua sobrevivência e adaptação a determinado grupo, comunidade ou sociedade. É também no cotidiano que apreende a razão prática, a partir da observação e conhecimento das regras e normas do meio em que o homem se insere (CARONE, 1994). A condição para a emancipação se encontra na possibilidade e na capacidade de o homem articular a razão prática e a razão teórica na construção ativa de seu espaço vital, experimentando, modificando, adaptando a partir de suas necessidades, aspirações, desejos, ilusões. 
Para HELLER (1998), a satisfação das necessidades de auto-determinação não significa liberdade absoluta e autonomia completa e nem que o homem esteja livre das determinações do contexto em que se insere, mas sim que ele deve poder atuar nesse contexto a partir do reconhecimento de suas necessidades, aspirações, desejos e ilusões. Para tal, utiliza a expressão enfrentar o contexto.

Segundo HELLER (1972), quando as formas da vida cotidiana se cristalizam, não deixando ao indivíduo a necessária liberdade de movimento, o indivíduo fragmentase em seus papéis, perdendo sua unidade enquanto ser humano.

Parece ser a partir disso que SAWAIA define o sofrimento enquanto objeto de estudo da psicologia social da seguinte forma: a fixação do modo rígido de estado físico e mental que diminui a potência de agir em prol do bem comum, mesmo que motivado por necessidades do eu, gerando, por efeito perverso, ações contra as necessidades coletivas e, conseqüentemente, individuais (SAWAIA, 1994a, p.50).

Adotar o sofrimento enquanto elemento central deste estudo, significa reportar-se à esfera da vivência pessoal como fonte do conhecimento sobre o processo saúde-doença (OLIVEIRA, 2000), possibilitando situar a pessoa no centro de produção do conhecimento. Além disso, também privilegia o aspecto dinâmico dos mecanismos de adaptação e resistência elaborados e aplicados no cotidiano como forma de preservar a saúde e a integridade psicológica e social. Assim, não é a doença, mas aquilo que o homem identifica como fonte de sofrimento no cotidiano de trabalho o foco do estudo. 


\subsection{O conhecimento prático do trabalho}

Diferenciando o conhecimento da estrutura, normas e regras formais daquele conhecimento construído no cotidiano, baseado na vivência das situações reais (SPINK, 1996; CHANLAT, 1996), ressalta-se que interessa aqui este conhecimento formado no encontro entre as condições objetivas de trabalho, as regras institucionais, as tarefas reais e os diferentes atores sociais.

Ao se conceber a saúde, no sentido geral, como resultado do exercício da cidadania, pelo qual se pode viver exercendo direitos, deveres e responsabilidades em todos os espaços da vida social, inclusive no trabalho, no que diz respeito à produção de saberes sobre o trabalho, torna-se essencial a reabilitação do conhecimento do trabalhador enquanto conhecimento válido na identificação dos problemas do ambiente de trabalho, tanto no âmbito da qualidade do trabalho quanto da saúde dos trabalhadores.

No cotidiano é que se constrói um corpo de conhecimentos a respeito dessa realidade compartilhada de trabalho, que permitirá um norte nas ações do dia-a-dia, com fins de cumprir as atribuições, contornar as dificuldades, bem como buscar o equilíbrio no dispêndio de energia e esforços, entendidos aqui não somente pelo aspecto físico, mas também mental.

Este conhecimento é regido por uma lógica própria, podendo encontrar pontos de tangência e de distanciamento com a lógica e os achados do conhecimento científico e utiliza-se de métodos próprios - vivência, observação e troca de informações (SATO, 1995, p.56). 
SATO (1991), em dissertação de mestrado sobre o significado do conceito "trabalho penoso" para motoristas de ônibus urbano, propõe a busca do conhecimento prático do trabalhador enfocando as representações sociais. Afirma a mesma autora que a teoria das representações sociais fornece elementos para refletir sobre a funcionalidade, a dinâmica e a estrutura do conhecimento prático, o qual engloba a visão do trabalhador sobre a realidade do seu trabalho (SATO, 1991).

As práticas de trabalho não prescritas, que freqüentemente viabilizam a consecução do trabalho em condições não previstas ou incidentais ou que ainda alteram procedimentos (DANIELLOU e cols, 1989), são expressão da subjetividade dos trabalhadores.

Uma leitura que leve em conta a subjetividade dos trabalhadores é imprescindível para compreender as práticas de trabalho, pois a primeira é parte integrante da segunda. Sobretudo quando se pretende alcançar uma melhor compreensão da relação entre o trabalho e a saúde dos que o realizam.

\subsection{A Teoria das Representações Sociais na Psicologia Social: considerações teórico-metodológicas}

Com a noção de Representação Social, introduzida por MOSCOVICI, em 1961, o mesmo pretendeu redefinir os problemas e conceitos da psicologia social (MOSCOVICI, 1978), numa perspectiva integradora da estrutura social e do sujeito na 
construção da realidade, superando as concepções individualizantes da psicologia social da América do Norte e Grã-Bretanha (FARR, 2000). Considerado como predecessor da noção de representação social, o conceito durkheimiano de representação coletiva trouxe uma contribuição da sociologia à construção de uma forma sociológica de psicologia social (FARR, 1994).

Além disso, visou resgatar o conhecimento do senso comum, enquanto sistema de pensamento e conhecimento racional (MOSCOVICI e MARKOVÁ, 1998)

A teoria das representações sociais tornou-se um campo fértil de pesquisa empírica e passou a ser um ponto de partida para diferentes enfoques teóricos e metodológicos.

Aqui está se adotando a perspectiva da psicologia social, representada por Jodelet, cujo conceito de Representação Social é:

As representações sociais constituem modalidades de pensamento prático orientados para a comunicação, a compreensão e o domínio do contexto social, material e de idéias. Assim, apresentam características específicas de organização de conteúdos, de operações mentais e de lógica (JODELET, 1984, p. 472).

A determinação social do conhecimento do indivíduo dá-se, através do contexto concreto em que se situam os indivíduos e os grupos, através da comunicação que se estabelece entre eles, através dos marcos de apreensão que proporciona sua bagagem cultural, através dos códigos, valores e ideologias relacionados às posições e afiliações sociais específicas (JODELET, 1984, p. 473). 
A medida em que as representações estão ligadas à comunicação, à pragmática e, portanto à ação, as práticas sociais devem ser elemento imprescindível na discussão sobre a natureza e a constituição das Representações Sociais (ROUQUETTE, 1998).

A inter-relação entre o homem e a sociedade na determinação da realidade já foi assumida como pressuposto. Retoma-se neste momento esta inter-relação, por meio da discussão sobre a natureza da influência que as representações exercem sobre as práticas sociais e vice-versa. ROUQUETTE (1998) identifica influências de naturezas diferentes entre as representações e as práticas, ou seja, embora haja uma inter-relação, não há reciprocidade. Uma forma mais apurada de descrever tal relação poderia tomar as representações como uma "condição das práticas", e as práticas como um "agente de transformação" das representações (ROUQUETTE, 1998). A influências das práticas sobre as representações constitui uma determinação objetiva, enquanto que a influências das representações sobre as práticas seriam uma coerção variável e não determinação propriamente dita (ROUQUETTE, 1998).

A representação que um grupo social tem sobre o sofrimento no trabalho pode trazer valiosos elementos para a identificação de aspectos do trabalho relacionados ao adoecimento e agravos à saúde destes, mas também, para a compreensão de comportamentos e expectativas em relação ao contexto de trabalho vivenciado, não numa lógica de causalidade, mas de compreensão de relações existentes.

Os fenômenos de representação social estão presentes nas inúmeras situações de interação social, são complexos e não podem ser apreendidos na sua totalidade. A construção do objeto de pesquisa em representações sociais parte da constatação da 
existência e relevância de tal fenômeno em determinado meio social, em direção à sua elaboração e transformação em objeto de pesquisa, no universo reificado da ciência. A construção do objeto de pesquisa é sempre uma simplificação, em que um processo complexo, abrangente e, a princípio, indivisível, passa a ser visto sob critérios de delimitação e seleção de determinados aspectos. Estes critérios são baseados em questões práticas de viabilidade e na perspectiva teórica adotada (SÁ, 1998). Assim, o sofrimento no trabalho constitui-se em um objeto da presente pesquisa, na medida em que se verificou a sua existência e relevância no universo consensual do grupo social em questão (ver item referente à etapa exploratória no capítulo "Metodologia”), sua pertinência em relação ao referencial teórico adotado e adequação ao problema de estudo.

Em relação à sua sócio-gênese, o sofrimento no trabalho, enquanto objeto de representação entre funcionários públicos do setor judiciário, poderia ser classificado no campo de eventos específicos (WAGNER, 1998), os quais são sempre o produto de um processo explícito da avaliação social de pessoas, grupos sobre um objeto comum de relevância prática e funcional para o grupo (WAGNER, 1998). Tais representações têm uma história limitada no tempo e sua validade diz respeito à população estudada. Um aspecto importante na formação desse tipo de representação social (de um evento específico, com um recorte limitado temporal e espacialmente) é o papel da confrontação de posições dos diferentes atores sociais, da troca de experiências, na conversação diária, processos estes que originam um discurso coletivo sobre o objeto em questão. O que faz com que se mobilizem tais recursos para a formação da representação 
social é a necessidade prática (WAGNER, 1998; SATO, 1993), que, no caso, é conhecer os diferentes espaços institucionais e caracterizá-los do ponto de vista das condições melhores ou piores de trabalho, parâmetros coletivos de bem-estar, bem como buscar melhor ajuste entre o trabalho tal como se apresenta e as necessidades e características de quem o executa por meio de ações adaptativas (SATO, 1993), identificar situações problemáticas e formas de manejá-las (SATO, 2002).

A análise e a compreensão das representações sociais de um determinado objeto se fazem a partir de categorias emergentes da teoria do senso comum e não moldando seu conteúdo por meio de teorias do conhecimento científico ou outro tipo de conhecimento externo ao contexto que a forma (SATO, 1992).

\subsection{A constituição do Judiciário como ambiente de trabalho e a saúde de seus servidores: análise da literatura judiciária e da saúde}

O Poder Judiciário têm sido alvo de análises e críticas devido à incapacidade que tem demonstrado em atender às crescentes demandas sociais à Justiça (BRITO, 1995). A falta de efetividade na distribuição de justiça tem provocado reações da mídia, dos movimentos populares e da população em geral (SADEK e ARANTES, 1994) e se 
constitui no principal aspecto do que se convencionou denominar "Crise da Justiça” ou “Crise do Judiciário"” (SADEK, 1995).

SADEK e ARANTES (1994) demonstraram a defasagem entre processos que entram e processos que são julgados, o que significa conseqüente acúmulo de processos: tomando-se como base todo o Brasil, o número de processos julgados na primeira instância em 1990 correspondeu a 57,8\% dos processos que entraram neste mesmo ano, também na primeira instância.

Relaciona-se a ineficiência da Justiça à sua estagnação e incapacidade de mudar. Assim, o apego ao passado e a resistência à mudança seriam alguns dos principais motivos do descompasso entre o Poder Judiciário e as necessidades e exigências da sociedade contemporânea (DALLARI, 1996, p. 7).

Frente a tal panorama, como seriam as condições de trabalho experimentadas pelos integrantes de instituições do Poder Judiciário? E ainda, quais seriam as repercussões à saúde das pessoas que trabalham nestas instituições? Ressalta-se que esta tem sido uma preocupação dos profissionais dos serviços médicos de diferentes instituições do Poder Judiciário.

${ }^{2}$ SADEK e ARANTES (1994), ao mapearem a Crise do Judiciário, identificam três áreas de problemas, que são: a crise institucional, a crise estrutural e a crise relativa aos procedimentos. A crise institucional diz respeito ao papel do Poder Judiciário frente aos outros poderes, sua independência e autonomia. A crise estrutural se refere à estrutura de organização e atribuições das instituições formadoras do Poder Judiciário. A crise de procedimentos aponta para aspectos da lei processual. 
Para se identificar e fundamentar a relevância destas questões, foram feitos levantamentos bibliográficos focados em temas relacionados às condições de trabalho em órgãos do Poder Judiciário e à saúde dos servidores públicos do Poder Judiciário ${ }^{3}$.

Alguns breves relatos a respeito da natureza do trabalho e das suas condições de realização foram encontrados na literatura jurídica que trata da "Crise do Judiciário". Contrariamente às idéias de ócio e acomodação, as vezes relacionadas ao funcionalismo público e que também foram encontradas em estudo sobre as representações existentes acerca do funcionário público (VENEU, 1990), os órgãos do Poder Judiciário caracterizam-se pela grande carga de trabalho, considerada incompatível com o quadro de funcionários, com as condições de trabalho e com a lógica processual vigente, o que resulta na lentidão e prejuízo na prestação dos serviços à comunidade (SADEK e ARANTES, 1994; ARAGÃO, 1997; BRITO, 1995 e DALLARI, 1996).

Ao analisar os principais problemas relacionados à organização e ao funcionamento dos tribunais, DALLARI (1996) discute alguns aspectos das condições de trabalho dos juízes e dos servidores, apontando para a existência de precárias condições materiais, de equipamentos e de espaço físico, em que se realizam as atividades de trabalho.

Em estudo exploratório a respeito dos fatores relacionados à lentidão da atuação da Justiça do Trabalho do Espírito Santo, ARAGÃO (1997), após entrevistar 30 pessoas, entre servidores, juízes, procuradores, advogados, representantes sindicais de

\footnotetext{
${ }^{3}$ No campo judiciário foram feitas buscas nas bases de dados da Rede Virtual de Bibliotecas do Congresso Nacional, da Biblioteca do TRF $3^{\text {a }}$ Região e da Biblioteca da Faculdade de Direito da Universidade de São Paulo.
} 
trabalhadores e prepostos de empresas, identificou, entre outros fatores, ausência de uma política de recursos humanos para juízes e servidores, carreira restrita e conseqüente desmotivação dos servidores, ausência de rodízios de função, excessiva centralização administrativa por parte dos juízes, ausência de mecanismos reguladores do poder dos juízes, instalações físicas precárias e insuficiência de recursos materiais, fluxo deficiente de informações, incompatibilidade entre o número de servidores necessários e o volume de serviço nos órgãos (ARAGÃO, 1997).

Na literatura judiciária pesquisada destaca-se a predominância de estudos que tomam como base pareceres de estudiosos do setor judiciário, juízes e desembargadores. Foi encontrado apenas um trabalho, que é o de ARAGÃO, (1997), o qual foi comentado acima, que buscou a opinião de servidores como fonte de informações.

Quanto às repercussões à saúde dos funcionários, fatores semelhantes aos levantados na literatura judiciária como problemáticos do ponto de vista da eficiência foram descritos como causa de sofrimento pelos trabalhadores, por um estudo exploratório desenvolvido pelo Centro de Referência em Saúde do Trabalhador do Estado de São Paulo - CEREST/SP, cujo objetivo foi avaliar as condições de trabalho em vara pertencente a uma Seção Judiciária da Justiça Federal (CORDEIRO, GARBIN e cols, 2000). Foram relatados: sobrecarga de trabalho, impossibilidade de planejamento de carreira, existência de comissões e promoções a cargos de confiança cujos critérios não eram explícitos aos funcionários, presença marcante de desvios de função e poder excessivamente centralizado na figura do juiz. Tais características foram citadas como dificuldades na realização do trabalho, fonte de desgaste, e motivo de frustrações e 
aborrecimentos para estas pessoas, que ingressam no Poder Judiciário com expectativas de desenvolvimento profissional em sua área de conhecimento, já que grande parte deles é bacharel em Direito ou estudante da área. Além disso, tais problemas foram descritos como imutáveis pelos funcionários da instituição (GARBIN e TAVARES, 2000). Este estudo deu-se em razão de uma demanda de técnicos de saúde de uma Seção Judiciária da Justiça Federal ao CEREST/SP.

Embora os estudos acima citados se refiram a órgãos diferentes pertencentes ao Poder Judiciário e tenham tido objetivos e abordagens diversas (ARAGÃO, 1997, Justiça do Trabalho do Espírito Santo; GARBIN e TAVARES, 2000 e CORDEIRO, GARBIN e cols, 2000, Justiça Federal - Seção Judiciária), apresentam descrições comuns quanto aos problemas referentes à organização do trabalho e às políticas organizacionais.

Tais descrições coincidem com dados colhidos em sondagem preliminar baseada em entrevistas com técnicos da Divisão Médica, da Secretaria de Recursos Humanos, da Assessoria de Comunicação Social, do Escritório de Qualidade e da Escola de Magistrados da Justiça Federal de São Paulo (PARAGUAY e TAVARES, 2000). Esta sondagem ocorreu como forma de contato preliminar na instituição onde se daria o estudo posteriormente, com o objetivo de verificar, junto a estes técnicos, quais eram as questões relevantes de saúde do trabalho, no contexto do Tribunal. Os resultados da sondagem apontaram que os técnicos percebiam uma relação entre as questões de Saúde Mental e Trabalho e a forma como se estabelecem as relações entre funcionários e 
chefias, destacando-se o autoritarismo, a cobrança, conflitos, o poder excessivamente centralizado em magistrados, chefes e diretores.

Posteriormente a esta sondagem, foi desenvolvida uma etapa exploratória na instituição onde se deu o estudo que é motivo desta dissertação, com os objetivos de conhecer o trabalho e sua organização dentro da instituição, expressões lingüísticas próprias, e, principalmente, identificar se o sofrimento no trabalho seria um objeto de representação do grupo a ser estudado, tal como recomenda SÁ (1998). Também se teve por finalidade identificar possíveis categorias empíricas da representação social do sofrimento no trabalho. A etapa exploratória cumpriu um segundo papel de aproximação da questão de estudo com o campo de estudo. A primeira foi a sondagem preliminar com os técnicos de várias áreas da Instituição, como já dito. Na etapa exploratória a aproximação se deu com o grupo de estudo diretamente. SÁ (1998) nos fala do estudo exploratório nos projetos de pesquisa em Representações Sociais como um momento em que as perguntas que o pesquisador se fez inicialmente possam ser feitas também aos sujeitos da pesquisa (SÄ, 1998). Algumas expressões utilizadas pelos entrevistados foram consideradas como indicativas da idéia de sofrimento no trabalho para o grupo estudado:

fiquei tão fragilizada .... tem muito a ver com esse ambiente que a gente trabalha;

... aqui é barra, em termos emocionais, é muito pesado.

Você tem que ter uma estrutura emocional muito forte pra agüentar tudo; 
... lá (um dos setores da instituição no qual a pessoa já trabalhou) gerava o medo, a repressão...;

... você vai se desiludindo... só que se você continuar nessa ... de desilusão, você vai se matar;

Então, é como se fosse uma mente cauterizada;

... você vai perder a tua estrutura de vida;

Ou você se desliga ou você vai viver eternamente estressado;

... então vai afetando psicologicamente a pessoa, ela vai ... se sentindo impotente...;

... as vezes eu perco o sono quando eu pego um processo difícil... eu fico nervosa, eu não durmo a noite, começa a me dar dor de estômago...;

... quando eu vim pra cá, eu fiquei quase louca ... quase que aliás eu me exonero....

Então com essa pressão que eu sinto, eu fico doente ...

A etapa exploratória também permitiu levantar as seguintes categorias provisórias da representação social do sofrimento no trabalho: injustiça, volume excessivo de trabalho e pressão no trabalho, tal como sintetizado no mapa de associações, no anexo 3.

No Tribunal Regional Federal da $3^{\text {a }}$ Região (TRF-3 ${ }^{a}$ Região), uma pesquisa sobre a associação entre as condições de trabalho e o envelhecimento dos funcionários, confirmou a predominância de sobrecarga cognitiva, inadequação de mobiliários e equipamentos, além de exposição contínua a alérgenos (devido à grande quantidade de 
papéis armazenados em estantes sem isolamento), dados obtidos a partir da avaliação da pesquisadora (BELLUSCI, 1998). Quanto à saúde dos funcionários, os dados evidenciaram significativos índices de distúrbios músculo-esqueléticos e psicológicos entre servidores públicos judiciários. Os distúrbios músculo-esqueléticos apresentaram uma prevalência de 24,1\% em diagnóstico médico, tendo sido referidas por $40 \%$ dos funcionários da instituição; já os distúrbios do âmbito psicológico (depressão severa, depressão leve, tensão, ansiedade, insônia) foram diagnosticados em 8,7\% dos servidores, mas também foram referidas por uma porcentagem maior, 28,6\%. Os transtornos mentais também foram apontados pelos profissionais da área da saúde e social do Tribunal Regional Federal da $3^{\text {a }}$ Região de São Paulo, em levantamento preliminar (PARAGUAY e TAVARES, 2000) como sendo uma das principais causas de grande parte dos afastamentos do trabalho por motivos de saúde. No relatório anual de atividades realizado pelo TRF-3 ${ }^{a}$ Região em 1999, consta que dos atendimentos feitos pelo serviço social da $3^{\mathrm{a}}$ Região, 51\% estejam relacionados a saúde mental.

\subsection{Uma breve história do Poder Judiciário Brasileiro}

O Poder Judiciário teve formas diversas ao longo da história brasileira. Tais modificações em suas estruturas não se deram de forma linear ou progressiva, mas se constituíram, muitas vezes, em movimentos de avanços em determinadas direções e recuos, como por exemplo, na criação e posterior extinção de órgãos, que depois foram 
novamente integrados à estrutura do Poder Judiciário. Também sua autonomia e independência frente aos outros poderes modificaram-se ao longo do tempo, mas tal questão já se exclui de nossos objetivos. Interessa dizer que sua estrutura foi se tornando cada vez mais complexa e a demanda por seus serviços, crescente.

Apresenta-se a seguir alguns dados da evolução histórica de sua estrutura, tendo como base, o texto - Uma introdução ao estudo da Justiça -, de SADEK (1995).

No período colonial, a justiça no Brasil era representada por administradores da justiça nomeados pelos donatários. Esses últimos, no entanto, eram autoridades máximas do sistema judiciário brasileiro da época. Portanto, os administradores da justiça estavam subordinados aos donatários. As causas de maior relevância econômica eram decididas pelos Tribunais da Corte de Lisboa.

Em 1824, após a chegada da Família Real Portuguesa, a Carta Constitucional instaura os Poderes Judiciário, Executivo, Legislativo e Moderador. A independência do Poder Judiciário é declarada, mas ele continua sob o poder de intervenção e controle do Imperador.

A partir da Constituição de 1891, passam a ser o Poder Judiciário, o Executivo e o Legislativo os três poderes autônomos e independentes da República Federativa do Brasil. Também nesta Constituição assumiu-se uma divisão do sistema judiciário brasileiro entre Justiça Federal e Justiça dos Estados. A Justiça Federal já havia sido criada há um ano, por um decreto. O órgão de autoridade máxima no Poder Judiciário passou a ser o Supremo Tribunal Federal.

A Constituição de 1934 introduziu várias modificações na estrutura do Poder Judiciário. Regulamentou a Justiça Militar e a Justiça Eleitoral; promoveu modificações 
no funcionamento do Supremo Tribunal Federal; instituiu a Justiça do Trabalho enquanto órgão administrativo, não integrante do Poder Judiciário. Promoveu ainda várias modificações na Justiça dos Estados, atribuindo-lhe maior autonomia e melhores condições.

Por uma decisão do governo Getúlio Vargas, em 1937 a Justiça Federal e a Justiça Eleitoral foram extintas e a Justiça Estadual de $1^{\text {a }}$ instância passou a julgar todos os casos que envolvessem a União. O Supremo Tribunal Federal; os juízes e Tribunais dos Estados, do Distrito Federal e dos Territórios; os juízes e Tribunais militares passaram a ser os órgãos formadores do Poder Judiciário. A Carta Constitucional de 1937 atribui maiores poderes ao Executivo, e lhe concede a faculdade de legislar por decretos-leis, acabando por enfraquecer os Poderes Judiciário e Legislativo.

A Constituição de 1946, re-introduziu a Justiça Eleitoral; re-integrou a Justiça do Trabalho ao Poder Judiciário; criou o Tribunal Federal de Recursos, órgão de $2^{\mathrm{a}}$ instância, para causas envolvendo a União. A justiça de $1^{\text {a }}$ instância continuou a ser representada pelos juízes estaduais, remetendo-se estes aos Tribunais de Justiça e ao Tribunal Federal de Recursos, ao mesmo tempo.

Em 1965, a Justiça Federal voltou a existir e houve também outras mudanças que estimularam um aceleramento do trabalho da justiça e ainda uma grande redução da autonomia e independência da magistratura. O Legislativo e o Judiciário voltaram a ter suas autonomias bastante reduzidas, ficando mais subordinados ao Executivo, com os Atos Institucionais 2, 5 e 6 e pela Emenda Constitucional no 1, de 17/10/1969.

Com a Constituição de 1988, aumentou a autonomia administrativa e financeira do Poder Judiciário, que passou a elaborar orçamento próprio junto ao Executivo, a ser 
submetido ao Congresso Nacional. Ocorreu ainda ampla reorganização e redefinição das atribuições dos órgãos do Poder Judiciário, incluindo a extinção do Tribunal Federal de Recursos, a criação do Superior Tribunal de Justiça e dos Tribunais Regionais Federais, cujo objetivo foi descentralizar a justiça de $2^{\mathrm{a}}$ instância. Além disso, também se atribuiu aos Estados a organização de sua Justiça.

A seguir apresenta-se atual organograma do Poder Judiciário brasileiro. 
Figura 1 - Organização do Poder Judiciário Brasileiro

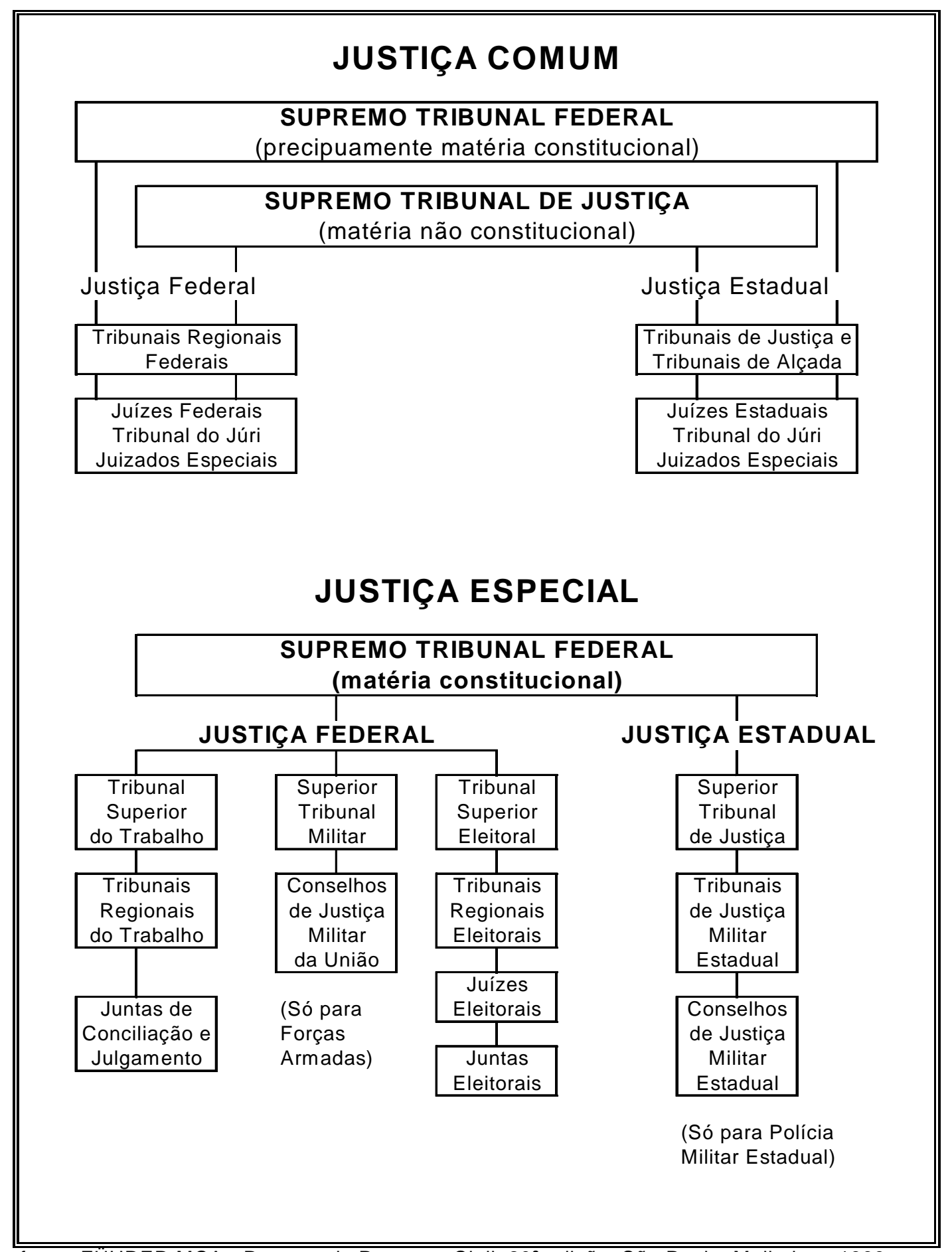

fonte: FÜHRER MCA - Resumo de Processo Civil. 20a edição. São Paulo: Malheiros, 1999. 
O Poder Judiciário ficou assim composto, segundo artigo 92 da Constituição Federal de 1988:

I. Supremo Tribunal Federal

II. Superior Tribunal de Justiça

III. Tribunais Regionais Federais ( $2^{\mathrm{a}}$ instância) e juízes federais (1 $1^{\mathrm{a}}$ instância)

IV. Tribunais do Trabalho ( $2^{\mathrm{a}}$ instância) e juízes do trabalho ( $1^{\mathrm{a}}$ instância)

V. Tribunais Eleitorais (2 $2^{\mathrm{a}}$ instância) e juízes eleitorais ( $1^{\mathrm{a}}$ instância)

VI. Tribunais Militares (2a instância) e juízes militares (1 $1^{\mathrm{a}}$ instância)

VII. Tribunais dos Estados, do Distrito Federal e dos Territórios (2ª instância) e juízes Estados, do Distrito Federal e dos Territórios (1ª instância)

Assim, mostra-nos FÜHRER (1999) a justiça pode ser Especial, quando se atém a matérias específicas, como a eleitoral, a militar e a do trabalho ou Comum, para os demais tipos de matérias. Pode ser do nível de $1^{\mathrm{a}}$ instância ou $1^{\circ}$ grau, a princípio a porta de entrada para toda demanda pelos serviços da Justiça, ou do nível de $2^{\mathrm{a}}$ instância ou $2^{\circ}$ grau, comumente quando ocorre recurso questionando decisão no nível da $1^{\mathrm{a}}$ instância. A $2^{\mathrm{a}}$ instância julga também alguns processos que entram diretamente nesta instância do Poder Judiciário.

A Justiça Comum pode ser Federal ou Estadual. Ao âmbito federal competem causas que envolvam a União, entidades autárquicas ou empresas públicas federais e ainda que digam respeito a assuntos relacionados a tratados e contratos da União com organismo internacional ou Estados estrangeiros (artigo 109 da Constituição Federal). 
Com o âmbito estadual ficam as demais causas não incluídas na competência da Justiça Federal Comum e das Justiças Especiais Federais.

Aos órgãos superiores: o Supremo Tribunal Federal e o Superior Tribunal de Justiça, competem, respectivamente, de forma sucinta, causas envolvendo matérias constitucionais e não-constitucionais, nos casos em que foi possível recurso após decisão da $2^{\mathrm{a}}$ instância.

\subsection{O Tribunal Regional Federal da $3^{a}$ Região}

Este estudo deu-se no Tribunal Regional Federal da $3^{\mathrm{a}}$ região (TRF-3 ${ }^{\mathrm{a}}$ região), criado na Constituição Federal de 1988, juntamente com outros quatro Tribunais Regionais Federais, como já dito acima, em substituição ao Tribunal Federal de Recursos. Com tal criação, se regionalizou a $2^{\mathrm{a}}$ instância da Justiça Federal.

O TRF-3 ${ }^{a}$ região foi inaugurado em 30 de março de 1989, ficando instalado, temporariamente, na sede do STJ (Superior Tribunal de Justiça), no $11^{\circ}$ andar do Fórum Pedro Lessa, à Avenida Paulista n 1682, até 05 de setembro de 1989. Depois disso, passou a ocupar o edifício “Saldanha Marinho”, sito à rua Líbero Badaró n 39. Devido a insuficiência das instalações neste prédio para as necessidades funcionais dos setores do TRF-3 ${ }^{\mathrm{a}}$ região, houve mudança de endereço em 22 de fevereiro de 1999, para prédio permutado com a Caixa Econômica Federal, localizado na Avenida Paulista nº 1842. 
São de competência do TRF-3 ${ }^{a}$ região todos os recursos de decisões proferidas pelos juízes de $1^{\mathrm{a}}$ instâncias das Seções Judiciárias de são Paulo e Mato Grosso do Sul ( $3^{\mathrm{a}}$ região) e ainda aqueles processos originários, ou seja, que dão entrada diretamente na $2^{\mathrm{a}}$ instância, sem passar pelos juízes de $1^{\mathrm{a}}$ instância. Neste último caso, seriam, por exemplo, aquelas ações relacionadas a juízes federais.

O TRF-3 ${ }^{\text {a }}$ região contava, no primeiro semestre de 2000, com 24 desembargadores ${ }^{4}, 2$ juízes convocados da $1^{\mathrm{a}}$ instância e 1 vaga a ser preenchida.

Os órgãos julgadores dos Tribunais Regionais Federais, diferentemente da Justiça Federal de $1^{\mathrm{a}}$ instância, são:

$-1^{\mathrm{a}}, 2^{\mathrm{a}}, 3^{\mathrm{a}}, 4^{\mathrm{a}}, 5^{\mathrm{a}}$ e $6^{\mathrm{a}}$ Turmas (compostas por 4 desembargadores cada uma);

- $1^{\mathrm{a}}$ e $2^{\mathrm{a}}$ Seções Especializadas (compostas, respectivamente por $1^{\mathrm{a}}, 2^{\mathrm{a}}, 5^{\mathrm{a}}$ turmas e $3^{\mathrm{a}}, 4^{\mathrm{a}}$, $6^{\mathrm{a}}$ turmas, ou seja, por 12 desembargadores cada uma);

- e Órgão Especial (composto por 18 desembargadores).

A seguir apresenta-se o organograma do Tribunal, com os setores (onde se deu o estudo) circunscritos por linha traço-ponto.

\footnotetext{
${ }^{4}$ Desembargador é a denominação funcional de um magistrado que se encontra na $2^{\mathrm{a}}$ instância do Poder Judiciário. Na $1^{\mathrm{a}}$ instância, ele é denominado juiz. Assim, Juiz e Desembargador são dois estágios da carreira da Magistratura, correspondentes, respectivamente, ao exercício da Magistratura na $1^{\mathrm{a}}$ instância e na $2^{\mathrm{a}}$ instância.
} 


\subsection{Alguns aspectos do regime jurídico dos servidores públicos civis}

O regime jurídico dos servidores públicos civis federais está instituído pela Lei no 8112, de 11 de dezembro de 1990. Desta Lei, destaca-se a seguir alguns aspectos, concernentes à inserção do funcionário e à composição de sua remuneração. A integração de um funcionário ao quadro de pessoal se dá mediante concurso público para cargos de caráter efetivo e ainda mediante nomeação em comissão para cargos de confiança, sem caráter efetivo. Os servidores que já façam parte do quadro efetivo também podem ocupar cargo de confiança por nomeação em comissão, sem prejuízo do cargo efetivo.

A nomeação em caráter efetivo é aquela decorrente exclusivamente de concurso público e se dá para os cargos de analista e técnico judiciários. A nomeação em comissão, vinculada à confiança e de livre exoneração, dá-se para funções de direção, chefia, assessoramento ou assistência, às quais é deferida uma gratificação.

Adicionalmente ao exercício dos cargos efetivos, o servidor pode ser nomeado para o exercício de função gratificada, ficando seu salário composto pelo vencimento referente ao cargo efetivo e à gratificação. Para as funções de direção, chefia e assessoramento, podem ser nomeadas pessoas que não compõem o quadro funcional de cargos efetivos. Já para as funções de assistência, adota-se a norma de apenas nomear pessoas que já façam parte do quadro funcional de cargos efetivos.

A Lei $\mathrm{n}^{0} 8.112$ determinava a incorporação em caráter permanente da gratificação ao salário do funcionário que tivesse exercido a função gratificada por 
determinado período, ainda que este viesse a não mais exercer tal função. Assim, estivesse o funcionário exercendo uma função que desse direito à gratificação, a cada ano de exercício, um quinto (1/5) do valor da gratificação adquiria caráter permanente na remuneração deste. Ao fim de cinco anos, ele passava a receber a gratificação em caráter permanente, mesmo que viesse a ser destituído da função. Tal determinação foi revogada posteriormente, não ocorrendo mis a incorporação permanente da gratificação ao salário do servidor, assim, este recebe apenas enquanto estiver ocupando o cargo em comissão ou a função gratificada.

\subsection{A assistência à saúde dos servidores do Poder Judiciário}

Os órgãos do Poder Judiciário contam com uma equipe de saúde, composta por assistentes sociais, dentistas, enfermeiros, médicos de mais de uma especialidade, psicólogos e técnicos de enfermagem. No entanto, não possuem profissionais especializados do campo de Saúde e Segurança do Trabalho. A necessidade de Serviço Especializado em Saúde e Segurança do Trabalho foi apontada por BELLUSCI (1998), na conclusão de seu estudo no Tribunal Regional Federal da $3^{a}$ Região, ainda que muitos dos aspectos identificados estejam, a princípio fora do alcance da intervenção de técnicos de uma equipe de saúde.

Como já relatado, houve uma demanda institucional de técnicos que reconhecem a relação entre aspectos do contexto de trabalho e a saúde dos servidores, evidenciando a 
necessidade de uma abordagem mais ampla de saúde, que leve em conta o contexto em que se situa a pessoa e o fato de que para promover a saúde é necessário intervir no trabalho, no ambiente de trabalho e na forma como ele ocorre no dia-a-dia. 


\section{OBJETIVOS}

- Identificar e analisar a representação social do sofrimento no trabalho, para um grupo de funcionários públicos do setor judiciário;

- Contribuir para a elucidação da relação saúde-trabalho no contexto citado, o setor do funcionalismo público judiciário, valorizando o conhecimento prático do trabalho como fonte de informações e significados. 


\section{METODOLOGIA}

\subsection{Delineamento do Projeto de Pesquisa ${ }^{5}$}

A explicitação da pesquisa, seus pressupostos, objetivos e finalidade dos resultados da pesquisa à população envolvida no estudo, bem como a negociação do trabalho de campo é de fundamental importância tanto para o desenvolvimento da mesma (PARAGUAY, 2000), como para o cumprimento ético da pesquisa em ciências humanas.

A medida em que a pesquisadora explicita seu projeto de pesquisa à população de estudo e à instituição e negocia as condições de desenvolvimento da mesma, realiza também uma aproximação das questões relevantes do contexto onde se dará o estudo, o que é essencial ao planejamento da pesquisa (PARAGUAY, 2000).

Dentro deste processo de diálogo com o campo a ser estudado, houve, como uma das fases iniciais, uma sondagem preliminar com os técnicos da área de Saúde, Recursos Humanos e Comunicação Social, a qual serviu de subsídio para o delineamento do projeto de pesquisa, como já explicitado anteriormente.

Após o delineamento inicial, o projeto de pesquisa em questão foi apresentado na instituição para os técnicos da área de Saúde, de Recursos Humanos e de Organização e

${ }^{\mathbf{5}}$ Esta pesquisa inseriu-se em um projeto maior denominado "Concepção, Gestão e Inovação Organizacional”, coordenado pela orientadora Profa. Dra. Ana Isabel B. B. Paraguay, da Faculdade de Saúde Pública da Universidade de São Paulo. 
Métodos. Em seguimento, a pesquisadora contatou pessoalmente todos os setores possivelmente envolvidos na coleta de dados, sendo apresentada pela assistente social da instituição, para reiterar as informações sobre o convênio de pesquisa e as ações a serem desenvolvidas nos meses seguintes, em relação à coleta de dados. Foram visitados pela pesquisadora 40 setores, para apresentação local das informações sobre a pesquisa. Nesta ocasião, foi distribuído um pequeno resumo do projeto e dados para contato com o grupo de pesquisa.

A etapa exploratória, que será descrita no próximo item, veio em seguida. Baseando-se nos resultados desta etapa exploratória, o projeto foi concluído e houve assim a apresentação com convite a todos os servidores.

As apresentações da pesquisa nos setores envolvidos no estudo foram o principal meio de prover os servidores de informações sobre a pesquisa, já que quase a totalidade deles não pôde estar presente à apresentação formal inicial.

Buscou-se que o delineamento do projeto de pesquisa fosse um processo de contínua interação com o campo ser estudado.

\subsubsection{A etapa exploratória}

Para a realização da etapa exploratória, foi escolhido um dos gabinetes, levando em conta o grau de receptividade dos funcionários e dirigentes em relação à pesquisa. A receptividade dos servidores do local foi considerada um elemento facilitador ao 
desenvolvimento desta etapa do estudo, que se caracteriza por ser exploratória, mais aberta a conteúdos não previstos e com a possibilidade de contar com entrevistas mais longas e menos estruturadas.

Foi realizada descrição das atividades de trabalho dos servidores e entrevistas semi-estruturadas.

A pesquisadora entrevistou inicialmente o chefe de gabinete, que descreveu, de forma breve, o processo de trabalho e a rotina daquele gabinete. Passou em seguida à observação não-sistematizada do trabalho naquele gabinete, a qual se deu mediante consentimento por escrito do dirigente do setor (termo de consentimento para observação - anexo 2).

A observação não-sistematizada no local de trabalho, bem como as entrevistas sobre a descrição das atividades, possibilitaram o reconhecimento da situação de trabalho e da divisão do trabalho, do ponto de vista do processo de trabalho, bem como da divisão de funções entre as pessoas.

Nas entrevistas sobre a descrição das atividades ocorridas com todos os servidores e em conversas informais, a pesquisadora convidou alguns dos servidores para a entrevista explicitando os seguintes critérios: os servidores mais novos e os mais antigos; servidores em todos os cargos e aqueles que desempenhassem tarefas únicas no gabinete.

Foram entrevistados nesta fase 5 servidores, com as seguintes características: 2 homens e 3 mulheres; 2 técnicos judiciários e 3 analistas judiciários; 2 ocupando cargos comissionados de assessor(a) e de chefe de gabinete e 2 exercendo função gratificada. 
Estas entrevistas, cujo roteiro se encontra no anexo 1, tiveram como tema a descrição do trabalho desenvolvido, aspectos da trajetória profissional, a percepção da Instituição enquanto ambiente de trabalho, aspectos positivos e negativos, bem como vantagens e desvantagens do trabalho e, finalmente a opinião e a vivência do entrevistado sobre as relações entre o trabalho e a saúde. O termo de consentimento para as entrevistas encontra-se no anexo 4.

O material coletado foi preparado e analisado seguindo-se os passos seguintes:

1. Transcrição literal de todas as entrevistas gravadas, incluindo digressões, repetições e outros tipos de expressões orais do entrevistado e do entrevistador. Tal prática teve por finalidade enriquecer o conteúdo a ser interpretado e também propiciar elementos para analisar a interação durante a entrevista. Foram corrigidos erros gramaticais e ortográficos, bem como adaptadas determinadas expressões da linguagem oral para a escrita. Por exemplo: Eu tava acostumada a mexe em processo (oral). Eu estava acostumada a mexer em processo (escrita).

2. Na primeira leitura, definiu-se um primeiro critério de organização do conteúdo das entrevistas, classificando-o em:

2.1. Descrição de atividades, descrição do processo de trabalho, descrição de regras e normas institucionais e outras questões referentes ao Poder Judiciário;

2.2. Qualificativos de algum aspecto do trabalho, do ponto de vista do bemestar e da saúde da pessoa entrevistada.

Numa segunda leitura do conteúdo classificado como qualificativos do trabalho quanto à saúde e ao bem-estar, buscaram-se trechos, expressões e explicações 
pronunciadas pelo entrevistado que nos indicassem relação com o sofrimento no trabalho.

3. A releitura das entrevistas para seleção de fragmentos dos discursos que se remetessem às expressões selecionadas acima ou que se seguissem à pergunta sobre os aspectos do trabalho percebidos como negativos, desgastantes do ponto de vista da saúde e a posterior categorização puderam trazer alguns indícios sobre os conteúdos da representação social acerca do sofrimento no trabalho para este grupo social. Foi construído um mapa de associações sobre o sofrimento no trabalho e suas categorias a partir dos dados coletados nesta etapa exploratória, que pode ser visualizado no anexo 3. No entanto, tal desenvolvimento só pode ser adequadamente fundamentado em etapa posterior, relatada a seguir.

Tendo se confirmado a significância do sofrimento no trabalho enquanto objeto de representação, passou-se para a reformulação do método, e depois para a coleta e análise dos dados do estudo propriamente dito.

Os resultados da etapa exploratória já foram abordados na Introdução, visto terem sido material de referência para o delineamento do estudo propriamente dito. Os procedimentos metodológicos para coleta e análise do material foram planejados a partir de resultados da etapa exploratória. 


\subsection{Composição do grupo de estudo}

Na delimitação da abrangência da pesquisa no contexto da instituição, optou-se por restringir o estudo àqueles setores envolvidos diretamente com as finalidades da instituição, os setores judiciários. Ficaram excluídas as áreas que desempenham atividades-meio, ou seja, os setores administrativos da instituição. Assim, os setores incluídos no estudo foram os gabinetes e as subsecretarias, cujas funções e processo de trabalho serão descritos adiante.

Foram convidados a participar do estudo 11 gabinetes e 4 subsecretarias. A escolha dos setores visou compor o grupo de forma diversificada segundo determinados aspectos, ou seja, buscou-se incluir tanto setores criados juntamente com a instituição, quanto aqueles criados posteriormente; também aqueles ocupados todo o tempo pelo mesmo magistrado e outros que tiveram mais de um magistrado no decorrer de sua existência e ainda aqueles com maior número de processos e aqueles com menor número de processos. O convite foi feito aos dirigentes por uma das assistentes sociais do serviço de assistência médico-social.

Dos setores convidados, aceitaram participar 9 gabinetes e 4 subsecretarias. Dos gabinetes que declinaram o convite, um deles justificou não ter servidores dentro de um dos critérios estabelecidos (ter mais de 6 anos de trabalho na instituição) e o outro justificou estar o gabinete com sobrecarga de trabalho no período da realização das entrevistas. 
Após o aceite, foi marcada uma visita inicial da pesquisadora a cada setor, com fins de: a) obter dados objetivos sobre fluxo de trabalho, composição do setor, tempo de existência do setor, divisão do trabalho com o chefe de gabinete - ver anexo 6 - dados de caracterização do setor coletados na visita inicial ; b) explicitar ao chefe de gabinete e aos servidores os critérios para escolha dos entrevistados; c) convidar aqueles servidores que atendessem aos critérios para a entrevista e coletar dados do convidado à entrevista, como tempo de serviço, cargo ocupado, escolaridade, outros setores em que trabalhou dentro da instituição e informações sobre as atividades desempenhadas. Tais visitas foram feitas no período de duas semanas.

Os critérios de inclusão no grupo de estudo objetivaram uma representatividade de subgrupos dentro do grupo estudado, abrangendo as múltiplas dimensões do fenômeno a ser estudado. Em conseqüência, a definição das pessoas a serem entrevistadas contemplou os grupos profissionais: - dirigentes (diretores das subsecretarias e chefes dos gabinetes) e -funcionários públicos sem cargo de direção ou chefia (analistas judiciários e técnicos judiciários). Além disso, as pessoas entrevistadas, com exceção dos dirigentes, estavam entre aquelas com maior tempo de trabalho na instituição (28\% dos funcionários tem de 10 a 12 anos de experiência) e ainda, preferencialmente, aquelas que já tinham trabalhado em mais de um setor da área judiciária dentro da instituição. Optou-se por excluir do grupo de estudo os desembargadores e seus assessores, pelo entendimento de que estes compartilham menos o contexto de trabalho dos setores da instituição, estando mais voltados a questões externas ou além do cotidiano de trabalho. 
Sabendo-se que os critérios de diferenciação se referem a ocupar ou não cargo de direção ou chefia e que há apenas 1 dirigente por setor, o número de entrevistados, segundo planejamento, se encontrava entre 30 e 50 pessoas. Ao todo, 50 servidores foram convidados e aceitaram ao convite para a entrevista. Tendo aceitado o convite, era marcado um horário de comum acordo.

Compareceram à entrevista 37 funcionários, dos 50 com os quais havia sido marcada entrevista.

\subsection{Coleta de dados}

A entrevista configurou-se como semi-estruturada, que se baseia em questões que definem a área a ser explorada, inicialmente, e a partir das quais o entrevistado e o entrevistador podem desviar-se para alcançar uma idéia ou resposta mais detalhada (BRITTEN, 2000). Visou a caracterização do contexto de trabalho, partindo-se do conhecimento e vivência das pessoas que nele trabalham. As questões do roteiro (roteiro de entrevista - anexo 5) nortearam a entrevista, sem contudo direcioná-la ou restringir os temas, privilegiando-se também aspectos levantados pelo entrevistado. Foram abordados os seguintes tópicos: a) caracterização profissional; b) descrição do trabalho; c) sofrimento no trabalho - como o define, explica e sente, exemplos de situações, formas de enfrentá-lo; d) expectativas profissionais. 
Quanto à situação de entrevista, destaca-se aqui como algo a buscar o que BOURDIEU (1999) denominou como escuta ativa e metódica, [que] associa a disponibilidade total em relação à pessoa interrogada, a submissão à singularidade de sua história particular, que pode conduzir, por uma espécie de mimetismo mais ou menos controlado, a adotar sua linguagem e a entrar em seus pontos de vistas, em seus sentimentos, em seus pensamentos, com a construção metódica, forte, do conhecimento das condições objetivas, comuns a toda uma categoria.

A duração do período de realização das entrevistas foi de dois meses. As entrevistas se realizaram na sala da psicologia ou do serviço social da equipe de saúde da instituição, cujas instalações ofereciam a condição necessária de sigilo e certa neutralidade. Todas as entrevistas ocorreram mediante consentimento por escrito (termo de consentimento para entrevista - anexo 4).

\subsection{A análise dos dados}

O método de análise baseou-se em análise de conteúdo, cujos procedimentos se formaram pela tomada de conhecimento de métodos e técnicas já utilizados em outros estudos (BARDIN, 1988; VALA, 1986; OLIVEIRA, 1991; SATO, 1991) e subseqüente reformulação atinente aos objetivos da presente pesquisa. 
A análise de conteúdo pode ser definida como um conjunto de técnicas de análise de comunicações voltadas à explicitação e sistematização do conteúdo das mensagens e da expressão deste conteúdo (BARDIN, 1988). Tais técnicas contribuem por afastar os perigos da compreensão espontânea, pelas quais, o pesquisador familiarizado ou não com seu objeto de estudo, pode por a prova interpretação inicial do material (BARDIN, 1988). A Análise de Conteúdo contribui também para o enriquecimento da leitura, descoberta de conteúdos e esclarecimentos de relações não explicáveis somente pela leitura. Ao falar sobre o processo de análise, VALA (1986) evidencia os resultados desta análise como fruto do processo de interação entre as condições de produção do discurso e as condições de produção da análise:

Trata-se da desmontagem de um discurso e da produção de um novo discurso através de um processo de localização-atribuição de traços de significação, resultado de uma relação dinâmica entre as condições de produção do discurso a analisar e as condições de produção da análise (VALA, 1986).

Neste estudo utilizou-se análise categorial, que funciona por desmembramento do texto em unidades, em categorias segundo reagrupamentos analógicos (BARDIN, 1988).

Procedeu-se a análise segundo os seguintes passos:

a) Identificação das palavras ou expressões que se referiam ao sofrimento no trabalho, tais como as exemplificadas na etapa exploratória; 
b) Seleção de fragmentos dos discursos aos quais as palavras ou expressões acima especificadas remetiam. Tais fragmentos podem denominar-se Unidades de Contexto, utilizando-se do termo de BARDIN (1988, p. 107) para se referir aos segmentos da mensagem que são úteis para se compreender a significação das Unidades de Registro, abaixo explicitadas. Ou ainda pode-se chamar de Núcleos Organizadores de Discurso, que significa os elementos que dão sustentação e coerência às falas [e que] representam o primeiro nível de segmentação e reorganização dos discursos OLIVEIRA (1998, p. 167). Por exemplo: ... Eu assumi postos de comando, hoje não estou mais, amanhã posso ser colocado pra empurrar carrinho... aí você pensa: Pô, mas voltar à estaca zero? É uma coisa que também causa uma certa angústia. Porque todo o tempo, todo o trabalho que você fez, parece que nada daquilo valeu... não sei. Mas se tem essa impressão. E pelo que eu sinto, não é só minha, é do conjunto de funcionários que têm mais tempo de serviço;

c) As Unidades de Registro seriam a unidade de significação (BARDIN, 1988, p. 104), ou seja, no estudo em questão, os elementos do trabalho relacionados ao sofrimento. As unidades de registro corresponderiam às frases modais ou expressões de sentido (OLIVEIRA, 1998), que seriam aquelas frases típicas que contém um grande número ou porcentagem de palavras que participam do universo de dados estudados (OLIVEIRA, 1998, p. 167). A relevância das unidades de registro ou frases modais serão definidas pelo critério de freqüência, de intensidade (indicadores semânticos) e ordem de aparição. No exemplo dado no item (c), a unidade de registro seria $a$ possibilidade de voltar à estaca zero, que significa ter ocupado ou ocupar cargo 
comissionado na instituição e vir a perdê-lo ou ter a eterna possibilidade de vir a perdêlo, a qualquer momento, voltando ao ponto do início da carreira na instituição;

d) O próximo passo foi a categorização, a qual implicou em classificar as unidades de registro por diferenciação, atentando para os princípios da homogeneidade, da exclusão mútua e pertinência com o quadro teórico. Tal categorização se deu por critério expressivo (BARDIN, 1988), ou seja, as unidades de registro agrupadas sob a mesma categoria devem expressar um significado em comum, construído em decorrência do quadro teórico. Para o exemplo utilizado, a categoria seria Estagnação Profissional ou Angústia da Estaca Zero, a qual resume a idéia de que o sofrimento estaria ligado à experiência de não ter a possibilidade de desenvolver carreira no Tribunal ou ainda de vir a galgar alguns degraus da hierarquia, mas sempre com a possibilidade de voltar ao ponto inicial da carreira, pela exoneração do cargo;

e) As categorias foram agrupadas em 3 agrupamentos de sentido, segundo critérios semânticos explicitados adiante, nos resultados. No exemplo dado acima, o agrupamento de sentido seria Elementos Constitutivos do Sofrimento no Trabalho;

f) Dos textos das entrevistas, também foram selecionados os trechos referentes às expectativas profissionais dos entrevistados com fim de relacioná-las aos resultados sobre a representação social do sofrimento no trabalho. Tal relação foi primeiramente evidenciada na etapa exploratória e posteriormente analisada no estudo propriamente dito. 


\subsection{A devolutiva de resultados para os entrevistados}

Com o intuito de garantir aos entrevistados a oportunidade de acesso aos resultados e ainda como forma de consolidação dos mesmos, foi realizada devolutiva dos resultados parciais aos entrevistados, individualmente, após, aproximadamente, dois meses da finalização das entrevistas. As entrevistas de devolução ocorreram no mesmo local, as salas da assistente social e da psicóloga da equipe de saúde e social.

Também foi realizada apresentação coletiva dos resultados finais primeiramente para a equipe de saúde e, posteriormente, no I Fórum de Saúde Psicossocial na Justiça Federal, evento aberto a todos os servidores, após um ano da finalização das entrevistas. 


\section{RESULTADOS E DISCUSSÃO}

\subsection{Caracterização da população de servidores}

No primeiro semestre de 2000, o quadro efetivo totalizava 1336 servidores, dos quais, 843 pertencem à área-fim (jurídica) do Tribunal e o restante, à área-meio (administrativa).

A seguir apresenta-se caracterização de tempo de trabalho na instituição, nível de escolaridade e gênero da população total de funcionários. Esta caracterização diz respeito ao primeiro semestre de 2000, época em que ocorreram os primeiros contatos com a Instituição.

A instituição, inaugurada em 30 de março de 1989, apresentava 12 anos de idade em 2001, época da coleta de dados. O ingresso de servidores deu-se segundo gráfico seguinte:

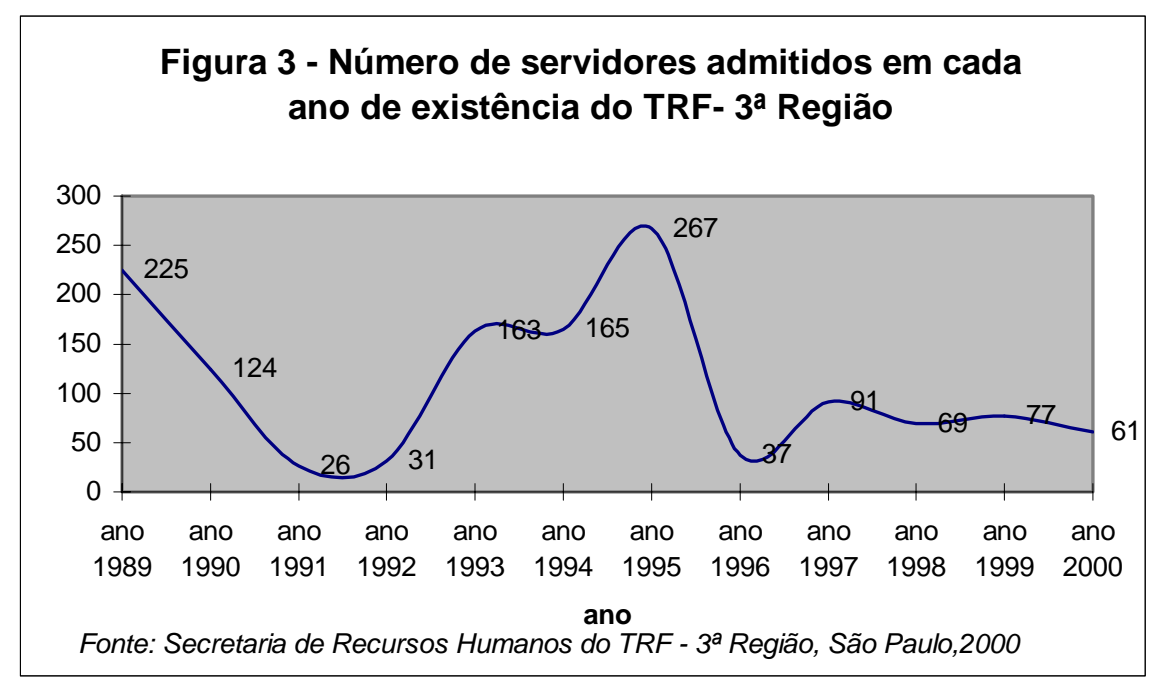


Do total de servidores, $17 \%$ deles encontram-se desde a inauguração. Parece ter havido um significativo crescimento do corpo de servidores entre os anos de 1993 e 1995.

Então, quanto ao tempo de serviço, tem-se o seguinte:

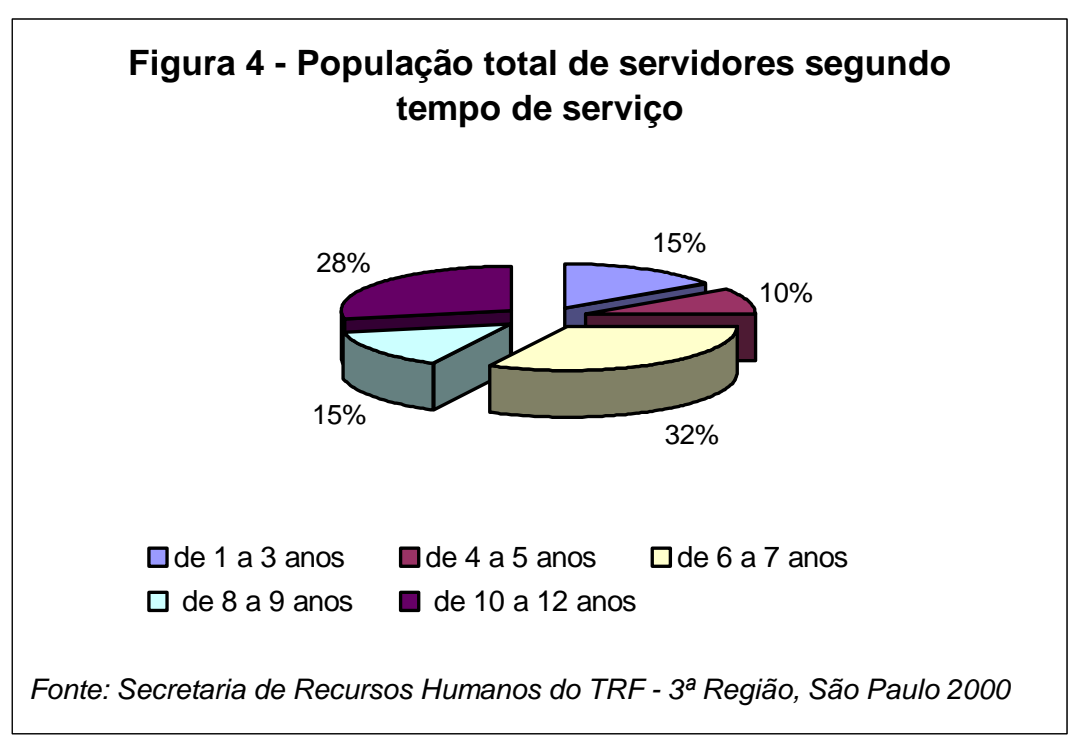

Como se vê, a fatia de tempo de serviço escolhida como critério para inclusão no grupo de estudo corresponde à cerca de $75 \%$ do total de servidores.

No gráfico a seguir, percebe-se que o nível de escolaridade na população de servidores do órgão estudado é alto, sendo que 55\% deles possuem curso superior. Isto pode se dever tanto à natureza do trabalho no Tribunal quanto à forma de seleção de mão-de-obra, o concurso público. No item que informa sobre o nível de escolaridade do grupo estudado, se verá que mesmo dentre aqueles que ocupam cargos de nível médio, que não exigem curso superior, o número de diplomados em Direito é significativo. 
Figura 5 - População Total de Servidores Segundo

\section{Escolaridade}

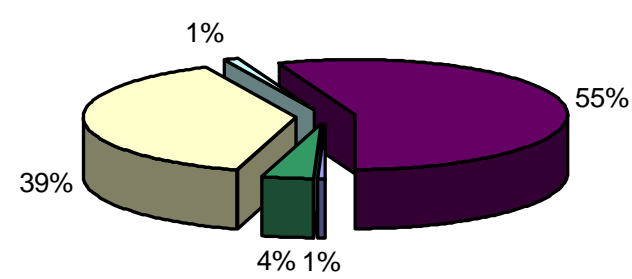

$\square$ Primário completo

$\square 1^{\circ}$ grau completo

$\square 2^{\circ}$ grau completo

$\square$ Pós-graduação

$\square 3^{\circ}$ grau completo

Fonte: Secretaria de Recursos Humanos do TRF - $3^{a}$ reqião, São Paulo 2000

Quanto ao gênero, nota-se uma leve predominância de mulheres no total de servidores:

Figura 6 - População total de servidores segundo gênero

$47 \%$
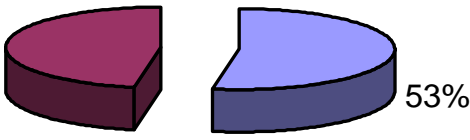

$\square$ Feminino $\square$ Masculino

Fonte: Secretaria de Recursos Humanos do TRF - $3^{a}$ região, São Paulo 2000 


\subsection{Caracterização do grupo de estudo}

Dos 50 servidores convidados, compareceram à entrevista 37 pessoas. Durante a primeira semana reservada às entrevistas houve greve dos servidores da Justiça Federal. Apesar de não ter havido adesão integral à greve, tal fato trouxe alguns empecilhos ao início das entrevistas. Algumas das faltas às entrevistas foram justificadas pelos servidores em razão da greve.

No grupo de estudo, a porcentagem de mulheres (68\%) é maior do que na população geral de servidores do órgão estudado (53\%):

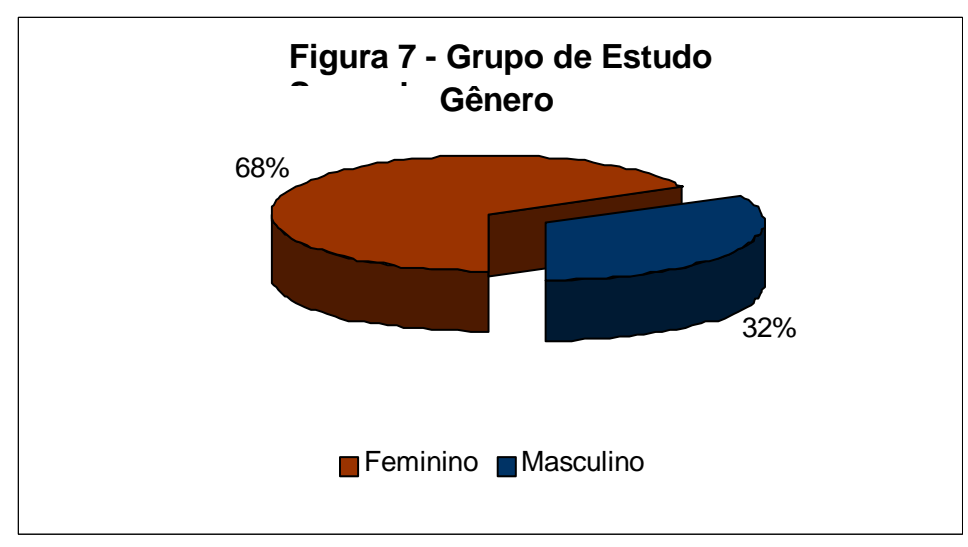

Pode-se aventar a hipótese de as mulheres terem sido mais receptivas à participação na pesquisa. Quanto a participação delas em cargos comissionados, tem-se que, entre os entrevistados, a porcentagem de mulheres em cargos comissionados é de $52 \%$, enquanto que a de homens é de $25 \%$, ou seja, das mulheres entrevistadas, $52 \%$ ocupam ou já ocuparam cargos comissionados (chefia, direção ou assessoria) e dos homens entrevistados, 25\% ocupam ou já ocuparam tais cargos. Este dado provavelmente não encontra correspondência no todo da participação feminina em 
cargos comissionados. Na Administração Pública Federal, os cargos comissionados são apenas minoritariamente ocupados por mulheres, sabendo-se que apenas $13,24 \%$ dos cargos mais altos hierarquicamente são ocupados por mulheres e, mesmo no cargo comissionado mais baixo, a participação feminina é de 45,53\% (ACCO e cols, 1998).

O grau de escolaridade predominante no grupo de entrevistados é o de nível superior. Dos entrevistados, 90\% possui nível superior, porcentagem maior do que na população geral de servidores. Dada a natureza do trabalho em gabinetes, estes acabam agregando os servidores bacharéis em Direito, que são maioria dentre os possuidores de curso superior. A escolha pelo curso de Direito deu-se, para boa parte deles, em função do trabalho. Os motivos alegados foram: uma melhor adaptação à natureza do trabalho e ainda as expectativas de crescimento, já que para ocupar cargos de direção, chefia ou assessoria é necessário ter curso de Direito.

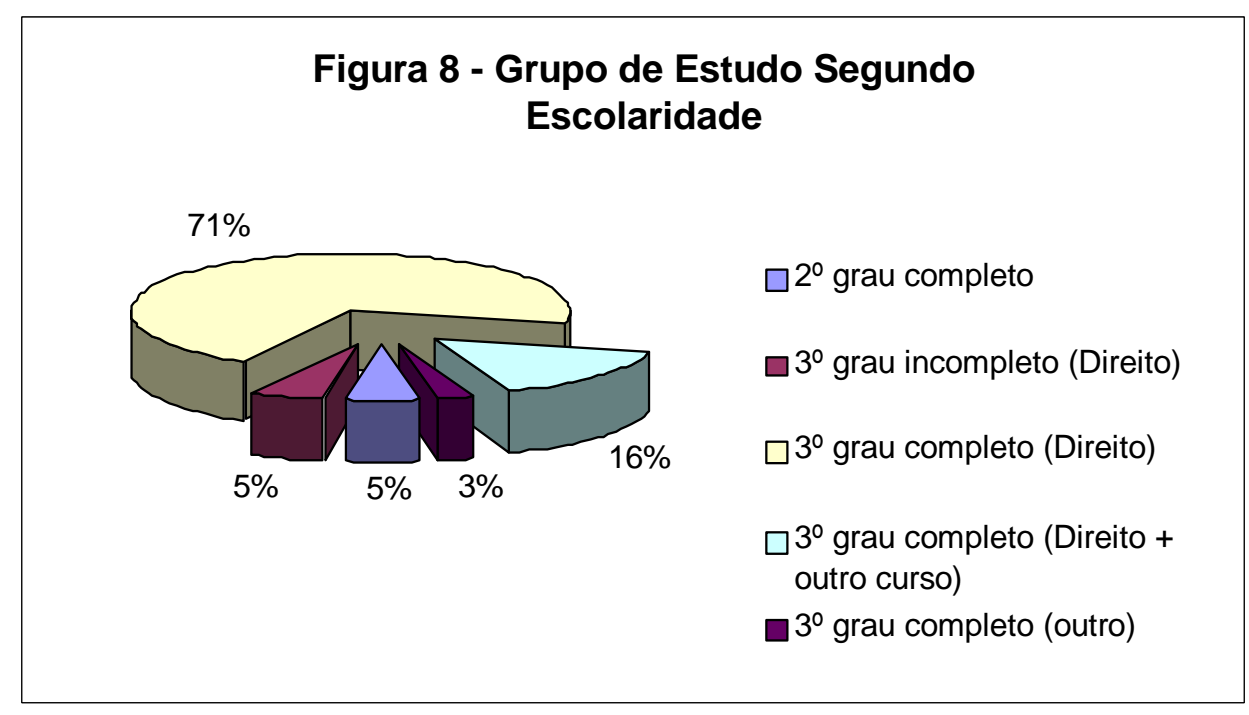

Apesar do cargo de técnico judiciário não exigir curso superior, 87\% de seus ocupantes o possuem. 
Figura 9 - Presença de curso superior em técnicos e analistas

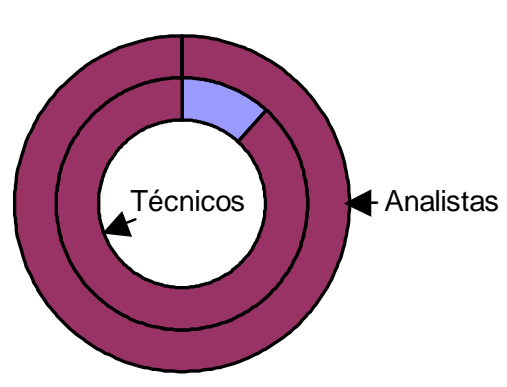

$\square$ sem curso superior $\square$ com curso superior

Dentre os entrevistados, 57\% ocupam cargo de nível superior de Direito. Em seguida se verá que a maioria dos entrevistados são de gabinetes. Nestes, há maior quantidade de analistas do que nas subsecretarias. Isto pode explicar o maior número de entrevistados analistas.

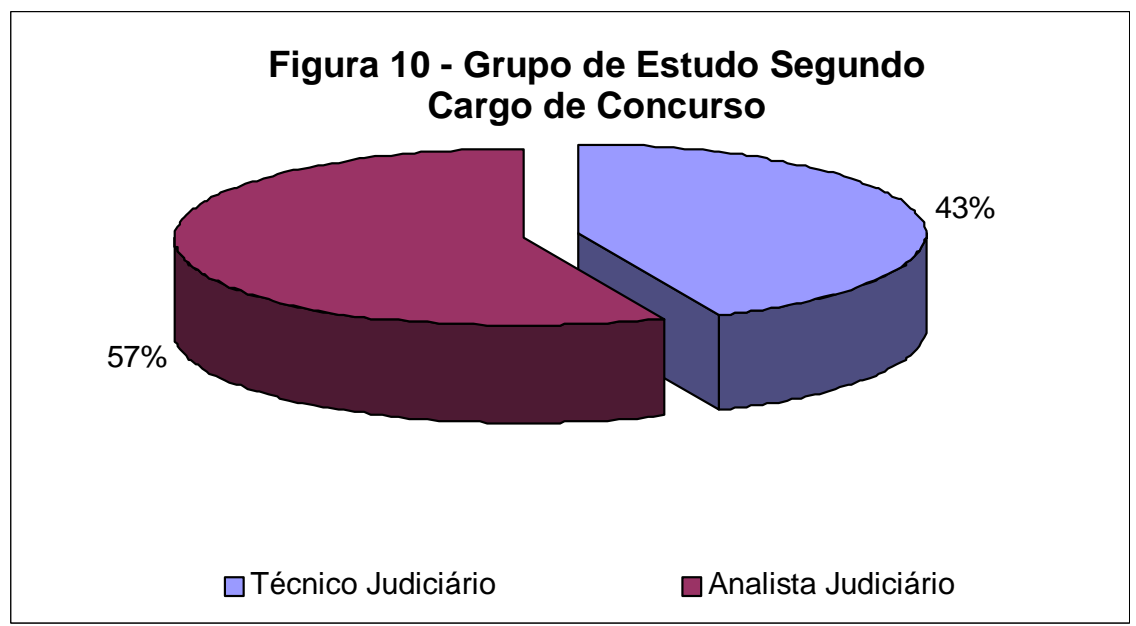


Há uma proporção próxima de cada grupo de servidores, divididos segundo tempo de trabalho (ver abaixo).

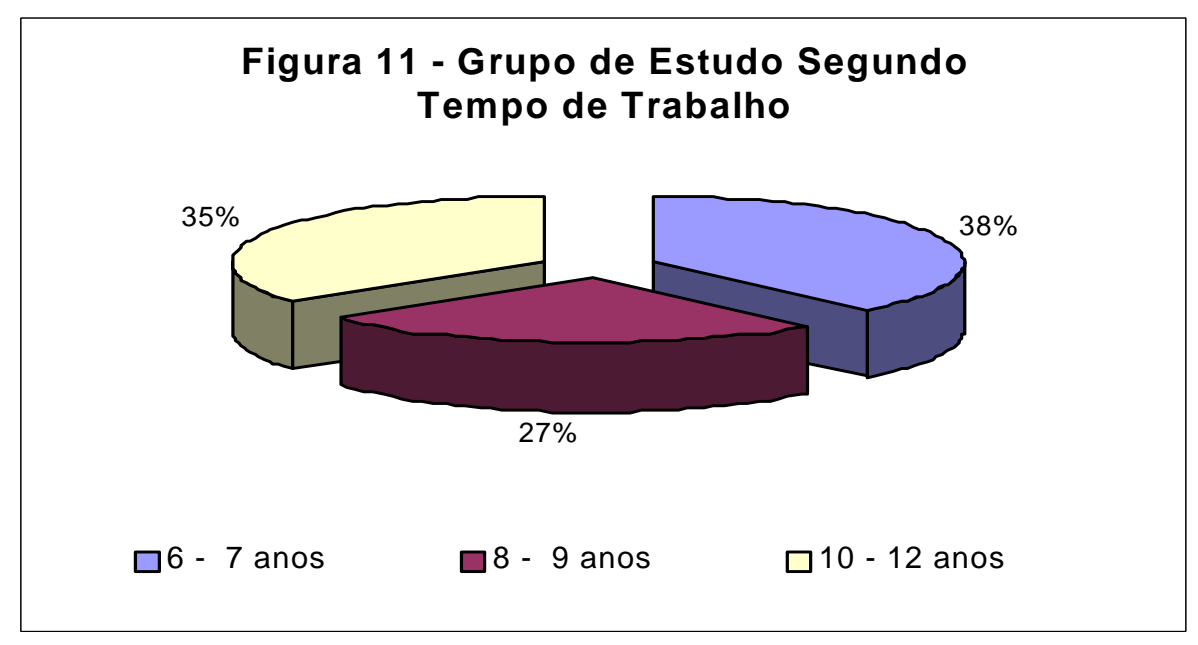

A maior parte dos servidores entrevistados são de gabinetes. Como será visto, o ritmo de trabalho nas subsecretarias é intenso e se encontra fora do controle dos servidores ou da direção, mantendo relação direta com a própria demanda pelos serviços do Judiciário. Este pode ter sido um dos motivos de haver menor número de entrevistados originários das subsecretarias. Ademais, houve maior dificuldade de encontrar servidores com mais de 6 anos de tempo de serviço nas subsecretarias. Parece haver uma tendência de as subsecretarias agregarem servidores com menor tempo de casa.

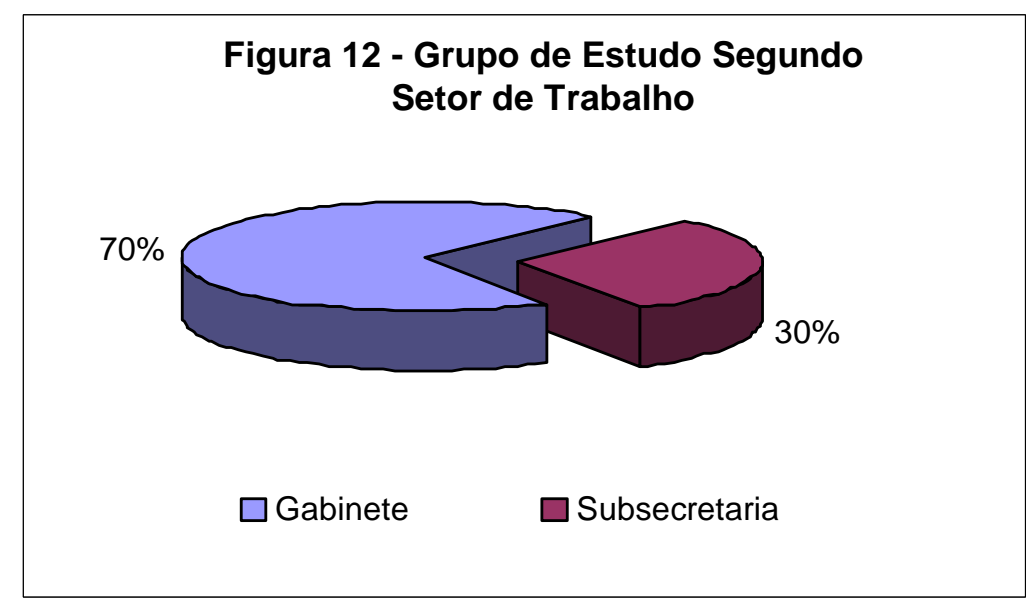


Dentre os entrevistados, 43\% já ocuparam cargos de chefia ou direção por nomeação, sendo que 32\% do total ocupam atualmente.

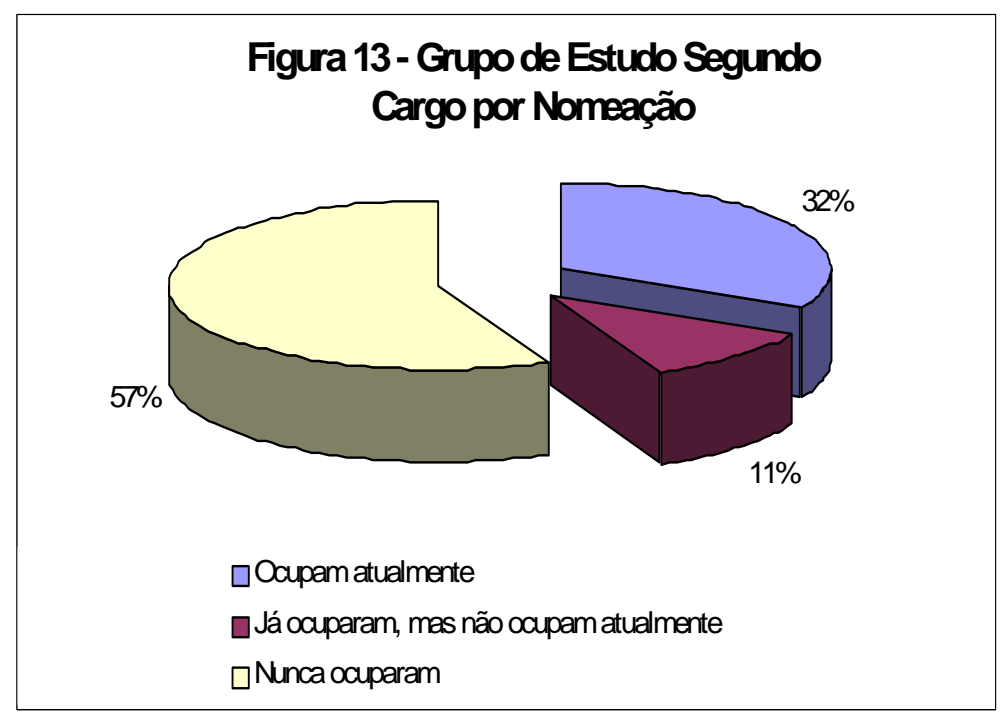

Houve uma significativa participação de servidores com função gratificada no estudo, já que 79\% dos entrevistados exercem função gratificada. Sabe-se que um dos critérios para a concessão de gratificações é a antiguidade do vínculo de trabalho. Como se buscou entrevistar os servidores mais antigos da instituição, isto pode ter levado a concentrar maior número de servidores com função gratificada no grupo de estudo.

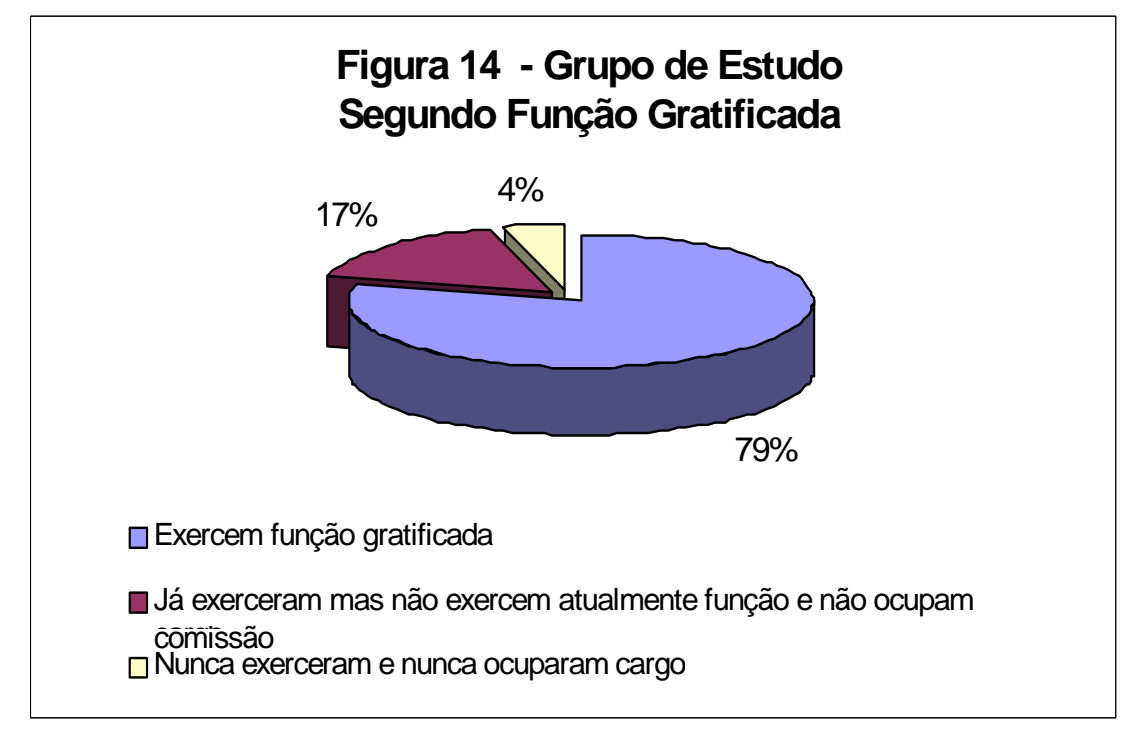


Quanto aos trabalhos já exercidos pelos entrevistados, anteriormente ao órgão estudado, têm-se que boa parte das ocupações anteriores (32\%) foram em cargos de nível médio no serviço público. É significativo ainda que 50\% das ocupações tenham sido no serviço público de modo geral. Apenas 26\% deles já haviam trabalhado como advogados ou bacharéis em Direito anteriormente.

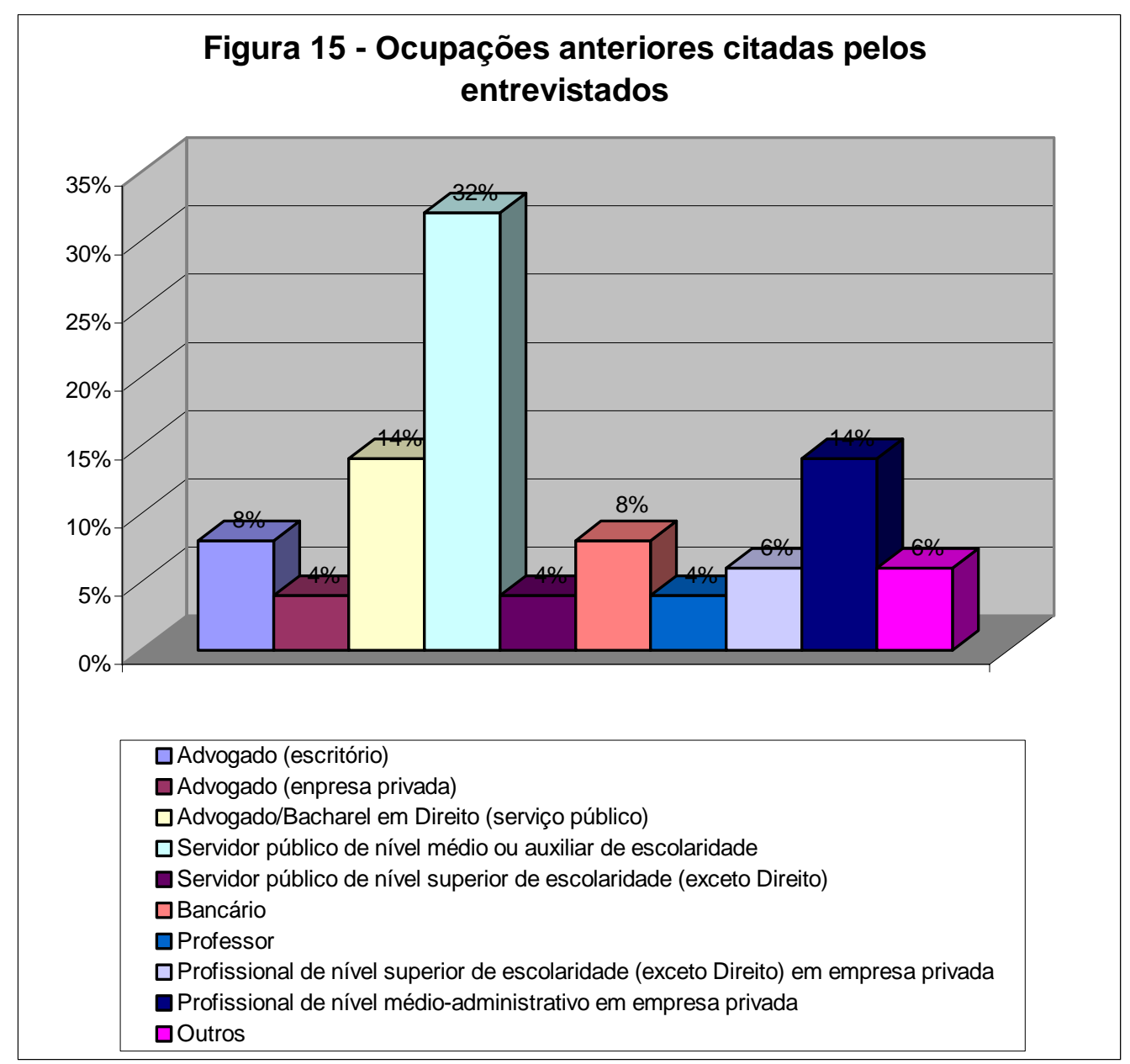




\subsection{Processo de trabalho nos setores: gabinetes e subsecretarias}

Os setores onde se deu o estudo foram:

- $\quad$ os gabinetes, onde se analisam os processos, pesquisa-se e preparam-se os mesmos para a decisão;

- e as subsecretarias, que secretariam as turmas de magistrados, ou seja, executam as providências necessárias para que os processos entrem, sejam encaminhados aos devidos setores, sejam julgados e se tornem públicos.

A seguir se faz caracterização dos setores nos quais se deu o estudo.

Estes dados foram obtidos na visita inicial a cada setor, com os dirigentes e os servidores (ver anexo 6 - dados de caracterização dos setores coletados na visita ao setor) e ainda na entrevista para a identificação da representação social do sofrimento (ver anexo 5 - roteiro de entrevista).

\subsubsection{Os gabinetes}

\section{Composição padrão do efetivo dos gabinetes}

1 desembargador(a) - [magistrado(a)];

1 assessor(a); 
1 chefe de gabinete;

17 funcionários(as), em média, sendo 2 agentes de segurança, e o restante técnicos(as) judiciários (nível médio de escolaridade) e analistas judiciários (nível superior de escolaridade). Dentre estes, em média sete exercem funções gratificadas, recebendo quantia adicional no salário por tal atribuição;

2 a 4 estagiários(as).

\section{Caracterização geral do trabalho no gabinete}

1) Os processos chegam diariamente no gabinete, com guias de remessa. Em geral, um ou mais dos funcionários ou estagiários recebem os processos, conferindo informação da guia de remessa com os processos, verificando se a matéria da qual trata o processo é competência de seu gabinete.

Um ou mais funcionários registram entrada no terminal de dados, separam os processos por tipo de assunto e guardam-nos em armário, o qual, em geral, é organizado por tipo de matéria e data da chegada.

2) Em alguns gabinetes, além da divisão por tipo de matéria e tipos de assunto dentro de cada matéria, os processos também são organizados, informalmente em 2 grupos, dentro de cada matéria, com a finalidade de separar os processos mais rápidos e simples de serem trabalhados daqueles complexos ou de demandas novas, sem entendimento já consensual. A divisão mostra-se da seguinte forma: a) Aqueles cujo conteúdo é semelhante a processos anteriores, tendo já uma resolução pré-definida e 
consolidada entre os desembargadores. Diz-se, nos gabinetes, que estes processos têm um modelo padrão de voto, o qual é utilizado para fazer os votos dos processos que surgem com a mesma demanda ou assunto. b) Aqueles com demandas únicas ou que ainda não se tem um entendimento consensual sobre a questão, necessitando de pesquisa e estudo.

3) Geralmente um ou mais funcionários são incumbidos de determinados casos, que não são propriamente decisões finais em processo, mas decisões intermediárias no julgamento, necessitam ser atendidos com certa urgência.

4) Dentre aqueles processos que já têm um voto padrão a ser utilizado, o funcionário faz o voto, em seguida passa o processo para o responsável pela revisão (geralmente um funcionário mais experiente, o chefe de gabinete ou o assessor), o qual o confere e este é incluído na pauta de julgamento. Isto significa que o processo passará pela sessão de julgamento dentro de um mês, em média. Conforme o gabinete, há variações nesse procedimento. Por exemplo, há gabinetes em que os processos a irem para pauta são definidos previamente, e depois disso, são trabalhados pelos funcionários. Além disso, o processo de revisão varia conforme o gabinete, o tipo de matéria envolvida, a experiência de trabalho do funcionário e a preferência do desembargador.

5) Alguns gabinetes possuem um ou dois funcionários incumbidos exclusivamente do atendimento ao balcão e da organização dos processos nas prateleiras. Isto se dá, geralmente, quando o gabinete tem um número excessivo de processos, necessitando constantemente alocar mais espaço para os processos e, conseqüentemente, consulta intensa de partes e advogados. 
6) A tarefa de fazer a pauta, que se constitui em um resumo dos processos a serem julgados semanalmente, pode ser feita, em alguns gabinetes por um funcionário, em outros pelo chefe, e em outros gabinetes pode ser que cada funcionário faça o resumo dos processos nos quais trabalhou.

No dia de julgamento, que ocorre semanalmente, o desembargador, o chefe e/ou o assessor e 1 ou 2 funcionários mantém-se distantes, pelo menos por um período do dia, do gabinete, enquanto estão na sessão de julgamentos. O restante dos funcionários permanece no gabinete em suas funções normais. No entanto, o dia de julgamento pode ser de apreensão, para a maioria dos servidores, em decorrência de possíveis erros cometidos nos processos e repercussões destes. Em decorrência da elevada demanda, há a prioridade de se levar o maior número possível de processos a julgamento semanalmente, dificultando a revisão de todos os processos que vão a julgamento, o que, eventualmente, pode resultar em erros.

\section{Dados de observação do ambiente de trabalho}

O gabinete é um local de trabalho silencioso e formal. O aspecto visual transparece organização, limpeza. Cada funcionário possui uma bancada de trabalho, com espaço para atividades de escrita manual e um computador. As bancadas são separadas por divisórias com altura que permite, a quem estiver sentado, uma visão do ambiente e dos rostos dos demais colegas que estiverem também sentados nas outras bancadas do ambiente. O chefe de gabinete e o assessor possuem, cada um, ambiente 
próprio, delimita por divisória de material transparente, na sala do gabinete. A sala do desembargador é ampla, com sofás, mesinha, extensas prateleiras com livros, mesa e cadeira. Para chegar até ela, passa-se pelo gabinete e em frente ao ambiente do assessor.

\subsubsection{As Subsecretarias}

\section{Composição padrão do efetivo das subsecretarias}

1 diretor(a) da subsecretaria;

3 subdiretores(as) de divisões da subsecretaria;

15 a 20 funcionários(as), sendo técnicos(as) judiciário (nível médio de escolaridade) e analistas judiciários (nível superior). Dentre estes, em média oito exercem funções gratificadas, recebendo quantia adicional no salário por tal atribuição; 2 a 4 estagiários(as).

\section{Caracterização geral do trabalho nas subsecretarias}

As subsecretarias estão divididas em 3 divisões, a saber: 1) coordenação e julgamento; 2) processamento; e 3) procedimentos diversos. Cada divisão tem um diretor, subordinado ao diretor da subsecretaria e todas ocupam a mesma sala. 
Apesar de haver uma padronização de tarefas formalmente atribuídas a cada divisão, na prática das subsecretarias, esta divisão não é seguida e não há uma divisão exata de tarefas entre as divisões em todas as subsecretarias, funcionando mais como uma divisão de responsabilidades por tarefas entre grupos de cada subsecretaria. Assim, numa subsecretaria, uma tarefa pode estar sob a responsabilidade de uma divisão e noutra subsecretaria, sob a de outra divisão, a depender do montante de responsabilidades a ser dividida. Aproximadamente, a divisão se dá da forma a seguir apresentada. A primeira divisão organiza os julgamentos, prepara as pautas, verifica se há impedimentos nos processos em pauta, secretaria as sessões de julgamentos, atualiza as informações sobre as decisões no sistema de informações. A divisão de processamento cumpre os despachos dos juízes, instrui os processos. A última divisão, a de procedimentos diversos, faz as publicações, expede documentos.

A subsecretaria recebe os processos e documentos vindos da distribuição, dos gabinetes e do protocolo; analisa determinados itens nos processos (questões pontuais, apenas); expede ofícios, documentos; atende às partes e aos advogados para informar sobre o andamento dos processos; arquiva processos e petições; atualiza o sistema com informações referentes aos processos e seus andamentos.

O atendimento ao balcão ocorre das 9 horas às 17 horas e em geral é feito por todos os servidores da subsecretaria.

\section{Dados de observação do ambiente de trabalho}

Na subsecretaria, diferentemente do gabinete, a delimitação dos espaços dos servidores não é clara. Em alguns casos, não se distingue qual é a mesa dos diretores. Há 
pilhas de processos nas mesas e corredores, dando impressão de que o espaço do ambiente é insuficiente para a quantidade de processos e matérias que lá se encontram. Os servidores estão em constante movimentação física, carregando processos, indo até o balcão para atender alguém que lá se encontra. A comunicação verbal é mais freqüente do que nos gabinetes. 


\subsection{A Representação Social do Sofrimento no Trabalho}

É aquele sofrimento íntimo, aquela insatisfação muito grande, aquela repressão daquilo que você está sentindo, daquilo que você está pensando e a frustração... Eu acho que é aquele sofrimento moral mesmo, de você vivenciar um estado de coisas e não poder alterá-las. E tem conseqüências emocionais e, conseqüentemente físicas, porque o emocional se reflete no físico... (Entrevista 19)

É uma coisa que você vai entrando, entrando, entrando e você acaba... (Entrevista 20)

Retoma-se a discussão do conceito de sofrimento a partir destas frases ditas por entrevistadas, nas quais é possível vislumbrar a relação que o sofrimento no trabalho mantém tanto com as situações e condições vivenciadas no cotidiano que impedem a pessoa de desenvolver seu trabalho da forma que julgar mais adequada à qualidade do trabalho e mais bem adaptada às suas necessidades momentâneas, quanto com a frustração de desenvolvimento de suas potencialidades e com a frustração das expectativas profissionais de desenvolvimento em longo prazo. E ainda que tal processo vai se desenvolvendo de forma insidiosa, ou seja, lenta e discretamente.

Neste capítulo, será apresentada a representação social do sofrimento no trabalho para os funcionários e dirigentes das secretarias e dos gabinetes da instituição em 
questão. A organização da representação social do sofrimento no trabalho tomou, neste trabalho, uma configuração constituída por três agrupamentos de sentido, nos quais se distribuíram as categorias. Uma das categorias apresenta subcategorias.

\section{Agrupamentos de sentido:}

- $\quad$ Elementos constitutivos do sofrimento no trabalho

- $\quad$ Elementos moderadores do sofrimento no trabalho

- $\quad$ Expressões do sofrimento no trabalho

As categorias pertencentes a cada agrupamento de sentido são as seguintes:

\section{Elementos constitutivos:}

- $\quad$ Injustiça no ambiente de trabalho;

- Volume cumulativo de trabalho;

- $\quad$ Não reconhecimento pelo trabalho;

- $\quad$ Falta de autonomia no trabalho;

- Estagnação profissional - Angústia da “Estaca zero”;

- $\quad$ Opressão por parte de superiores.

\section{Elementos moderadores:}

- C C C C $\quad$ itérios explícitos e adequados de avaliação e concessão de gratificação;

- $\quad$ Relações sociais positivas no ambiente de trabalho;

- $\quad$ Aprendizado no trabalho;

- Gerenciamento adequado do volume de trabalho por parte do desembargador e/ou do dirigente; 
- $\quad$ Estratégias de enfrentamento

o Distanciamento afetivo das causas dos processos;

o Desinvestimento no trabalho / Descomprometimento com o trabalho;

o Busca de outras oportunidades dentro da instituição - "articular”, “circular”, “pular de lugar em lugar”, “ser político”;

o Estudar para prestar concursos para carreiras jurídicas (Promotoria, Procuradoria e Magistratura);

o Investir afetiva e intelectualmente em dimensões da vida extratrabalho (família, por exemplo).

\section{Expressões do sofrimento no trabalho}

- $\quad$ Medo;

- $\quad$ Sentimentos de auto-desvalorização;

- $\quad$ Desesperança, desalento;

- Contaminação do pensamento e do sono por conteúdos do trabalho;

- $\quad$ Adoecimentos somato-psicológicos.

A seguir apresenta-se esquema sintético da representação social do sofrimento no trabalho para o grupo estudado: 
Figura 16 - Esquema Sintético da Representação Social do Sofrimento no Trabalho

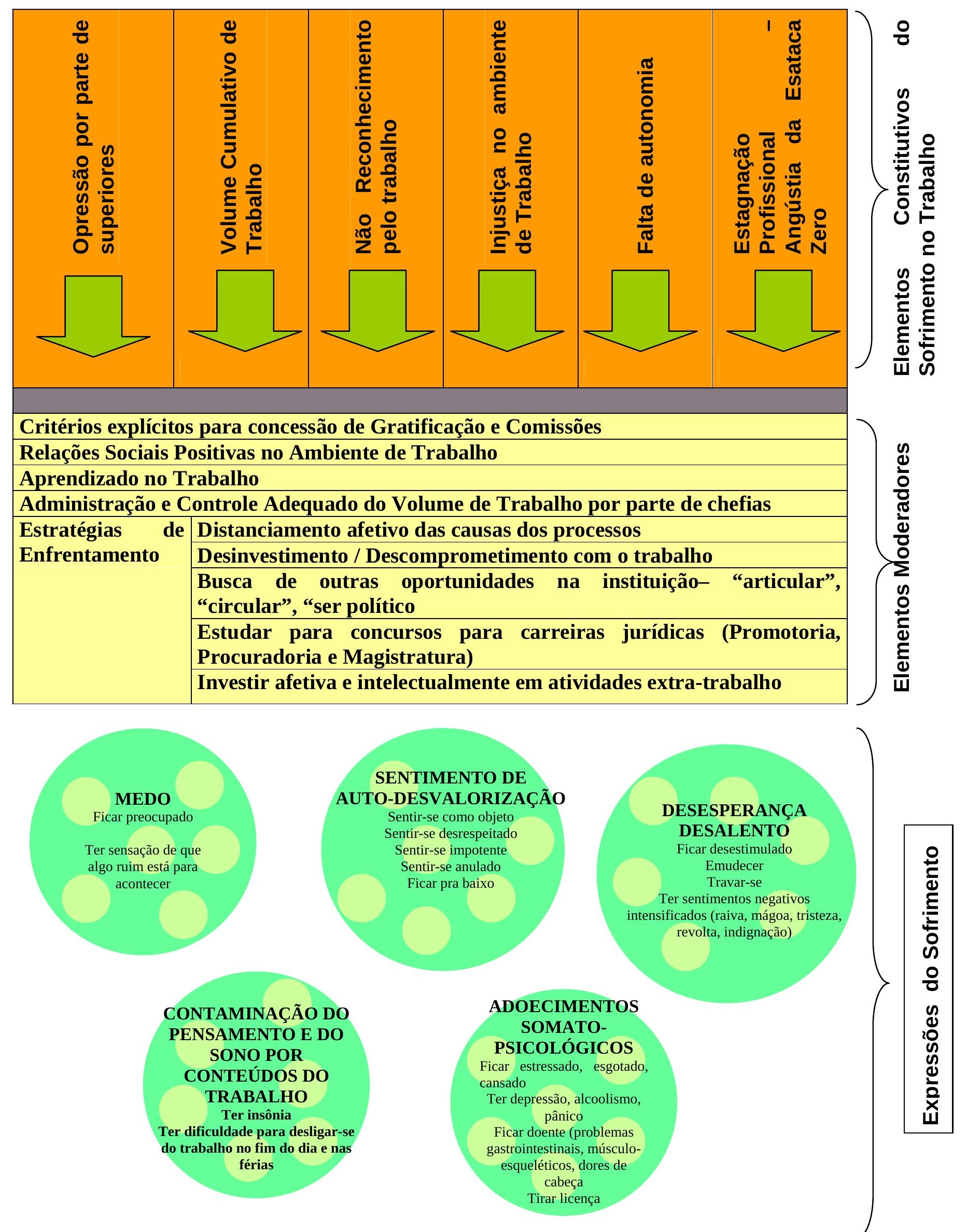




\section{ELEMENTOS CONSTITUTIVOS DO SOFRIMENTO NO TRABALHO}

Neste agrupamento de sentido estão os conteúdos que agregam os elementos do trabalho categorizados como aqueles que constituem o sofrimento no trabalho. Tais conteúdos foram identificados nas respostas diretas à questão sobre a existência do sofrimento no trabalho e ainda a elementos próximos semanticamente, como por exemplo:

isso chega a ser uma tortura pra pessoa

o que mais sobrecarrega emocionalmente

é desumano...

... causa muita raiva dentro das pessoas.

... então pra mim foi horrível

... e isso mexe com a gente

... causa um estresse

... você se sente mal

Então, dava uma sensação muito ruim pra gente

... um medo permanente...

Eu me sinto mal de ...

... causa uma certa angústia

... me sinto muito anulada, isso me revolta.

Você começa a sentir que está vivendo numa guerra fria

Aquilo ali é pra deixar qualquer um louco

... um desânimo, um nervoso... 
Parece que você tem até uma doença...

\section{A injustiça no ambiente de trabalho}

"Então, você vê por aí (dentro da instituição) pessoas ganhando um salário muito grande. E outras recebendo um salário de miséria... E fazendo, muitas vezes, a mesma função. Ou as vezes, aqueles que ganham menos, trabalhando muito mais do que aqueles que ganham mais.” (Entrevista 12)

A percepção da injustiça foi o aspecto mais relevante relacionado ao sofrimento no trabalho na análise das entrevistas, segundo critérios de freqüência e intensidade com que apareceu no discurso dos entrevistados.

“Ah! Eu sei, posso falar disso pessoalmente porque, como eu disse no começo da entrevista, eu passei por isso. Isso gera sim, gera muito sofrimento, porque existe aquela sensação de que você está sendo injustiçada a todo momento...” (Entrevista 19)

As situações identificadas como injustas relacionam-se a: (a) desigualdade salarial; e (b) desigualdade na atribuição de tarefas e responsabilidades entre os servidores e entre os diferentes setores da instituição. 
(a) A desigualdade salarial considerada injusta pelos entrevistados é aquela que ocorre entre pessoas que realizam as mesmas atividades ou atividades similares, recebendo salários diferentes. Tais desigualdades são variadas e ocorrem devido à existência de cargos comissionados e funções gratificadas. Dentre os cargos comissionados, encontram-se os de direção, chefia e assessoramento, os quais possuem atribuições específicas e diferenciadas dos demais funcionários. Já as funções gratificadas de assistente são distribuídas entre os funcionários, os quais, normalmente continuam a desenvolver as mesmas atividades anteriores, da mesma forma que os demais colegas de setor, que não dispõem de tal gratificação. A escolha dos funcionários que receberão as gratificações dá-se baseada em critérios utilizados para a concessão de gratificações. Um deles é a antigüidade e o outro é o merecimento, expressões próprias da instituição. Na categoria 'Critérios para a Concessão de Cargos e Funções Gratificadas', serão explicados cada um destes critérios, bem como as idéias a eles relacionadas pelos entrevistados.

E é uma injustiça... Como que eu vou falar? No momento em que você fala que tem 10 pessoas que fazem a mesma coisa e umas ganham o que pode ser até a metade das outras .... Eu acho que ... é uma injustiça, né. (Entrevista 31)

Tal como assinalado pelo entrevistado acima, em relação ao salário, a gratificação tem um valor bastante significativo, podendo corresponder a um aumento de cerca de 145\% de seu salário, para um funcionário de nível médio, que ocupe o primeiro nível salarial (ingressante), caso venha a receber a gratificação. Mesmo para um 
funcionário de nível superior, que ocupe o último nível salarial, o fato de passar a receber a gratificação pode aumentar seu salário em torno de $42 \%{ }^{6}$ É principalmente a esta diferença que as pessoas se referem quando falam sobre a injustiça no ambiente de trabalho. Sobretudo quando se trata de pessoas que exercem as mesmas funções, estas diferenças salariais são de difícil aceitação pelos funcionários e manejo problemático para parte dos diretores e chefes.

A situação pode trazer sofrimento tanto para quem recebe a gratificação quanto para quem não a recebe, pois a percepção da injustiça incomoda também aquele que não está sendo injustiçado, mas experimenta os sentimentos despertados pelo convívio com a injustiça em seu ambiente e pela possibilidade de vir a fazer parte deste grupo de funcionários considerados injustiçados. Esta possibilidade é melhor abordada na categoria estagnação profissional.

Você acha certo uma pessoa sentar do seu lado, fazer a mesma coisa que você e ganhar metade que você? Eu não acho certo. (Entrevista 20)

“... Eu tenho a verba porque foi tirada de outra pessoa. Foi complicadíssimo... Foi complicado. Aí eu me senti muito mal de ter, no começo, parecia que estava fazendo uma coisa errada, [parece que era] uma coisa que não era minha. (Entrevista 29)

\footnotetext{
${ }^{6}$ Estas proporções estão baseadas na tabela de vencimentos dos servidores das carreiras do Poder Judiciário, vigência 01/01/2000 (Conselho da Justiça Federal) e confirmam as impressões relatadas pelos entrevistados.
} 
No dia-a-dia de trabalho, este papel significativo das gratificações na remuneração traduz-se em tensões, conflitos pela posse da mesma, acirramento da competição, sentimentos de revolta, raiva, insegurança, desconfiança, discriminação, desestímulo, desmotivação, as vezes atribuíveis, equivocadamente, a desentendimentos pessoais.

(b) A desigualdade na distribuição das tarefas, por sua vez, reúne duas situações. Uma delas diz respeito à delegação de responsabilidades, de um patamar hierárquico superior para um inferior, dentro do mesmo setor, a qual recebe a qualificação de injusta quando é percebida como não correspondente às atribuições do cargo ocupado. Assim, as pessoas também se sentem injustiçadas quando a elas é delegada tarefa pertinente a cargo superior. Denominam-na injustiça pelo fato de estarem exercendo determinada função e outro receber o valor referente a ela.

“... quando você vê uma pessoa que tem um cargo em comissão, já aconteceu com a gente também, da pessoa encostar o corpo e passar tudo pra você, pros funcionários, e ela não fazer nada...” (Entrevista 36)

“... Há muita injustiça aqui dentro. Você tem pessoas não tão qualificadas em postos de direção, que não assumem a responsabilidade daquele cargo e transferem a responsabilidade para pessoas que as vezes não estão preparadas e nem recebem praquilo. (Entrevista 28) 
A outra situação relativa a distribuição de tarefas que origina injustiça é a carga de trabalho diferenciada entre setores, ou seja, quando o número de servidores por setores e a carga de trabalho neles mantém proporções inversas, em alguns setores:

“... As pessoas têm 50 ofícios pra expedir num dia e sem dar conta e correndo e não foi almoçar pra expedir e que ganham praticamente a mesma coisa e que vão por aí as vezes visitar alguém e tem um pessoal vendo revista, vendo e-mail... Entendeu? ... O funcionário se revolta...” (Entrevista 21)

Entre os setores, a distribuição da carga de trabalho se dá no nível institucional, enquanto que a delegação de tarefas e responsabilidades explicada acima ocorre entre os níveis hierárquicos de uma mesma subsecretaria, divisão ou gabinete.

A má alocação de espaços e funcionários no serviço público é uma questão levantada por DURAND e BELTRÃO (1994) como um fator que contribui para a ineficiência da instituição no cumprimento de sua missão.

A relevância desta categoria, a Injustiça, no discurso dos entrevistados nos remete, inevitavelmente, ao fato de os mesmos se dedicarem à atividade de auxiliar o juiz na aplicação da Justiça, sendo que a maior parte deles é formada em Direito (cerca de $90 \%$ dos entrevistados estuda ou estudou Direito). A configuração desta categoria do Sofrimento no Trabalho deste estudo parece guardar relação com o modo próprio de pensar e a linguagem do mundo da Justiça e do Direito, dos quais os servidores do Poder Judiciário, se apropriam enquanto instrumento indispensável à socialização e adaptação no meio de trabalho. 


\section{Volume cumulativo de trabalho}

“... porque você faz, faz, faz e você nunca vê o fim. Não chega ao final porque sempre vai chegando coisa nova.... A pessoa trabalha, chega antes do horário, vai embora depois e não está conseguindo dar conta do serviço e isso acaba estressando a pessoa mesmo.” (Entrevista 32)

“... aquela sensação de que nunca tem fim aquilo, que precisa dar mais e mais de si, embora já esteja dando o máximo. (Entrevista 19)

Uma sensação comumente citada pelos entrevistados é a sensação de impotência, a qual aparece relacionada primordialmente ao volume de trabalho, sendo este caracterizado pela demanda crescente pelos serviços do Poder Judiciário e pelos prazos de execução, na maioria das vezes irrevogáveis.

Importante é salientar que esta problemática adquire dimensões diferentes nos dois setores onde se deu o estudo. Nas secretarias, o volume de trabalho é caracterizado por ser predominantemente mecânico e repetitivo, para o qual consta normalmente um prazo para execução. Por exemplo, todos os documentos referentes a processos que estão sendo ou serão julgados por determinado desembargador, precisam ser analisados, 
conferidos e encaminhados ao gabinete correspondente. Assim como os processos, também as resoluções tomadas pelos juízes demandam providências executadas pelas secretarias e estas não podem ser adiadas. Disso resulta um ritmo de trabalho intenso e uma significativa queda da autonomia da pessoa para regular tanto o ritmo como a forma de execução das tarefas, gerando cansaço mental e físico.

Nos gabinetes, ainda que também exista a cobrança de prazos ou quantidade de processos a serem trabalhados semanalmente, o ritmo acaba sendo determinado em grande parte pelo funcionário, já que as tarefas dependem em graus variados de trabalho intelectual, vinculado a um ritmo individual. Assim, a cobrança de quantidade de processos gera ansiedade, tensão, mas não necessariamente ritmo intenso. Na maioria deles, é estabelecida pelo dirigente e/ou pelo desembargador uma meta quantitativa de processos a serem julgados semanalmente ou mensalmente, mas que não tem uma correspondência necessária com a entrada de processos, a qual é, pode-se dizer, invariavelmente maior do que a saída. Assim, a conjugação entre a demanda crescente e os prazos para execução tem um impacto maior nas secretarias do que nos gabinetes.

Nos gabinetes também foi relatado que o sentimento de responsabilidade pelo jurisdicionado, num contexto de grande acúmulo de processos, é fonte de sofrimento entre os funcionários, especialmente quando envolve pessoas físicas em situação de carência econômica. 
“... você vê aquelas pessoas que estão precisando, têm o direito e aquilo não anda! Por mais que você faça, aquilo não anda. Pela própria consciência da gente, fica complicado.” (Entrevista 1)

No que diz respeito a este aspecto do volume de trabalho gerador de sensação de impotência, as pessoas relataram ser tal sentimento mais intenso no início de sua vida profissional no Tribunal ou no Poder Judiciário. Assim, com o decorrer do tempo, têmse que as pessoas promovem um distanciamento afetivo do trabalho e percebem que individualmente não podem solucionar um problema que é estrutural do Poder Judiciário e que não depende somente do desempenho individual para ser resolvido. Tal tema será tratado mais adiante, na categoria ‘estratégias de enfrentamento’.

Por outro lado, demanda crescente, conjugada a uma estrutura considerada insuficiente para ela, acarreta um número cada vez maior de processos que se acumulam nas prateleiras, nas mesas e nos demais espaços possíveis. A este problema da falta de espaço físico para o armazenamento dos processos, os entrevistados identificam uma sensação penosa, que é a sensação de estar sendo "sufocado" por este volume crescente e sem perspectivas de ser vencido. Para os entrevistados, a visualização das pilhas de processo acaba por intensificar o sofrimento, na medida em que contribui para que a idéia do acúmulo de trabalho não abandone o campo da vivência imediata, do momento. Além disso, ter sempre à vista as pilhas de processo, parece dificultar o desenvolvimento do distanciamento afetivo citado na categoria 'estratégias de enfrentamento'. 
“... O que me incomoda tremendamente é aquele monte de processos dentro do gabinete, eu acho que aquilo te sufoca pra trabalhar. Eu acho uma coisa muito desagradável... Porque, por mais que você faça, você não vê diminuir a sua volta a quantidade de processos, então é como se você não estivesse fazendo nada.." (Entrevista 5)

Nas subsecretarias, é possível observar uma repercussão mais concreta desta conjugação entre o volume excessivo e o espaço inadequado e insuficiente, em que o acúmulo de processos acaba levando o funcionário a adotar posturas corporais desconfortáveis. Um dos entrevistados, ao falar sobre tal situação, ainda a considerou um mal menor dentre aqueles causados pelo volume de trabalho:

“... nem sempre a gente pode trabalhar numa postura ideal. Por quê? O que a gente faz? Por falta de espaço, a gente vai colocando as pilhas de processos em cima da mesa, no chão, do lado, tudo, então, você vai tendo que se adaptar no seu ambiente.” (Entrevista 2)

Um outro aspecto importante do volume de trabalho é a variabilidade sazonal da demanda pelo Judiciário. Assim, determinados acontecimentos políticos e econômicos podem acarretar um aumento enorme da demanda. Por exemplo, quando o Poder Executivo divulga uma nova medida provisória que pode vir a ser configurada como inconstitucional, gera uma grande demanda pela Justiça Federal. 


\section{O não reconhecimento pelo trabalho}

O trabalho é mediador de integração social, seja por seu valor econômico que propicia a subsistência, seja pelo valor simbólico, intervindo na constituição dos modos de vida, com a presença cotidiana e as relações sociais. É através dele que as pessoas realizam projetos de vida e sonhos. É nele ainda que as pessoas concentram seus esforços e objetivam suas capacidades e competências inerentes e adquiridas, ao longo de suas vidas. Através do trabalho, as pessoas esperam poder experimentar a sensação de que contribuem para a consecução de objetivos sociais e pessoais e de que se está aprimorando como profissional e pessoa.

A partir da análise das entrevistas, identifica-se que o não-reconhecimento pelo trabalho compõe-se da idéia segundo a qual o desempenho profissional do servidor não é considerado institucionalmente de forma suficiente, seja por não haver a prática cotidiana do retorno da avaliação da qualidade do trabalho, seja pelo fato de a qualidade do trabalho desenvolvido não ser sistematicamente levada em conta para promoções ou acréscimos salariais, em um plano de carreira. Tal aspecto é visto como algo que repercute no bem-estar das pessoas na medida em que frustra, em variados graus, o desenvolvimento das potencialidades profissionais individuais e as expectativas em longo prazo e que não proporciona à pessoa a vivência de ser valorizado por aquilo que faz.

Ao queixarem-se de que o desempenho profissional não é suficientemente considerado pela instituição, as pessoas salientam que outros fatores do rol de qualidades 
dos servidores acabam sendo mais determinantes no momento de uma nomeação para cargos em comissão. Estes outros fatores poderiam ser conceituados como capital de relações sociais, tal como utilizado por KFOURI (1992), ao se remeter a importância do papel das relações interpessoais na ascensão profissional e salarial de gerentes no serviço público.

“Os funcionários não são valorizados. Por exemplo, uma pessoa que trabalha muito, eu acho que ela vai perdendo o entusiasmo, porque não são esses os valores que contam. Tem muitas outras coisas que contam, é política, você fazer amizades com a pessoa certa, ser bem relacionado... O fato de você fazer o serviço, não é o que importa, você saber fazer o serviço direito. Então, eu acho que isso vai desmotivando as pessoas. (Entrevista 20)

“... não importa você pensar assim: 'Nossa! Tem tudo isso aqui, eu vou me organizar, vou fazer 100 processos hoje e não sei quê, ....' Você entendeu? Você nunca vai ser valorizado por isso. Entendeu?” (Entrevista 20)

Uma situação emblemática do não reconhecimento institucional pelo trabalho ocorre por ocasião da troca de desembargador em um gabinete ou na presidência. Vários relatos surgiram descrevendo tais situações, nas quais é comum a dispensa de funcionários, sobretudo aqueles que ocupam funções gratificadas para que estas passem a ser ocupadas por outros funcionários. Os funcionários dispensados buscam uma nova colocação dentro do Tribunal através do departamento de Recursos Humanos. Como tais 
funções são atribuídas a alguém pelo critério da confiança, é plenamente conhecido e previsto tal acontecimento. No entanto, para o funcionário dispensado, a perda da função gratificada ou do cargo comissionado significa uma ruptura na trajetória profissional dentro da instituição, um evento quase sempre negativo em sua vida, para o qual ele não encontra explicações no âmbito de suas atitudes e qualidades individuais, não estando a seu alcance, portanto, modificar tal situação.

“E também essa questão de verba, de gratificação, nem sempre a pessoa que realmente merece ${ }^{7}$, ela recebe, porque tem critérios outros, de amizade, de simpatia, que prevalecem sobre aquele que trabalha, que é eficiente no setor. Então, isso gera muita frustração.” (Entrevista 28)

Uma das entrevistadas mostra que durante as mudanças no quadro de funcionários, por ocasião da troca de desembargador do gabinete, se intensifica o sentimento de não valorização profissional. Evidencia-se a importância das relações interpessoais na escalada hierárquica em detrimento da dedicação e desempenho profissional:

“Então, [é como se eles dissessem]: ‘não quero nem saber se isso vai pegar mal pra você, se futuramente a coisa vai te prejudicar, se não vai, pra onde você vai, se vai

\footnotetext{
${ }^{7}$ Nesta fala aparece menção ao critério do merecimento, o qual é melhor explicado na Categoria Critérios de Avaliação de Pessoal e Concessão de Gratificações, no Agrupamento de Sentido Elementos moderadores do Sofrimento no Trabalho.
} 
pra lugar melhor, não queremos saber se você é bom, se trabalha, se não trabalha, não queremos saber...”' (Entrevista 12)

Embora a nomeação de pessoas externas ao quadro de funcionários concursados para cargos de chefia, assessoria e diretoria seja um procedimento previsto na Lei $\mathrm{n}^{\circ}$ 8.112, de 11/12/1990, que institui o Regime Jurídico Único dos Servidores Públicos Civis, quando isto ocorre, é o não reconhecimento pelo trabalho que se evidencia enquanto interpretação para o fato.

“... você dá o sangue, trabalha que nem um louco, é bom pra você, porque você está aprendendo inúmeras coisas, mas você trabalha muito e aquele reconhecimento que você esperava que viesse, não vem, porque vem alguém de fora.” (Entrevista 4)

O serviço público não apresenta políticas direcionadas para promover o bom trabalho. Mais adiante, no Agrupamento de Sentido 'Elementos moderadores', se verá que uma das estratégias de enfrentamento é o estabelecimento de contatos pessoais com outras pessoas do Tribunal com fins de conseguir outras oportunidades dentro da instituição, como cargos em comissão ou funções gratificadas. Esta estratégia é descrita pelos entrevistados de diversas formas: articular, circular, pular de lugar em lugar, ser político.

Em dissertação de mestrado sobre carreiras gerenciais no serviço público, KFOURI (1992) relata que a falta de reconhecimento pelo trabalho é reconhecida como 
uma das fontes de insatisfação de gerentes de órgãos públicos, os quais advogam a necessidade de divulgar suas realizações, estabelecer contatos com várias pessoas para que possam receber algum tipo de reconhecimento.

Vários relatos enfatizam ainda o não reconhecimento da sociedade, da mídia, do público que utiliza os serviços da Justiça, apesar da grande carga de trabalho existente:

“... eu acho que é a desvalorização que a imagem do funcionário público tem na sociedade. Você fala que você é funcionário público, o pessoal já lê na sua testa que você é vagabundo. Aí você chega aqui, tem um monte de serviço...” (Entrevista 21)

\section{Falta de autonomia no trabalho}

O tempo é um fator restritivo constante da autonomia do trabalho do servidor no Judiciário. Em decorrência da combinação do grande volume de trabalho com os prazos judiciais, a forma de execução e desenvolvimento das tarefas acaba por se restringir, tornando o trabalho, sempre que possível, mais mecânico e repetitivo. Em decorrência disso, é diminuída também a autonomia para regular o ritmo e as pausas para descanso.

Aqui o tempo é padrasto, ele judia muito mesmo. (Entrevista 3) 
Então, tudo é em cima de quantidade, de te cobrar rapidez e quantidade. Então, eu acho que esse sistema de trabalho estressa, porque é um sistema único pra pessoas que cada uma tem um ritmo pra fazer as coisas. (Entrevista 5)

Nos gabinetes, em que o trabalho exige maior concentração mental e intelectual, a imposição de metas quantitativas de trabalho, ou seja, a cobrança de análise de um determinado número de processos semanais e a divisão de trabalho obrigam alguns servidores a trabalharem apenas em processos com modelos já prontos, destituindo-os do trabalho de elaboração e diminuindo sua autonomia no desenvolvimento da tarefa.

Essa autonomia é ... do diretor deixar o funcionário trabalhar da forma dele. (Entrevista 19)

Esta frase dita por um diretor de divisão de subsecretaria demonstra uma das faces da autonomia descrita pelos entrevistados, que é a liberdade concedida pelo chefe para que o servidor execute a tarefa de acordo com seu modo de ser, necessidades e estado momentâneos.

No entanto, notou-se outros aspectos da autonomia no trabalho cuja falta também foi relacionada ao sofrimento no trabalho na fala dos entrevistados.

SATO (1991), ao identificar a representação social do trabalho penoso para motoristas de ônibus, obtém que os contextos de trabalho sentidos como penosos são aqueles sobre os quais o trabalhador não tem controle para ajustar as demandas e as atividades. O controle sobre o contexto de trabalho e as atividades mostrou ser determinado por três elementos: o poder (determinado a partir da estrutura 
organizacional), a familiaridade (o conhecimento do contexto de trabalho e sobre si mesmo naquele contexto) e o limite subjetivo (o grau em que a pessoa suporta tal situação).

No contexto do grupo estudado, ocorre restrição do controle do servidor em relação ao trabalho tanto pela restrição do poder investido nos cargos quanto das regras e norma formais.

Mais profundamente, a falta de autonomia também se mostra nas entrevistas em aspectos estruturais do Judiciário. O formalismo, próprio dos procedimentos de trabalho no Judiciário, torna mais rígidos os padrões de cumprimento das tarefas, deixando pouca margem a criações e modificações nos procedimentos de trabalho.

Há relatos de freqüentemente serem realizados pelos servidores procedimentos considerados pelos mesmos dispensáveis ou desadaptados às demandas de trabalho momentâneas, sem a possibilidade de modificá-los. O funcionário não tem autonomia para interferir nos procedimentos do trabalho, ainda que muitas vezes seja considerado que tenha experiência suficiente para tal. O excesso de formalismo e a resistência em se promover mudanças no ambiente do Judiciário já foram considerados como elementos problemáticos ao bom funcionamento da justiça (DALLARI, 1996; ARAGÃO, 1997). Estes dois últimos aspectos podem provavelmente não ser restritos ao Poder Judiciário, mas ao serviço público em geral.

Também aqueles que ocupam posições de direção ou chefia relataram ter suas decisões, ainda que baseadas nas regras vigentes, sempre submetidas ao aval dos juízes, tendo estes, algumas vezes, a ação de anular regras ou normas institucionais. Assim, um dos entrevistados coloca que o arbítrio individual dos juízes prevalece sobre as regras 
estabelecidas, o que dificulta enormemente o trabalho destes, já que qualquer decisão tomada por eles pode ser invalidada, a depender de uma decisão, nem sempre de comum acordo.

Impossível trabalhar num lugar assim, em que vale o 'meu’ humor e não importa a regra. Mas isso aqui vive de regra, teoricamente. (Entrevista 37)

Muitas vezes, o desembargador acaba ocupando também o papel de superior administrativo em cada turma, fazendo com que o diretor de turma fique duplamente subordinado, ao diretor da secretaria judiciária e ao desembargador, no que diz respeito à organização do trabalho. A centralização administrativa também foi relatada em estudo sobre os fatores relacionados à lentidão de atuação da Justiça do Trabalho no Espírito Santo (ARAGÃO, 1997).

O papel de definição da autonomia (ou falta dela) no dia-a-dia dos servidores oscila entre estes dois elementos: as normas da instituição e o grau de poder de quem ocupa o cargo. 


\section{Estagnação profissional - a “angústia da estaca-zero"}

Na verdade a carreira do funcionário público é uma carreira ingrata, porque você não cresce nela. Você começa funcionário público, você morre funcionário público fazendo exatamente aquilo. (Entrevista 21).

A inexistência de um caminho formal de desenvolvimento de carreira dentro da instituição apresentou-se como a idéia principal à qual estava ligada a categoria da estagnação profissional, enquanto geradora de sofrimento. Através de variadas situações, os entrevistados descreviam os sentimentos experimentados: indignação, insegurança e desestímulo.

Como já visto, a ascensão profissional só pode ocorrer através de concurso público ou mediante nomeações para cargos em comissão e funções gratificadas. Tais nomeações são prerrogativas do magistrado, sob as condições de confiança e livre exoneração, ou seja, dependem de um critério subjetivo e particular do magistrado e podem ser retiradas a qualquer momento. Esta é uma relação de trabalho existente no funcionalismo público. Apesar do acréscimo salarial significativo decorrente de uma nomeação, mesmo que para assistente, a posição profissional do nomeado é incerta e de fato mostra-se inconstante no decorrer do tempo, conforme as inúmeras histórias relatadas pelos entrevistados.

Assim, são comuns os casos de pessoas que já ocuparam funções de chefia, assessoramento e direção por um determinado período, ao fim do qual, no entanto, voltaram a seus cargos e tarefas anteriores. A instabilidade da posição profissional e a 
eterna possibilidade de voltar à estaca-zero são uma importante categoria explicativa do sofrimento no trabalho.

Então, por exemplo, eu fui assessor, fui diretor, assumi posto de comando e ... agora lá eu estou bem, não estou me queixando agora, mas no futuro, posso, de repente ... ser colocado pra carregar processo. Isso é possível aqui. (Entrevista 28)

"Pô, mas voltar à estaca zero?” É uma coisa que também causa uma certa angústia. (Entrevista 28)

Um dos fatores desta alta rotatividade nos cargos e funções gratificadas é que a cada 2 anos, ocorre mudança de presidência do Tribunal, provocando mudanças nos setores mais diretamente atrelados aos magistrados.

“... sobem e descem cabeças... todo mundo fica pisando em ovos...” (sobre a situação de mudança de presidência, que ocorre a cada 2 anos) (Entrevista 10)

Também há mudanças nas funções gratificadas com a mudança de desembargador no gabinete, em casos de falecimento, aposentadoria ou promoção do desembargador anterior para outra instância da Justiça. 
“Você passa stress quando vai mudar juiz, a gente não sabe se o juiz vai por todo mundo em disponibilidade. Então, essas coisas, essa insegurança, você se sente um pouco inseguro.” (Entrevista 36)

Além da insegurança, os entrevistados vivenciam o sentimento de estarem sendo usados. Este sentimento é explicado pelos entrevistados pelo fato de o Tribunal contar com seu desempenho no trabalho, mas, a despeito da qualidade que seu trabalho possa apresentar, ele pode ser dispensado de um setor e ser colocado a disposição para ser inserido em outro setor. De certa forma, precisa recomeçar sua trajetória de trabalho dentro da mesma instituição, reconstruir as relações com os novos colegas de trabalho e com novas chefias, reconstruir o modo de trabalhar.

A respeito da conseqüência de tal instabilidade funcional neste contexto de estabilidade no emprego, aqueles que recebem a gratificação pela função de assistente têm um medo constante de vir a perdê-la, pois tal perda representa um retrocesso na trajetória profissional e, principalmente, salarial. A perda da gratificação, por seu valor significativo em relação ao salário, como já visto, acarreta uma desestruturação financeira, pela acentuada diminuição do poder aquisitivo. Esta é vista como a principal repercussão da estagnação profissional, pois altera o padrão de consumo e, conseqüentemente a vida pessoal e familiar do indivíduo.

“Eu convivo com uma pessoa que a gente percebe claramente que é um sofrimento mesmo. Ela fica com um medo permanente de perder essa gratificação.” (Entrevista 29) 
Nesta situação, o servidor queixa-se de não conseguir conquistar uma posição, ao invés disso, está sempre na dependência do arbítrio do desembargador.

Por outro lado, aqueles que nunca tiveram esta oportunidade sentem-se desestimulados no trabalho, privados de uma oportunidade de viver novas situações e enfrentar desafios no trabalho, permanecendo confinados a uma rotina de trabalho sem perspectivas de mudança:

E eu converso as vezes com pessoas que não vêem perspectivas e que se sentem um zero a esquerda, não tem incentivo, então... (Entrevista 22)

A estagnação profissional enquanto categoria da representação do sofrimento no trabalho mostrou-se significativa para servidores que ocupam funções gratificadas e cargos comissionados e também para aqueles que não os ocupam. Tanto dirigentes como servidores vêem-se estagnados profissionalmente, com a diferença de que aqueles que ocupam ou ocuparam cargos de chefia ou direção tiveram ou têm uma oportunidade transitória de viver novas experiências profissionais. 


\section{Opressão por parte dos superiores}

Segundo o dicionário da língua portuguesa Novo Aurélio, o termo opressão pode significar, entre outras coisas: abatimento de forças, prostração; vexame, humilhação (FERREIRA, 2000).

A opressão relatada nas entrevistas tem como agentes descritos tanto magistrados quanto servidores em posição de chefia, direção ou assessoria, e ocorre sob a forma de repreensão excessiva, podendo configurar-se como mal-trato, punição e humilhação do servidor quando este comete erros; exigências de produtividade tendo como base a ameaça declarada ou não, controle restritivo sobre a comunicação e expressão dentro do ambiente de trabalho e sobre a necessidade de ausentar-se da mesa de trabalho para ir ao banheiro, ir almoçar ou fazer pausas de descanso durante a jornada.

As expressões utilizadas para qualificar tais situações podem ser exemplificadas pelas seguintes: desrespeito; trabalhar sob clima de chicote nas costas e (o trabalho) acaba virando uma tortura.

Alguns trechos de falas podem ilustrar melhor tais idéias:

“... fazer com que a pessoa trabalhe muito, se fizer errado, ela é ridicularizada na frente das outras pessoas.” (Entrevista 12)

“... quando você tem uma exigência muito grande de trabalho, você tem que produzir aquilo de qualquer jeito, é uma ameaça.... eu já passei por isso, do tipo: 'Se vocês não fizerem ....'-deixava nas entrelinhas assim, -'‘. vão ser tomadas as 
providências.' E a gente tem conhecimento de outras pessoas que passam por situações até piores.” (Entrevista 36)

Eu acho que é uma forma de cobrança muito pesada, você não poder expressar as suas opiniões... Eu me sinto muito anulada, e isso me revolta, de uma certa forma, causa indignação. Causa uma séria indignação. Daí, somatizar e ter um problema físico, não custa. (Entrevista 23)

As vezes eu acho que eles ficam muito em cima das pessoas, regulando horário, não pode conversar, não pode comer, não pode ... O horário, você tem que sair tal hora e voltar tal hora exata, senão você vai ser descontado, vai ter algum problema... Acaba ficando uma tortura, você ter que ir. (Entrevista 29)

Na maior parte das vezes em que este tema surgiu nas entrevistas, referia-se a um momento anterior na história profissional dentro da instituição. Isto pode ser atribuído, além de ao receio compreensível de declarar na entrevista, também à possibilidade existente no Tribunal de remanejamento do servidor insatisfeito para outro setor, através do departamento de Recursos Humanos. Assim, aqueles que vivenciam tais situações podem solicitar remanejamento para outros setores. No entanto, a política de remuneração das gratificações contribui, mas não somente ela, para que servidores em condição de privilégio salarial (que têm a gratificação) que estejam, ao mesmo tempo, vivenciando situações indesejáveis em seus setores, não procurem auxílio para mudarse, pois com isso perderiam suas gratificações. 
Os entrevistados relacionam o comportamento opressivo de alguns dirigentes e magistrados à tensão vivida por estes últimos no desempenho de seus papéis profissionais, seja de desembargador, seja de dirigente. Muitas vezes, pode não haver meios ou ainda esses podem não estar preparados, reagindo inadequadamente, com reflexo no ambiente de trabalho e nos servidores.

“Tem juízes que, eu acho que eles não são realmente talhados pra função. Então, a pessoa fica mais estressada, sofre mais a pressão do advogado, ela se desestrutura mais ... ela pode ficar mais desestruturada.” (Entrevista 20)

Se surge um problema, seja ele da ordem que for, o administrador tem que resolver, sem se explodir, ou ficar irritado, tem que resolver o problema. (Entrevista 31)

A centralização do poder foi também um dos motivos levantados para tal fato.

O mal-estar que toma forma nas relações sociais do trabalho vem sendo estudado sob múltiplos pontos de vista e a partir de vários conceitos. Uma corrente que vem obtendo bastante destaque é aquela que se constrói a partir do conceito de assédio moral no trabalho, com os estudos de HIRIGOYEN (2000; 2002). Em alguns aspectos, os resultados obtidos neste estudo apontam para a necessidade de se estudar este ambiente sob esta perspectiva. 
A idéia de sofrimento no trabalho se encontra ligada, entre outros aspectos, à opressão vivenciada no ambiente de trabalho, descrita anteriormente. Pode-se ainda identificar determinadas características do contexto de trabalho na instituição como propiciadoras do assédio moral (HIRIGOYEN, 2002), que seriam as políticas de gestão de pessoas pouco claras (como por exemplo, a ausência de critérios explícitos e únicos na instituição para a avaliação dos servidores e a concessão de gratificações), o volume de trabalho que se acumula e sobrecarrega desigualmente alguns servidores e alguns setores.

\section{ELEMENTOS MODERADORES DO SOFRIMENTO NO TRABALHO}

Além dos elementos constitutivos do sofrimento no trabalho, um conjunto de aspectos foi igualmente encontrado, os quais se explicam enquanto amenizadores da intensidade com que é sentido tal sofrimento, a medida em que representam uma alternativa ou compensação para o sofrimento da pessoa e em que alimentam a esperança na modificação daqueles elementos que constituem-no.

No discurso dos entrevistados, os elementos moderadores apareceram sempre ligados a elementos semânticos de condição, compensação, dependência:

"tudo depende da...”;

"se a pessoa estiver num ambiente que ...";

“mas também, por outro lado....”;

"é relativo isso, porque ..."; 
“nós tínhamos esse problema, mas o que compensava era ...”.

Estas foram as condições, na análise dos dados, para a inclusão no agrupamento de sentidos dos "Elementos Moderadores".

\section{Critérios explícitos e adequados para a concessão de gratificações e comissões}

Esta categoria se justifica pelos critérios adotados para a concessão de cargos comissionados e funções gratificadas aos servidores.

Formalmente, cabe ao desembargador decidir a quem serão concedidos os cargos em comissão e as funções gratificadas. Segundo os entrevistados, na prática, isto é feito em geral conjuntamente pelo desembargador e pelos dirigentes. Os critérios explicitados nos diferentes setores de trabalho e citados nas entrevistas foram a antigüidade e o merecimento pelo trabalho. Ambos tiveram vantagens e desvantagens colocadas pelos entrevistados. Segundo esses, o critério da antiguidade é visto como o mais objetivo, no entanto, ignora o mérito dos funcionários (por exemplo, a produtividade), não cumprindo papel de estimular para o trabalho. Já o critério do merecimento, na visão dos entrevistados, apesar de contemplar o aspecto da produtividade e empenho do funcionário, não é tão objetivo, permitindo interpretações e avaliações variadas, podendo gerar disputa, insegurança e conflitos.

Conhecer os critérios adotados para se conceder funções gratificadas é visto como amenizador do sofrimento gerado pela injustiça da desigualdade salarial no ambiente de trabalho. O grau de objetividade do critério também é levado em conta. 
“... o maior problema é que a gente não sabe qual é o critério, porque se você tem um critério claro...” (Entrevista 4)

Por outro lado, o rompimento com um determinado critério que tenha sido estabelecido num determinado setor, ou seja, a exceção feita à regra, tem um efeito negativo quanto à percepção das injustiças no ambiente de trabalho.

Uma outra idéia relativa a isto surgiu no discurso dos entrevistados, a qual diz respeito ao fato de que, à parte os critérios utilizados, a situação de injustiça é inerente a esta política salarial, em que pessoas que desenvolvem trabalhos semelhantes na mesma instituição recebem salários tão díspares (ver Categoria Injustiça no Ambiente de Trabalho). Mesmo a diferença no desempenho individual não explicaria tais diferenças. A premiação por antiguidade, se assim fosse, de fato, seguiria uma progressão lógica salarial e não permitiria que exceções fossem feitas.

Assim, estabelecer critérios para a concessão das gratificações contribui para a manutenção da falsa idéia de que existe uma lógica justa por trás desta forma de remuneração e “premiação”, que tornam os salários tão díspares.

Por outro lado, a própria existência desta forma de remuneração, as funções gratificadas, que, como se viu diferencia o salário de pessoas que fazem praticamente o mesmo trabalho, é também questionada pelos entrevistados. Mas, apesar de acharem que estas não deveriam existir, não crêem na extinção delas. 


\section{Relações sociais positivas no trabalho}

Anteriormente ficou claro que a política de remuneração é vista como um importante elemento de influência sobre as relações entre as pessoas dentro do ambiente de trabalho, no sentido de incitar competições, inimizades, desconfiança e tensão em geral.

No entanto, outros elementos também foram citados como importantes influenciadores da forma como se dá o relacionamento entre as pessoas no ambiente de trabalho, podendo contribuir inclusive no sentido de amenizar o sofrimento. Tais elementos podem ser inumeráveis e de variadas denominações. Um dos elementos, o que mais agrupou significados do grupo de entrevistados, é a história de convivência do grupo de trabalho. Se determinado grupo de funcionários possui, em sua história coletiva, registros de convívio harmonioso no passado, sob o comando de um outro desembargador, sob outras regras, ainda que na atualidade exista uma situação desfavorável em relação ao ambiente de trabalho, o grupo tende a manter um nível mínimo de harmonia e equilíbrio. Assim, se houve um clima de trabalho sob regras que incitassem à cooperação, amizade e união entre os servidores, no decorrer da convivência de trabalho, durante um determinado período, mesmo ocorrendo mudanças neste ambiente de trabalho que intensifiquem os elementos constitutivos do sofrimento, esta harmonia e equilíbrio tendem a se manter e atuar como amenizadores do sofrimento.

Mas se, ao contrário, não houve este histórico de convívio harmonioso no passado, é suposto que a equipe de trabalho não consiga, com os próprios recursos 
coletivos, vencer os conflitos originados na competição pelas gratificações, sob regras internas que incitem à competição e à hostilidade pessoal. Nesta situação, o sofrimento é intensificado.

Nosso gabinete é até equilibrado, não tem problemas de ... Por mais equilibrado que seja, cria um certo desconforto, essa questão das verbas (gratificações). Por quê? Eu diria que nós nos damos muito bem, nosso grupo. Sempre nos demos bem. O grupo de trabalho, que trabalhamos junto desde a época do (...) (Entrevista 31)

A experiência passada de um ambiente de trabalho harmonioso vivido em comum não é considerada condição única para que a equipe supere as dificuldades atuais, mas apenas um dos elementos que contribui em algum grau para que seja amenizado o sofrimento gerado pela injustiça, pelo não reconhecimento pelo trabalho, pelo volume cumulativo de trabalho, pela estagnação profissional, pela falta de autonomia. Em outras palavras, um convívio considerado satisfatório ou vivenciado como suporte social pode ser um elemento de apoio.

“... mas se você tem um clima bom de trabalho, uma equipe legal, uma equipe que está coordenada, que tem um ambiente bom de trabalho, isso (impossibilidade de ascensão) não te pesa tanto, porque você sabe, a estrutura é essa, mas se você está em meio a pessoas boas, que valem a pena, que você tem um convívio bom...” (Entrevista 4) 
“... tudo vai depender do ambiente de trabalho que você fica. Não o trabalho propriamente, mas o clima. Acho que, se você trabalha sob pressão, se é um clima de competitividade, se é um clima onde não existe harmonia, onde não existe aquela confiança mútua entre as pessoas, principalmente da hierarquia superior em relação aos funcionários, isso pode causar muitos problemas...” (Entrevista 19)

Na determinação deste elemento moderador, o desembargador, bem como os dirigentes, foram citados como figuras centrais no clima do ambiente de trabalho. Por este motivo, este elemento moderador é visto como freqüentemente ineficiente no caso da opressão por parte de superiores (elemento constitutivo do sofrimento no trabalho).

“... o juiz reflete muito na chefia, na assessoria, o gabinete é um reflexo do juiz. Então, quando é uma pessoa assim difícil de se conviver, acaba passando, é uma pirâmide, vai passando...” (Entrevista 20)

No clima de trabalho, das relações que se estabelecem entre as pessoas, os colegas não são vistos individualmente como determinantes, como ocorre com os dirigentes e desembargadores. 


\section{Aprendizado no trabalho}

O interesse em aprender no trabalho foi citado freqüentemente nas entrevistas, principalmente por aqueles servidores pertencentes aos gabinetes.

Tal como a frase abaixo ilustra, a possibilidade de aprender no desenvolvimento das atividades de trabalho é vista como um elemento de compensação pelo sofrimento no trabalho causado pela injustiça no ambiente de trabalho, pelo volume cumulativo de trabalho e pela estagnação profissional. A possibilidade de aprendizado foi explicada como difícil de ocorrer juntamente com a opressão por parte de superiores, com o nãoreconhecimento pelo trabalho e com a falta de autonomia, já que nestas situações, as pessoas não teriam a liberdade suficiente para organizar seus afazeres, de forma a possibilitar o aprendizado.

"Apesar de ter esse lado (da injustiça na concessão de gratificações), eu me sentia assim gratificada pelo fato de estar podendo aprender bastante lá, né." (Entrevista 12)

A conjugação entre um ambiente em que há possibilidade de aprender no trabalho e um funcionário interessado no aprendizado compõe um elemento amenizador do sofrimento.

Por outro lado, um funcionário com tal demanda, mas que trabalhe em um ambiente em que esta possibilidade não existe, pode ter seu sofrimento intensificado. 
É importante destacar que o desejo de aprender no trabalho mostrou-se muito ligado ao plano de sair do Tribunal por intermédio de concursos públicos na área jurídica. Tal plano, como será visto, é uma das estratégias utilizadas para moderar o sofrimento no trabalho. Para os entrevistados, quando há esta expectativa de prestar concursos públicos, o trabalho no Tribunal é considerado uma fase passageira na vida profissional do servidor e ainda uma oportunidade de aprendizado.

Adicionalmente, independente do desejo de prestar concursos ou permanecer na instituição, o aprendizado no trabalho também foi citado como elemento de satisfação pelos entrevistados.

Dentro do Tribunal, os entrevistados classificam que os gabinetes seriam os ambientes ideais para o aprendizado na área jurídica. E o contexto de trabalho ideal seria aquele em que os dirigentes dividissem o trabalho de tal forma que os servidores pudessem desenvolver todas as tarefas concernentes aos processos. Assim, haveria maior chance de todos trabalharem em processos mais complexos ou que exijam pesquisa, raciocínio e desenvolvimento de novos modelos de análise e argumentação.

Ao analisar estudos sobre o trabalho no serviço público em geral, nota-se não ser freqüente a citação deste contexto de trabalho enquanto possibilidade de aprendizado.

Esta categoria sugere um contexto de trabalho, sobretudo nos gabinetes, com possibilidade de ir além do que é comumente descrito como característico do serviço público, de ser apenas um trabalho com tarefas maçantes, repetitivas e monótonas. Na verdade, ele se mostra como um espaço de contato com material rico do campo do Direito, de desenvolvimento profissional, no sentido de aprendizagem e aquisição de experiências. 


\section{Gerenciamento adequado do volume de trabalho por parte do desembargador e/ou do dirigente}

Mesmo naqueles locais em que o volume de trabalho é maior, foi creditada grande importância ao papel que a direção do setor desempenha no controle e organização desse volume, quanto à moderação do sofrimento causado pelo volume cumulativo de trabalho.

O gerenciamento adequado do volume de trabalho se obtém traçando estratégias para reduzir o volume, simplificando o processo de trabalho, estabelecendo critérios de prioridade para os processos, organizando os processos de forma lógica, de modo a serem facilmente identificados e encontrados, orientando os funcionários em suas dúvidas. Para tais feitos, a experiência de trabalho do dirigente é de fundamental importância. Os entrevistados creditam esta qualidade, em primeiro lugar, àqueles dirigentes originários do quadro de servidores concursados ou que pelo menos tenham experiência em um outro órgão da Justiça Federal.

Gerenciar adequadamente o volume de trabalho, muitas vezes, significa promover mudanças na organização do trabalho ou nos procedimentos. Mudar a organização do trabalho ou os procedimentos é descrito pelos dirigentes e por alguns servidores ora como um estimulante desafio, ora como algo impossível, cuja busca é extenuante e desalentadora.

Pela incompatibilidade da demanda com estrutura e procedimentos, tal como salienta a literatura judiciária, as instituições do Judiciário carecem de mudanças. Isto é um desafio para seus diferentes grupos profissionais. No entanto, há também uma 
grande resistência a mudanças nos procedimentos de trabalho, na visão dos entrevistados.

Dois ou três entrevistados descreveram episódios em que, individualmente ou em conjunto, alcançaram a modificação de algum procedimento de trabalho no sentido de otimizá-lo ou aperfeiçoá-lo. Para isso, passaram sempre por um longo processo o qual uma das entrevistadas chamou de convencimento da autoridade, o que significa dizer, mostrar ao magistrado, através de dados, explicações verbais e relatórios, que a modificação do procedimento de trabalho é conveniente para a instituição.

No entanto, a maior parte descreveu tentativas infrutíferas de modificações, não aprovadas pelos dirigentes ou pelos magistrados, sugerindo dificuldades em se avaliar as repercussões de modificações, pela complexidade do trabalho.

Vale diferenciar as mudanças na organização do trabalho e nos procedimentos daquelas concernentes a estruturação dos órgãos do Poder Judiciário (como já visto em item sobre o histórico sobre o Poder Judiciário) e concernentes à redistribuição de atribuições entre setores ou instâncias. ASSUNÇÃO e cols (1998) apontam que as mudanças decorrentes destas reorganizações de variados âmbitos dentro do Poder Judiciário afetam direta ou indiretamente o cotidiano de trabalho, causando, muitas vezes, desgaste maior aos servidores, dirigentes e desembargadores.

Em estudo em Fórum da Justiça Estadual Mineira, RIGAMONTE (1998) também constatou a importância da chefia na exacerbação ou diminuição do sofrimento do servidor. 


\section{Estratégias de enfrentamento}

A categoria das estratégias de enfrentamento diz respeito às formas com que as pessoas re-concebem o trabalho em suas vidas, como lidam com as situações ou elementos do trabalho que os levam ao sofrimento, de modo a minimizá-lo ou ainda transformá-lo.

As estratégias podem envolver tanto ações práticas que ocorrem na situação cotidiana de trabalho, quanto uma re-significação do trabalho em suas vidas.

Assim, o desinvestimento no trabalho envolve tanto uma mudança na ação prática, do dia-a-dia de trabalho, que é a de fazer o menos possível, quanto uma resignificação do trabalho, que é a de desconsiderar a importância do trabalho enquanto atividade principal diária, redirecionando suas expectativas e esforços para outras esferas da vida. Também a estratégia de estudar para prestar concursos para carreiras jurídicas implica tanto na ação prática de buscar oportunidades de aprendizado dentro do Tribunal (que possam ser aproveitadas em seus estudos para os concursos, escolhendo processos mais difíceis para trabalhar), quanto na re-significação do atual trabalho como algo passageiro, como uma ponte para outros caminhos profissionais (que podem ser a magistratura, a promotoria, a procuradoria ou outros cargos jurídicos).

As estratégias não são excludentes, ou seja, mais de uma estratégia pode ser utilizada pela mesma pessoa.

Serão apresentadas, a seguir, as principais estratégias identificadas neste estudo. 


\section{Distanciamento afetivo das causas dos processos}

Esta estratégia é citada como forma de amenizar o impacto do enorme volume de processos que chegam diariamente ao Tribunal e que se acumulam nas prateleiras, nas mesas, em pilhas no chão, nas cadeiras, nos móveis e nos corredores.

O incômodo causado por este aspecto diz respeito ao fato do funcionário sentirse, de alguma forma, responsável pelo desenrolar dos processos. Tal situação se aplica especialmente aos gabinetes que respondem por matérias que tratem de interesses de pessoas físicas em situação de carência. A experiência dos funcionários assinala que, com o decorrer do tempo, as pessoas promovem um distanciamento afetivo do trabalho e desenvolvem argumentações para não mais se sentirem responsabilizadas pelos processos.

Embora haja o esclarecimento de que individualmente não poderiam solucionar um problema que é estrutural do Poder Judiciário, e que, portanto, não são responsáveis pelo acúmulo de processos nas prateleiras, ocorre um envolvimento natural com as causas dos processos, com a busca de solução e justiça, contra o qual a pessoa desenvolve esta estratégia, como forma de preservação do bem-estar.

"Se você começar a viver o problema de todo mundo que vem aqui, você vai acabar em depressão, vai acabar se internando em um hospício, porque você vai ficar louco, você vai ficar louco! ... E você vê que é uma bola de neve, a coisa vai aumentando, aumentando, aumentando, e fica complicado. Aí você fala: "Eu vou e a 
coisa vai ficar". Então, é muito difícil, lidar com essas coisas todas é muito difícil mesmo.” (Entrevista 12)

Este distanciamento foi caracterizado pelos entrevistados pela justificação racionalmente construída sobre a causa estrutural do acúmulo de processos e pela impotência do servidor diante disto. Esta estratégia não envolve ações de distanciamento das tarefas de trabalho e nem descomprometimento com o trabalho, mas sim, uma resignificação do trabalho desenvolvido no que tange a idéia dele como distribuidor de justiça.

Sobre este aspecto, foi feita uma comparação com o trabalho do médico. Este, pelo envolvimento com pessoas doentes, tenderia a manter-se distante afetivamente para não sofrer juntamente com o paciente.

\section{Desinvestimento no trabalho / Descomprometimento com o trabalho}

Diferentemente do distanciamento afetivo das causas dos processos, o desinvestimento ou descomprometimento está relacionado a qualquer das categorias constitutivas do sofrimento no trabalho e envolve modificação na ação de trabalho, no sentido de promover o não envolvimento com tarefas complexas ou problemáticas, o desinteresse pelas atividades de trabalho em geral e/ou uma queda no rendimento.

As injustiças no ambiente de trabalho, o não reconhecimento, a estagnação profissional, o volume cumulativo e a opressão por parte de superiores estão 
relacionadas a um sentimento de desesperança. Este sentimento de desesperança pode implicar, para o indivíduo, no desinvestimento de seus esforços no trabalho e um descomprometimento com as atividades em curso.

A injustiça no ambiente de trabalho é a categoria mais relevante na assunção desta estratégia de enfrentamento. Tanto aqueles que se sentem injustiçados por não disporem de funções gratificadas, quanto aqueles que dispõem dela podem vir a utilizála, segundo a experiência dos entrevistados.

"Eu percebo isso claramente, com o passar do tempo, vai acontecendo o seguinte, você fala assim: Ou eu fico e fico totalmente apático, não me interesso mais, finjo que me interesso pelo serviço ou eu saio e vou fazer outra coisa. As pessoas que têm mais qualificação, se esforçam mais, elas vão saindo e vão procurando outras coisas. Ou então, você fala assim: Ah, eu fico, eu me acomodei, eu acho que eu tenho um salário razoável...” (Entrevista 20)

Alguns estudos já demonstraram que a acomodação e o trabalhar pouco são elementos que constituem a representação existente acerca do funcionário público (VENEU, 1990; FRANÇA, 1993). As idéias de desinvestimento e descomprometimento relacionadas ao sofrimento não levantam, necessariamente, a mesma idéia. É possível descomprometer-se ou desinvestir os esforços, e permanecer cumprindo deveres, realizando tarefas necessárias no trabalho. O que entra em jogo é a capacidade e potencialidade para desenvolver-se profissionalmente, aprender, envolver-se no trabalho e em todas as tarefas. Outra diferença é que aqui, a idéia aparece como uma construção 
para lidar com o sofrimento e não tem significado de desvalorização profissional, mas antes de queixa, de protesto silencioso.

\author{
Busca de outras oportunidades dentro do Tribunal - ou "articular", "circular", \\ "pular de lugar em lugar”, "ser político"
}

Significa obter melhor situação de trabalho, obter cargo comissionado ou função gratificada por meio do estabelecimento de relação pessoal com alguém na Instituição.

“Cada um tem a sua estratégia. Tem aqueles que articulam para conseguir um cargo e um melhor salário" (Entrevista 10)

Esta estratégia, em geral, é vista de forma depreciativa pelos entrevistados. Pô-la em prática, para os entrevistados, significa jogar segundo as regras informais de valorização das relações de apadrinhamento do serviço público, que são mal-vistas.

“Aí eu vou lá, nunca falei a não ser bom-dia pra você e eu vou lá pedir um cargo?... Isso pra mim é mendigar.” (Entrevista 10)

Esta estratégia é caracterizada da seguinte forma pelos entrevistados: o servidor abandonaria a expectativa do reconhecimento pelo trabalho e buscaria através de 
contatos informais e amizades a concessão de um cargo ou função gratificada, obtendo, por meio desta, status, melhor salário, crescimento profissional, ainda que temporários.

Esta estratégia também é utilizada por aqueles que, sentindo-se oprimidos em seus respectivos ambientes, buscam outra oportunidade dentro da instituição, ainda que não vinculada a cargo ou função gratificada. Neste caso, a conotação depreciativa não está presente.

Apesar de condenada no grupo, os entrevistados consideram-na a mais provável de lograr êxito. É tido que, aqueles que a utilizam estão sempre ocupando cargos e funções gratificadas.

\section{Estudar para prestar concursos para carreiras jurídicas}

(Promotoria, Procuradoria, Magistratura)

O desejo de tornar-se promotor, procurador ou magistrado foi mencionado por 52\% dos entrevistados. No entanto, um número menor do que este se mantém estudando, voltado sistematicamente para tal objetivo.

Isto se deve ao fato de esta opção encontrar-se fortemente vinculada à estrutura familiar e sócio-econômica da pessoa, exigindo da pessoa dedicação, esforço e abdicação do tempo livre para os estudos e, conseqüentemente, participação e suporte da família em tal empreendimento.

Esta situação está ligada, no discurso dos entrevistados, aos servidores com curso superior de Direito e em geral com possibilidades de dedicar-se aos estudos. Poder 
dedicar-se aos estudos, para os entrevistados, significa dispor de situação econômica familiar vantajosa no que diz respeito aos recursos financeiros e tempo disponíveis. Ou seja, os solteiros que não são principais provedores de um lar levam grande vantagem.

Grande parte, porém, permanece dedicando-se aos estudos, em busca de outras oportunidades via concursos públicos, mesmo que não para as carreiras apresentadas acima. A expectativa de ter um novo trabalho parece equivaler à esperança de livrar-se de aspectos indesejáveis do trabalho constitutivos de sofrimento.

$\underline{\text { Investir afetiva e intelectualmente em atividades extra-trabalho ou outros }}$ aspectos da vida (família, por exemplo)

Esta estratégia significa uma re-significação do trabalho na vida da pessoa e a priorização de outros aspectos.

É esperado que isto ocorra em determinadas fases da vida de uma pessoa. No entanto, algumas vezes, esta atitude é provocada por um sentimento de desesperança e frustração no trabalho, pelo qual a pessoa interrompe, na medida do possível, seu investimento no trabalho, para que frustrações subseqüentes não ocorram. Desta forma, busca investir em outros aspectos da sua vida, nos quais acredita obter um retorno.

É a partir deste raciocínio que os entrevistados relacionam esta estratégia com o sofrimento no trabalho. 
Planos familiares ou pessoais foram mencionados como importantes depositários dos esforços e atenções anteriormente direcionados ao trabalho. Como exemplo tem-se a chegada de um novo membro à família com a gravidez, o plano de montar um negócio próprio ou familiar, plano de mudar de área profissional.

\section{EXPRESSÕES DO SOFRIMENTO NO TRABALHO}

\section{Medo}

A condição de portador de um cargo ou função gratificada é, algumas vezes, geradora de medo, caso a pessoa encontre-se vulnerável a perda da mesma, na sua avaliação ou na do grupo com quem trabalha. É o medo da queda repentina do nível sócio-econômico.

“... Então, isso daí (a competição pelas verbas) faz com que a gente comece a ter medo das pessoas que trabalham do teu lado... você começa a se sentir como se estivesse vivendo uma guerra fria...” (Entrevista 12)

Também a condição de estar com uma grande carga de trabalho, normalmente com prazos a serem cumpridos, gera medo.

Além disso, a condição de estar se sentindo oprimido por superiores também gera medo. 


\section{Sentimentos de auto-desvalorização}

Tal sentimento encontra-se muito relacionado à própria representação do funcionário público na sociedade. O sentimento de autodesvalorização pode ser exemplificado por uma das falas:

“... eu acho que é a desvalorização que a imagem do funcionário público tem na sociedade. Você fala que você é funcionário público, o pessoal já lê na sua testa que você é vagabundo. Aí você chega aqui, tem um monte de serviço... E o funcionário acaba introjetando isso, ele acaba se achando uma porcaria, apesar de trabalhar muito, muitas vezes...”(Entrevista 21)

Além disso, o fato de haver sempre trabalho acumulado para ser feito, pelo volume cumulativo, faz com que o sentimento de impotência inicial acabe transformando-se em sentimento de incapacidade.

A forma com que são concedidas e retiradas as funções gratificadas e os cargos comissionados também gera sentimentos de autodesvalorização. 


\section{Desesperança, desalento, sentimentos negativos}

A frustração de expectativas, a vivência da injustiça no local de trabalho e a opressão por parte de superiores são relatadas como geradoras de sentimentos de raiva, mágoa, ressentimento, tristeza, revolta, indignação e vontade de vingar-se.

“... você vai pra casa pensando naquela pessoa, vai pensando as piores coisas, ... isso faz mal, ... fica uma raiva, um sentimento ruim dentro de você. Porque a pessoa está numa situação privilegiada e pensa que por causa disso pode fazer uso da superioridade”. (Entrevista 36)

Os servidores relatam ainda que essa exacerbação de sentimentos negativos pelas pessoas causa-lhes bastante incômodo.

A intensificação disto, na visão dos entrevistados, acaba por levar a um desestímulo, desmotivação, sendo descritas atitudes como “travar-se”, “emudecer”.

“As pessoas que se sentem injustiçadas ficam realmente muito infelizes, ... Isso reflete não só no ambiente de trabalho, mas também na família, a pessoa fica mais amarga, desiludida, deprimida”. (Entrevista 12) 


\section{Contaminação do pensamento e do sono por conteúdos do trabalho}

Foram relatadas dificuldades para relaxar após a jornada de trabalho, a noite e ainda quando o servidor se encontra em férias. O excesso de tensão no dia-a-dia prolonga-se para a vida fora do trabalho, fazendo com que, muitas vezes, a pessoa permaneça pensando nos problemas vivenciados no trabalho, durante o seu tempo de lazer e descanso.

Uma das entrevistadas relata que, ao sair de férias demora alguns dias para desligar-se do trabalho e aproveitar o período de férias.

A insônia também foi relatada como conseqüência do trabalho.

\section{Adoecimentos somato-psicológicos}

Um dos termos mais utilizados pelos entrevistados, quando falavam sobre as manifestações do sofrimento no trabalho, é stress. Descrevem a tensão, o enrijecimento dos músculos, dores de cabeça, problemas gastro-intestinais, músculo-esqueléticos como originados pelo stress do trabalho.

Foram relatados desgaste físico, esgotamento, cansaço, principalmente pelos servidores de subsecretarias, em que há uma carga de trabalho físico. Do âmbito mental, surgiram a depressão, o alcoolismo e o pânico como problemas relacionados ao trabalho, na visão dos entrevistados.

A depressão também foi citada pelos entrevistados, principalmente relacionada ao sentimento de estar sendo oprimido no ambiente de trabalho. 
As licenças e os afastamentos também foram lembrados como situações condicionadas ao sofrimento relacionado ao trabalho.

\subsection{Consolidação dos resultados}

As 37 pessoas entrevistadas foram convidadas à devolutiva, feita individualmente. Destas, 27 compareceram à entrevista devolutiva. Nesta entrevista, como a análise ainda estava em andamento, foi relatado um resumo dos resultados parciais, bem como discutidas as implicações de tal estudo. As pessoas manifestaram concordância com os resultados parciais apresentados - as unidades de registro ou frases modais, etapa anterior à categorização. Porém, no momento em que se discutiu as implicações, manifestavam descrença na possibilidade de mudança dos aspectos constitutivos do sofrimento. O questionamento sobre onde o trabalho seria publicado e apresentado, também ocorreu.

No I Fórum Psicossocial da Justiça Federal, a apresentação suscitou o debate sobre os limites de atuação da equipe de saúde e mesmo da presidência do Tribunal sobre estes aspectos estruturais do Poder Judiciário, determinantes do volume cumulativo de trabalho, da injustiça no trabalho, da estagnação profissional, por exemplo. Discutiu-se ainda a limitação de práticas de programas de qualidade de vida, para evidenciar tais aspectos e intervir sobre eles. 


\subsection{A Representação do Sofrimento no Trabalho à luz das Necessidades Humanas e das Expectativas Profissionais}

O conceito de necessidades humanas aqui adotado as pressupõem como objetivas e universais, tendo como bases as categorias saúde física e autonomia (DOYAL e GOUGH, 1991). Estes autores rejeitam as concepções naturalistas, relativistas e culturalistas das necessidades, sustentando que os homens, em qualquer tempo, lugar e cultura, têm estas duas necessidades básicas comuns (OLIVEIRA, 2001).

Assim, a privação da saúde e da autonomia traria sérios prejuízos à vida, ao bemestar e aos direitos morais. A autonomia é entendida, no contexto da teoria das necessidades humanas básicas, como a capacidade de eleger opções informadas sobre o que se tem que fazer e de como levá-las a cabo (DOYAL e GOUGH, 1991). Envolve ainda a possibilidade de participação crítica nos variados espaços sociais, significando capacidade de identificar, analisar e agir para a modificação da forma de vida na qual se insere socialmente (GOUGH, 2000).

Atendo-nos ao âmbito do trabalho, pode-se dizer que algumas categorias da representação do sofrimento no trabalho estão relacionadas à carência da possibilidade ou capacidade no exercício da autonomia no cotidiano de trabalho. Por exemplo, a falta de autonomia no trabalho, o volume cumulativo de trabalho sobre o qual o servidor vêse impotente e a opressão exercida por superiores. Assim, tais categorias estão relacionadas à privação de necessidades humanas básicas e representam um dano importante ao servidor. 
Tendo por base o contraponto que DOYAL e GOUGH (1991) fazem de necessidades para desejos e preferências, pode-se dizer que a expectativa encontra-se entre estas duas últimas. As expectativas variam e são determinadas tanto por aspectos individuais, como história de vida, particularidades quanto pelo contexto cultural em que está inserida a pessoa. Expectativa, no dicionário Novo Aurélio significa esperança fundada em supostos direitos, probabilidades ou promessas (FERREIRA, 2000). Para estes autores, a frustração de expectativas pode levar a sofrimento e a prejuízos de menor amplitude.

Algumas dimensões do sofrimento, tal como relatadas pelos entrevistados, mostravam-se relacionadas à frustração de sonhos e planos que as pessoas tinham em relação ao trabalho, ou seja, as expectativas profissionais.

Para uma população predominantemente de profissionais com curso superior, o trabalho, além de viabilizar a subsistência, é provedor de auto-estima, definidor do papel social e status. Na leitura das expectativas profissionais se evidencia tal afirmação. Há muito freqüentemente o desejo de crescimento, desenvolvimento e maiores ganhos. A freqüência com que aparece o desejo de ter uma carreira jurídica como Promotoria, Magistratura ou Procuradoria (tão valorizadas no campo profissional do Direito) e os sacrifícios auto-impostos para alcançá-las, também demonstram a importância do papel profissional na vida das pessoas.

A relação encontrada entre as expectativas profissionais e o sofrimento no trabalho foi de um ajustamento constante de uma à outra. Ou seja, primordialmente no momento do ingresso à instituição, esta serviu como depositária dos sonhos e planos ainda idealizados da pessoa, em relação à vida profissional numa instituição do Poder 
Judiciário. Mas, a medida em que a pessoa conhecia e explorava esta realidade, seja por meio da experiência própria, seja por meio da troca de experiências entre os colegas, ocorria um re-arranjo de suas expectativas frente à realidade percebida da instituição.

Foi freqüente o relato de que as expectativas despertadas pela realidade vivenciada no momento de ingresso no Poder Judiciário direcionam os projetos pessoais profissionais para o desejo de crescimento dentro dele, através dos cargos comissionados e funções gratificadas. Porém, a medida em que a convivência com a injustiça, com o não reconhecimento pelo trabalho desenvolvido, se aprofunda, pode haver um redirecionamento dos projetos profissionais das pessoas, seja no sentido de buscar caminhos alternativos, fora da Instituição, seja re-significando o trabalho em suas vidas, modificando os valores a ele associados ou colocando-o em segundo plano, ou mesmo “desinvestindo” seus esforços e direcionando-os para outros setores da vida. Estas são as estratégias construídas para lidar com a frustração e o sofrimento decorrente do trabalho.

Dentre os entrevistados, 86\% são bacharéis em Direito, ainda que destes, nem todos ocupem cargo correspondente ao nível universitário. Em geral, os bacharéis em Direito apresentam expectativas de desenvolvimento e crescimento profissional no campo jurídico, não desejando restringirem-se ao cargo atual de técnico ou analista judiciário. A estagnação profissional, enquanto categoria da representação do sofrimento no trabalho, mantém relação com a atitude de buscar oportunidades de ocupar cargos comissionados ou funções gratificadas dentro da própria instituição, ou de estudar duramente para concursos públicos a carreiras jurídicas.

Estas duas atitudes são formas encontradas para lidar com a estagnação profissional. 
Pela inconstância e vulnerabilidade das posições de quem ocupa cargos comissionados e funções gratificadas, a busca delas é um caminho que acaba por manter o servidor em constante pressão e vulnerabilidade em relação àqueles que exercem o poder da concessão e da exoneração.

Quanto a segunda alternativa, o alcance das carreiras jurídicas fica normalmente limitado àqueles que apresentam condições sociais, econômicas e familiares favoráveis ao estudo.

As carreiras de Promotoria, Procuradoria e Magistratura são idealizadas por grande parte dos entrevistados. Tais carreiras representam, para os entrevistados, a possibilidade de trabalhar com maior autonomia e valorização social e ainda a possibilidade de defender seus ideais de justiça. Cerca de 52\% afirmaram que gostariam de ingressar em tais carreiras, e cerca de 35\% encontra-se estudando e prestando concursos atualmente. Aqueles que tem a intenção de ingressar para a carreira jurídica afirmam serem necessárias de 4 a 6 horas diárias de estudo, durante um, dois ou mais anos.

Dentre os que estão satisfeitos com sua posição atual e pretendem manter-se nela, foram encontrados 2 diretores, 2 chefes de gabinete e 4 funcionários com função gratificada, totalizando $24 \%$ dos entrevistados.

Dois servidores buscam a oportunidade de vir a ocupar cargos de confiança, de chefe ou assessor. Para isso, entendem que devem contar com a capacidade de trabalho e com contatos pessoais dentro da instituição.

A espera da aposentadoria foi mencionada por 2 entrevistados, os quais pretendem investir em outra carreira não jurídica após se aposentarem. Uma pessoa 
pretende abandonar o Tribunal antes da aposentadoria, para trabalhar em outra área também não jurídica.

Uma pessoa pretende se desligar de cargo commissionado, mas manter-se como servidora. E uma delas relatou já ter se desligado de cargo em comissão por vontade própria. Tais desligamentos parciais são explicados pela condição de sobrecarga de dirigentes e pela dificuldade de relacionamento com os desembargadores.

Três pessoas não especificaram o que pretendem fazer, mas afirmaram desejar buscar experiências novas no futuro.

No entanto, a frustração não se fazia presente somente em relação às expectativas profissionais, mas, algumas vezes, esta frustração também se dava sobre aquilo que o servidor espera da atuação do Poder Judiciário, sobretudo no que tange à sua função principal e geral de distribuir a Justiça. Foi comum o relato de ter havido uma idealização da Justiça, enquanto Instituição de nossa sociedade no momento do ingresso para o trabalho nela. A inserção no Poder Judiciário faz-se acompanhada de uma introjeção dos valores de justiça e eqüidade social pelos futuros servidores. No entanto, posteriormente, na prática do trabalho, vêem-se cercados por processos, cada um representando uma reivindicação pela Justiça em nosso país. Estas reivindicações mostram-se impossíveis de serem atendidas, por causa da incompatibilidade entre a demanda e as condições estruturais do trabalho na justiça. Sentindo-se responsáveis pelo trabalho, os servidores sofrem por tal contradição. Embora não tenham sido entrevistados magistrados, pode-se suspeitar que tal questão também os atinge, talvez até de forma mais intensa. A expectativa existente em relação à Justiça relacionava-se à 
idéia de trabalhar pela distribuição da Justiça na sociedade, ideal possivelmente relacionado ao bacharelado em Direito. 


\subsection{O conhecimento do senso comum como um sistema de pensamento formador de significados em Saúde do Trabalhador}

O campo de saberes da Saúde do Trabalhador, circunscrito à Saúde Coletiva, é um campo interdisciplinar cuja abrangência extrapola as áreas do conhecimento habitualmente pertencentes ao âmbito da saúde (MINAYO-GOMEZ E THEDIMCOSTA, 1997), absorvendo e contemplando disciplinas das Ciências Humanas, Sociais e Econômicas. Diversos estudos disciplinares confluem para uma zona de empatia, contribuindo ao estudo da relação trabalho-saúde, ainda que esteja ausente a precisão conceitual de tal relação (MINAYO-GOMEZ e THEDIM-COSTA,1997). A Medicina do Trabalho e a Saúde Ocupacional apresentam insuficiência de um modelo de compreensão amplo desta relação. A partir desta insuficiência, diversas disciplinas do conhecimento vêm contribuindo, parcialmente, para o desenvolvimento de estudos voltados à compreensão da relação trabalho-saúde em diversos contextos de trabalho.

Uma contribuição da Psicologia Social é utilizada nesta dissertação, que é a adoção da Teoria das Representações Sociais como forma de abordagem do conhecimento prático do trabalho.

Por meio da identificação da representação social do sofrimento no trabalho buscou-se explorar a relação entre o trabalho e a saúde, privilegiando-se o conhecimento prático do trabalho.

A importância do conhecimento prático sobre a relação entre saúde e trabalho já foi evidenciada em várias vertentes ligadas ao campo da saúde do trabalho: a Medicina 
Social, a Ergonomia Francesa, a Psicologia Social e ainda o Modelo Operário Italiano (LAURELL e NORIEGA, 1989; DANIELLOU e cols, 1989; SATO, 1991).

SATO (1992) aponta para a carência de teorização sobre o conhecimento prático e a necessidade de resgatá-lo, de forma a explicitar sua lógica e reabilitá-lo ao debate construtivo com o conhecimento científico.

Segundo SATO (1992), a adoção da Teoria das Representações Sociais possibilita justamente o respeito à lógica própria do pensamento do senso comum, resgatando as categorias a partir do discurso coletivo, sem moldar seu conteúdo ao conhecimento científico.

As categorias interligadas e relacionadas ao sofrimento no trabalho pelos entrevistados são antes elementos de uma teoria que os guia no dia-a-dia do enfrentamento do contexto de trabalho, do que opiniões, imagens ou idéias. Estas últimas são dimensões das representações. Há uma teoria sobre a relação entre o trabalho e a saúde que explica e unifica as opiniões e atitudes em relação ao sofrimento. MOSCOVICI e MARKOVÁ (1998) apontam este como um ponto fundamental da Teoria das Representações Sociais, a de que, a partir da constatação de que um objeto esteja presente no cotidiano de um grupo e que seja importante para este grupo, há uma teoria que orienta a ação e o pensamento em relação àquele objeto. Nomear teoria significa dizer que há um conhecimento que possui uma lógica e que esta pode ser apreendida. Significa dizer ainda, que há hipóteses sobre a forma como o trabalho afeta a saúde e sobre o papel da experiência subjetiva do sofrimento no trabalho nesta relação. Estas hipóteses estão implícitas nas atitudes, no trabalho, nas ações planejadas, individual ou coletivamente, e nas opiniões sobre o trabalho e a saúde. Estão baseadas 
em um corpo de conhecimentos estruturados logicamente, a partir do contato com as informações circulantes na sociedade sobre o tema, a partir da experiência própria no cotidiano de trabalho e ainda a partir da troca de experiências por meio do diálogo com os colegas de trabalho.

Retomando ROUQUETTE (1998), as práticas são uma determinação objetiva das representações, enquanto estas exercem uma coerção variável e não uma determinação propriamente dita. Esta consideração oferece elementos para a compreensão do movimento pelo qual as práticas existentes na instituição determinam a representação do sofrimento no trabalho e do próprio trabalho. E, ao mesmo tempo, as expectativas antes existentes e as ações relacionadas ao papel e ao futuro profissional vão sendo modificadas conforme se modificam as representações.

Desta forma explica-se o título deste capítulo, inspirado em uma das qualidades do conhecimento prático em saúde do trabalhador, que é a criação de significados, segundo SATO (1992). A outra qualidade é constituir-se enquanto fonte de informações.

Como fonte de informações, foram encontrados pontos de tangência e concordância do conhecimento prático de servidores a respeito dos elementos constitutivos do sofrimento no trabalho com dados originários de estudos baseados na análise de estudiosos do Poder Judiciário e magistrados sobre os principais problemas que compõem a “Crise do Judiciário”. Dentre eles, o formalismo, a demanda crescente e incompatível com a estrutura hoje existente e com o número de servidores, a centralização administrativa nos magistrados, a ausência de plano de carreiras.

Além dos pontos de tangência, o conhecimento do senso comum permitiu um aprofundamento na compreensão das repercussões na vida dos servidores advindas de 
características da organização do trabalho, das políticas de gestão de servidores no funcionalismo público brasileiro e da própria natureza do trabalho no Poder Judiciário. Um ciclo danoso tanto para a eficiência do trabalho quanto para a vida e saúde dos servidores surge e é alimentado a partir de normas e procedimentos formais e informais que significam, para os servidores, a injustiça, o não reconhecimento pelo trabalho e o não respeito pelo servidor, do ponto de vista do seu papel profissional.

Retomando FRANÇA (1993), que salienta a importância de se considerar o grupo de servidores públicos como um grupo heterogêneo, tendo em seu interior também uma estrutura de classes sociais, mostra-se que os diferentes subgrupos de entrevistados (tendo como critério a posse de cargo comissionado ou função gratificada: servidores com função gratificada, servidores com cargo comissionado, servidores sem função gratificada ou cargo comissionado; tendo como critério o cargo ocupado: técnicos judiciários, analistas judiciários, chefes de gabinete, diretores de subsecretarias; tendo como critério o setor: gabinete, subsecretaria) compartilham de uma teoria comum a respeito do sofrimento no trabalho. Eles apontam os mesmos elementos do trabalho como constitutivos do sofrimento, percebem de forma semelhante o mecanismo pelo qual se estabelece uma espécie de moderação do sofrimento e concordam na compreensão sobre a forma pela qual este sofrimento mantém uma relação com a forma de significar o trabalho e seu papel na vida das pessoas e ainda como este sofrimento se manifesta no indivíduo.

O fato de compartilharem o mesmo contexto de trabalho é significativo na formação da representação sobre o sofrimento no trabalho. 
O conhecimento prático do trabalho mostrou ser de extrema relevância para os interesses de planejamento de ações de promoção de saúde dos servidores, qualidade de vida no trabalho e mesmo para o planejamentos de mudanças estruturais voltadas ao aprimoramento dos serviços prestados, da eficiência e funcionalidade de um órgão público ou empresa. Considerar este conhecimento enquanto válido, é resgatá-lo para um diálogo com conhecimentos de outra natureza, por exemplo, o conhecimento científico.

O empecilho à efetiva participação dos trabalhadores na determinação de questões relacionadas à organização do trabalho que desenvolvem e ainda de questões do trabalho que possam interferir na saúde e bem-estar dos próprios está antes no conflito de interesses entre os diferentes grupos que constituem uma instituição e na centralização do poder do que nas divergências entre o conhecimento científico e o saber prático. No contexto de conflitos de interesses, o conhecimento científico exerce muitas vezes o papel de instrumento de legitimação de interesses do poder dominante. Assim, nesta condição, as práticas voltadas à promoção da saúde e à qualidade de vida restringem seu foco aos indivíduos, mantendo intactas a organização do trabalho e condições de trabalho. LACAZ (2000) defende que a condição para uma real intervenção em qualidade de vida no trabalho é o estabelecimento de canais coletivos de negociação, com participação efetiva de todos aqueles envolvidos no processo de trabalho.

PARAGUAY (2003) salienta que analisar e intervir em aspectos da organização do trabalho, tendo como norte a saúde ou o trabalho, implica primeiramente desvelar a concepção de homem e de trabalho implícitas e os impactos desta relação, pela 
compreensão do trabalho real. Para tal feito, é necessária a conjugação de saberes de todos os envolvidos, e não apenas os especialistas ou a hierarquia (PARAGUAY, 2003). 


\section{CONSIDERAÇÕES FINAIS}

A principal contribuição deste estudo é reforçar e demonstrar a importância do saber prático dos servidores para a análise das formas de organização do trabalho, das políticas de gestão de pessoas no serviço público e o impacto de ambos na saúde. Este estudo deteve-se ao saber dos servidores no contexto do Poder Judiciário, não só como fonte de informações, mas como criador de significados a respeito da relação saúdetrabalho.

Embora a instituição seja vista pela maioria dos entrevistados como imutável, viu-se que as pessoas operam mudanças constantes dentro de seu campo de ação para driblar uma condição de insatisfação, para conseguir algo almejado, para executar o trabalho da melhor forma dentro de condições muitas vezes inadequadas. No entanto, o planejamento do trabalho acaba por ignorar este conhecimento prático que faz com que as coisas aconteçam no dia-a-dia.

Promover um ambiente de trabalho saudável significa considerar o trabalho em sua relação com as necessidades e as expectativas dos trabalhadores, para respeitá-las. Significa planejar ou re-planejar o trabalho levando em conta, dialogicamente, estas necessidades e expectativas.

As práticas voltadas à promoção de saúde devem levar em conta este conhecimento, pautado na subjetividade, se estas práticas são pretendidas enquanto efetivas melhorias das condições de trabalho e, portanto, de saúde. 
Ao mesmo tempo em que os servidores sentem a frustração de suas expectativas e necessidades, o contexto social de crise de emprego coloca-os em um dilema: estão insatisfeitos, mas é cada vez mais difícil abrir mão do trabalho atual para buscar outro. Percebem-se confinados no serviço público.

Adicionalmente, dentro das instituições públicas, as políticas de remuneração acabam desempenhando um papel de controle perverso sobre o quadro de servidores.

A incapacidade de mudar, que é tratada na literatura judiciária como um dos maiores problemas do Poder Judiciário e que foi inúmeras vezes citada e exemplificada pelas pessoas entrevistadas, também contribui, juntamente com o confinamento no emprego, para a exacerbação desse sofrimento.

Embora o estudo tenha sido feito com servidores da justiça, tendo-se limitado ao contexto de trabalho de um Tribunal Judiciário Federal, pode-se aventar a hipótese de que os elementos formadores da representação social do sofrimento no trabalho apurados neste estudo guardem estreita relação com o serviço público em geral, não sendo exclusivos das instituições do Poder Judiciário. 


\title{
REFERÊNCIAS BIBLIOGRÁFICAS
}

Acco MAC, Bernardes F, Moura MG - Diagnóstico da situação da mulher na Administração Pública Federal. Pesquisa ENAP. Mimeo; 1998

\begin{abstract}
Alonso M - Custos no serviço público. Rev Serv Públ (Brasília)1999 Jan/Mar; 50(1): 37-62.
\end{abstract}

Aragão CV - Fatores agilizadores e restritivos à atuação da Justiça do Trabalho: um estudo exploratório. Rev Adm Pública (Rio de Janeiro) 1997 Jul/Ago; 31(4): 183-215.

Assunção AA, Lima FPA, Lima MEA - Avaliação das condições ergonômicas e psicossociais de trabalho no Tribunal de Justiça - MG. - Relatório final. Belo Horizonte: mimeo; 1998.

Bardin L - Análise de conteúdo. Lisboa: edições 70; 1988.

Bellusci SM - Envelhecimento e condições de trabalho em servidores de uma instituição judiciária - Tribunal Regional Federal da $3^{\mathbf{a}}$ região. São Paulo; 1998. [Dissertação de Mestrado - Faculdade de Saúde Pública da USP].

Bourdieu P - Compreender. In: Bourdieu P (coord) - A miséria do mundo. $3^{\text {a }}$ edição. Petrópolis: Vozes; 1999.

Brasil. Constituição da República Federativa do Brasil. São Paulo: IMESP; 1988. 
Brasil. Regime jurídico dos servidores públicos civis da União, das autarquias e das fundações públicas federais, lei n. 8112 de 11 de dezembro de 1990. $2^{\text {a }}$ ed. São Paulo: Saraiva; 1992.

Brito WB de - A Justiça Federal: Análise da imagem institucional. In: Conselho da Justiça Federal / Centro de Estudos Jurídicos - A Justiça Federal: Análise da imagem institucional. Brasília: CJF; 1995.

Britten N - Qualitative interviews in health research. In: Pope C e Mays N - Qualitative Research in Health Care. London: BMJ Books; 2000. Disponível em : URL: http://www.bmjbooks.com

Carone I - A questão dos paradigmas nas ciências humanas e o paradigma da estrutura das objetivações sociais de Agnes Heller. In: Lane STM e Sawaia BB (orgs.) - Novas veredas da psicologia social. São Paulo: Educ/Brasiliense; 1994.

Chanlat F - Modos de gestão, saúde e segurança no trabalho. In: Davel EPB e Vasconcelos JGM - Recursos Humanos e Subjetividade. Petrópolis: Vozes; 1996.

Conselho da Justiça Federal - Tabela de vencimentos dos servidores das carreiras do Poder Judiciário. Vigência 01/01/2000.

Cordeiro AN, Garbin AC, Guidorizzi CJ, Machado SC, Tavares DS, Sola ER, Ribeiro IP - As condições de trabalho em um órgão do Poder Judiciário Federal. SP: CEREST/SP, mimeo 2000.

Dallari AA - O que é funcionário público. São Paulo: Brasiliense; 1989. 
Dallari DA - O Poder dos Juízes. São Paulo: Saraiva; 1996.

Daniellou F, Laville A e Teiger C - Ficção e realidade do trabalho operário. Rev Bras Saúde Ocup 1989; 68(17): 7-13.

Dejours C - Por um novo conceito de saúde. Rev Bras Saúde Ocup 1986; 54(14): 7-11.

Doyal L e Gough I - A theory of human needs. MacMillan; 1991.

Durand JC e Beltrão VER - Recensear funcionários públicos: uma necessidade. Rev Serv Públ 1994; 118(2): 185-198.

Farr RM - Representações sociais: a teoria e sua história. In: Guareschi P e Jovchelovitch S - Textos em Representações Sociais. Petrópolis: Vozes; 1994.

Farr RM - As raízes da Psicologia Social Moderna. 3a edição. São Paulo: Vozes; 2000.

Ferreira ABH - Novo Aurélio: o Dicionário da Língua Portuguesa - século XXI. Nova Fronteira e Lexikon Informática [versão on line]; 2000. Disponível em < URL: http:॥www.uol.com.br/aurelio.

França BH - O Barnabé: consciência política do pequeno funcionário público. São Paulo: Cortez; 1993.

França BH - Funcionário público: trabalhador como os outros? Rev Serv Públ (Brasília) 1994; 118(2): 199-212. 
Führer MCA - Resumo de Processo Civil. 20ª ed. São Paulo: Malheiros; 1999.

Garbin AC e Tavares DS - A Relação Saúde Mental e Trabalho dos funcionários públicos do Setor Judiciário. Anais do VI Congresso Brasileiro de Saúde Coletiva: Sujeito Ação em Saúde Coletiva. 2000 ago 28 - set 01; Salvador Bahia. São Paulo: ABRASCO; 2000. Vol 5 - Supl 2000, p.513.

Gough I - Global Capital, Human Needs and Social Policies - selected essays, 19941999. Palgrave; 2000.

Heller A, Fehér F - A condição política pós-moderna. Rio de Janeiro: Civilização Brasileira; 1998.

Heller A - O Cotidiano e a História. São Paulo: Paz e Terra; 1972.

Herzlich C - A problemática da representação social e sua utilidade no campo da doença. Physis (Rio J) 1991; 1(2): 23-36.

Hirigoyen MF - Assédio moral: a violência perversa no cotidiano. Rio de Janeiro: Bertrand Brasil; 2000.

Hirigoyen MF - Mal-estar no trabalho: redefinindo o assédio moral. Rio de Janeiro: Bertrand Brasil; 2002.

Hogarth F - Glossary of Health Care Terminology. Copenhagen: WHO; 1975.

Jodelet D - La representación social: fenómenos, concepto y teoria. In: Moscovici S Psicología Social II: Pensamiento y vida social, psicología social y problemas sociales. Barcelona: Paidós; 1984. 
Kfouri BMB - Carreiras gerenciais no serviço público: caminhos num espaço sem caminhos. São Paulo; 1992. [Dissertação de mestrado - Escola de Administração de Empresas da Fundação Getúlio Vargas].

Lacaz FAC - Qualidade de vida no trabalho e saúde/doença. Ciênc Saúde Coletiva 2000; 5(1): 151-161.

Laurell AC, Noriega M - Processo de produção e saúde - trabalho e desgaste operário. São Paulo: Hucitec; 1989.

Minayo-Gomez C, Thedim-Costa SMF - A construção do campo da saúde do trabalhador: percurso e dilemas. Cad Saúde Pública 1997; 13(supl.2): 21-32.

Morin EM - Os sentidos do trabalho. Rev Administração Emp 2001; 41(3): 8-19.

Moscovici S - A Representação Social da Psicanálise. Rio de Janeiro: Zahar; 1978.

Moscovici S e Marková I - Presenting Social Representations: A Conversation. Culture \& Psychology 1998; 4(3): 371-410.

Oliveira DC - O desenvolvimento infantil e suas representações: dimensões do saber técnico-profissional e do senso comum. São Paulo, 1991 [Dissertação de Mestrado Faculdade de Saúde Pública da Universidade de São Paulo]. 
Oliveira DC - Práticas sociais em saúde: uma releitura à luz da Teoria das Representações Sociais. In: Moreira ASP, Oliveira, DC (orgs) - Estudos Interdisciplinares de Representação Social. Goiânia: AB editora; 1998.

Oliveira DC - Representações Sociais e Saúde Pública: a subjetividade como partícipe do cotidiano. Revista de Ciências Humanas. 2000; Edição Especial Temática: Representações Sociais e Interdisciplinaridade (47-65).

Oliveira DC - A enfermagem e as necessidades humanas básicas: o saber/fazer a partir das representações sociais. Rio de Janeiro; 2001. [Tese de Professor Titular Faculdade de Enfermagem da Universidade do Estado do Rio de Janeiro].

Paraguay AIBB, Tavares DS - Sondagem preliminar sobre a percepção da relação saúde e trabalho no Tribunal Regional Federal da $3^{a}$ região. Projeto de Pesquisa CGIO (Concepção, Gestão e Inovação Organizacional), mimeo.; 2000.

Paraguay AIBB - Psychosocial Factors at Field Work - on the importance of negotiation and action in psychosocial factors at work. In: ICOH ' 2000 - 26th International Congress on Occupational Health; 2000; Singapore. Singapore; 2000,.v.1, p.264.

Paraguay AIBB - Da organização do trabalho e seus impactos sobre a saúde dos trabalhadores. In: Mendes R (org) - Patologia do Trabalho. 2a edição. São Paulo: Atheneu, 2003.

Rigamonte RC - O funcionário público do Poder Judiciário: a preservação da saúde frente às adversidades no contexto de trabalho. Belo Horizonte; 1998.[Dissertação de Mestrado - CEPEAD - Centro de Pós-Graduação e Pesquisas em Administração da Universidade Federal de Minas Gerais] 
Rouquette ML - Representações Sociais e Práticas Sociais: alguns elementos teóricos. In: Moreira ASP, Oliveira, DC (orgs) - Estudos Interdisciplinares de Representação Social. Goiânia: AB; 1998.

Sá CP de - A Construção do Objeto de Pesquisa em Representações Sociais. Rio de Janeiro: UERJ; 1998.

Sadek MT - A organização do Poder Judiciário no Brasil. In: Sadek MT (org) - Uma introdução ao estudo da Justiça. São Paulo: Idesp/Sumaré; 1995.

Sadek MT - Observações sobre a pesquisa. In: Sadek MT (org) - Uma introdução ao estudo da Justiça. São Paulo: Idesp/Sumaré; 1995.

Sadek MT, Arantes RB - A crise do Judiciário e a visão dos juízes. In: Revista USP Dossiê Judiciário. n²1; 1994.

Sato L - Abordagem psicossocial do trabalho penoso: estudo de caso de motoristas de ônibus. São Paulo; 1991. [Dissertação de Mestrado - Pontifície Universidade Católica].

Sato L - O psicólogo e a saúde do trabalhador na área sindical. In: Campos FCB (org) Psicologia e saúde: repensando práticas. São Paulo: Hucitec; 1992.

Sato L - A representação social do trabalho penoso. In: Spink MJ (org) - O conhecimento no cotidiano: as representações sociais na perspectiva da psicologia social. São Paulo: Brasiliense; 1993. 
Sato L - O conhecimento do trabalhador e a teoria das representações sociais. In: Codo W e Sampaio JC (orgs.) - Sofrimento psíquico nas organizações: saúde mental e trabalho. Petrópolis: Vozes; 1995.

Sato L - Prevenção de agravos à saúde do trabalhador: replanejando o trabalho através das negociações cotidianas. Cad Saúde Pública [periódico on line] set/out 2002; 18(5). Disponível em < URL: http: // www.scielo.br / scielo.php?script=sciarttext\&pid= S0102-

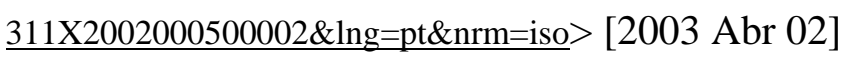

Sawaia BB - Psicologia Social: aspectos epistemológicos e éticos. In: Lane STM, Sawaia BB (orgs.) - Novas Veredas da Psicologia Social. SP: Educ/Brasiliense; 1994. (a)

Sawaia BB - Dimensão ético-afetiva do adoecer da classe trabalhadora. In: Lane STM, Sawaia BB (orgs.) - Novas Veredas da Psicologia Social. SP: Educ/Brasiliense; 1994. (b)

Sawaia BB - Análise psicossocial do processo saúde-doença. Rev Esc Enf USP, São Paulo, 28(1): 96-104; 1994. (c)

Sousa Santos B - Um discurso sobre as ciências. $12^{\text {a }}$ edição. Porto: Afrontamento; 2001.

Spink PK - A organização como fenômeno psicossocial: notas para uma redefinição da psicologia do trabalho. Psicologia e Sociedade 1996; 8(1): 174-192. 
Vala J - A Análise de Conteúdo. In: Silva AS, Pinto JM (orgs.) - Metodologia das Ciências Sociais. Porto: Afrontamento, 1986.

Veneu MG - Representações do funcionário público. Rev Adm Pública (Rio de Janeiro) 1989/1990; 24(1): 5-16.

Wagner W - Sócio-gênese e característica das representações sociais. In: Moreira ASP, Oliveira, DC (orgs) - Estudos Interdisciplinares de Representação Social. Goiânia: AB; 1998. 


\section{ANEXO 1 - ROTEIRO DE ENTREVISTA INDIVIDUAL DA ETAPA EXPLORATÓRIA}

Sexo

Escolaridade/Formação

Histórico ocupacional

Tempo de trabalho no Poder Judiciário

Cargo ocupado atualmente. Cargos anteriores na Instituição. Locais anteriores.

Cargos comissionados.

Duração atual da jornada de trabalho. Horário de trabalho. Pausas.

Dia-a-dia de trabalho. Atividades desenvolvidas.

Carga de trabalho. Como é distribuída no decorrer do dia e como é determinada.

Existência de prazos para cumprimento de tarefas.

Dificuldades enfrentadas na realização do trabalho.

Exemplos de situações identificadas como desgastantes, causadoras de sofrimento e insatisfação.

Vantagens e desvantagens identificadas em trabalhar nesta instituição.

Perspectivas profissionais no ingresso e atualmente, frente às possibilidades vislumbradas na instituição.

Forma como vê a influência do trabalho na saúde.

Quando se identifica algum fator problemático nas condições de trabalho, o que se faz? Tomar algum exemplo.

Qual é o papel de cada um (chefia, funcionário, desembargador) neste caso?

A quem cabe comunicar sobre tais questões? 


\section{ANEXO 2 - TERMO DE CONSENTIMENTO REFERENTE À OBSERVAÇÃO NO LOCAL DE TRABALHO}

Este termo refere-se ao consentimento do dirigente do setor para que se realize observação no local de trabalho para compreender organização do trabalho, com finalidade exclusiva de pesquisa.

\section{Sobre a Pesquisa:}

Esta pesquisa intitulada - “O contexto de trabalho em uma instituição do Poder Judiciário: uma análise psicossocial” - visa identificar aspectos positivos e negativos do contexto de trabalho para a manutenção e promoção da saúde e bem-estar das pessoas que dele fazem parte.

Partimos do pressuposto de que o conhecimento daqueles que vivenciam as situações cotidianas de trabalho pode trazer valiosos elementos para a compreensão da relação saúdetrabalho numa dada instituição. Assim, os aspectos positivos e negativos do trabalho em relação à saúde serão identificados a partir de dados coletados em entrevistas e observação dos ambientes de trabalho, salientando-se que o foco é o trabalho e sua forma real de organização e realização. Estas atividades serão desenvolvidas no período de julho a dezembro de 2001.

\section{É assegurado a todas as pessoas do local de trabalho observado:}

- O direito de ser informado sobre os objetivos e resultados do estudo;

- O acesso ao material de anotação da pesquisadora, caso o entrevistado queira;

- A total confidencialidade, sigilo e privacidade dos dados, sendo que, na apresentação dos resultados, não será possível a identificação de pessoas ou grupos da instituição.

Responsável: Psicóloga Daniela Sanches Tavares (tel cel [11] 9764 1706)

Orientadora: Profa. Dra. Ana Isabel B. B. Paraguay (tel com [11] 3066 7722)

Assinatura da pesquisadora Psicóloga Daniela Sanches Tavares

$\mathrm{Eu}$, declaro consentir que a pesquisadora realize observação no local de trabalho, com fins de pesquisa, mediante explicação dos objetivos da pesquisa e condições acima citados. 
Anexo 3 - Mapa de associação de idéias - Sofrimento no Trabalho - Etapa exploratória 


\section{ANEXO 4 - DADOS DE CARACTERIZAÇÃO DOS SETORES DE ESTUDO COLETADOS NA VISITA INICIAL}

\section{Gabinetes}

Número de servidores

Cargos

Funções

Número de processos

Tipos de processos existentes

Número médio de processo julgados mensalmente

Idade do gabinete

Fluxo de trabalho (fluxo de um processo no gabinete)

Entrada, processamento, prioridades, etapas

Divisão de tarefas entre as pessoas (quem faz o quê)

Recebimento, análise, pauta, tipos de processo, níveis de dificuldade, preparativos para sessão, revisão, formação de modelos-padrão

Tipos de variações periódicas na quantidade de trabalho

\section{Subsecretarias}

Número de servidores:

Cargos:

Funções:

Número de processos:

Tipos de processos existentes:

Atribuição de atividades por divisão

Descrição de tarefas

Tipos de atividades, prazos, existência de rodízio

Atendimento ao balcão 


\section{ANEXO 5 - ROTEIRO DE ENTREVISTA INDIVIDUAL}

Sexo

Escolaridade/Formação

Histórico profissional

Tempo de trabalho no Poder Judiciário

Cargo ocupado atualmente. Cargos anteriores na Instituição. Locais anteriores.

Cargos comissionados.

Dia-a-dia de trabalho. Atividades desenvolvidas.

\section{REPRESENTAÇÕES SOBRE O SOFRIMENTO NO TRABALHO.}

\section{FORMA COMO VÊ A RELAÇÃO ENTRE O TRABALHO E SOFRIMENTO}

Sofrer no trabalho ou pelo trabalho

Forma como vê o trabalho contribuindo ou causando sofrimento.

$O$ que faz com que se sofra no trabalho

EXEMPLOS DE SITUAÇÕES IDENTIFICADAS COMO DESGASTANTES, CAUSADORAS DE SOFRIMENTO E INSATISFAÇÃO.

Quais são as situações. Como são produzidas. O que determina o grau de sofrimento(sofrer mais ou menos). Formas de enfrentar (amenizando ou agravando).

Vantagens e desvantagens identificadas em trabalhar nesta instituição.

Perspectivas profissionais no ingresso e atualmente, frente às possibilidades vislumbradas na instituição. 


\section{ANEXO 6 - TERMO DE CONSENTIMENTO REFERENTE À ENTREVISTA}

Este termo refere-se ao consentimento individual do entrevistado para que sua fala seja gravada, transcrita e analisada, com finalidade exclusiva de pesquisa.

\section{Sobre a Pesquisa:}

Esta pesquisa intitulada - "O contexto de trabalho em uma instituição do Poder Judiciário: uma análise psicossocial” - visa identificar aspectos positivos e negativos do contexto de trabalho para a manutenção e promoção da saúde e bem-estar das pessoas que dele fazem parte.

Partimos do pressuposto de que o conhecimento daqueles que vivenciam as situações cotidianas de trabalho pode trazer valiosos elementos para a compreensão da relação saúdetrabalho numa dada instituição. Assim, os aspectos positivos e negativos do trabalho em relação à saúde serão identificados a partir de dados coletados em entrevistas e observação dos ambientes de trabalho, salientando-se que o foco é o trabalho e sua forma real de organização e realização. Estas atividades serão desenvolvidas no período de julho a dezembro de 2001.

\section{É assegurado aos participantes:}

- O direito de ser informado sobre os objetivos e resultados do estudo;

- O acesso ao material gravado e possibilidade de censurar partes da gravação, caso o entrevistado queira;

- A liberdade para retirar seu consentimento, desde que manifeste-se até o fim da entrevista;

- A total confidencialidade, sigilo e privacidade dos dados, sendo que, na apresentação dos resultados, não será possível a identificação de pessoas ou grupos da instituição.

Responsável: Psicóloga Daniela Sanches Tavares (tel cel [11] 9764 1706)

Orientadora: Profa. Dra. Ana Isabel B. B. Paraguay (tel com [11] 3066 7722)

Assinatura da pesquisadora Psicóloga Daniela Sanches Tavares

$\mathrm{Eu}$, declaro aceitar conceder entrevista de livre e espontânea vontade e consinto que os dados coletados na entrevista sejam utilizados com fins de pesquisa, mediante explicação dos objetivos da pesquisa e condições acima citados. 